\title{
Limonoids From the Genus Melia (Meliaceae): Phytochemistry, Synthesis, Bioactivities, Pharmacokinetics, and Toxicology
}

\section{OPEN ACCESS}

Edited by:

Lyndy Joy McGaw,

University of Pretoria, South Africa

Reviewed by:

Guozheng Huang,

Anhui University of Technology, China

Jung Chao,

China Medical University, Taiwan

Chengjian Zheng,

Second Military Medical University,

China

*Correspondence:

Zhengtao Wang

ztwang@shutcm.edu.cn

Li Yang

y17@shutcm.edu.cn

Specialty section:

This article was submitted to

Ethnopharmacology,

a section of the journal

Frontiers in Pharmacology

Received: 15 October 2021 Accepted: 06 December 2021

Published: 24 January 2022

Citation:

Fan W, Fan L, Wang Z and Yang L (2022) Limonoids From the Genus Melia (Meliaceae): Phytochemistry,

Synthesis, Bioactivities,

Pharmacokinetics, and Toxicology.

Front. Pharmacol. 12:795565.

doi: 10.3389/fphar.2021.795565

\author{
Wenxiang Fan ${ }^{1}$, Linhong Fan ${ }^{1}$, Zhengtao Wang ${ }^{1 *}$ and Li Yang ${ }^{1,2 *}$ \\ ${ }^{1}$ The MOE Key Laboratory of Standardization of Chinese Medicines, Shanghai Key Laboratory of Compound Chinese Medicines, \\ and SATCM Key Laboratory of New Resources and Quality Evaluation of Chinese Medicines, Institute of Chinese Materia Medica, \\ Shanghai University of Traditional Chinese Medicine, Shanghai, China, ${ }^{2}$ Shanghai Frontiers Science Center of TCM Chemical \\ Biology, Institute of Interdisciplinary Integrative Medicine Research, Shanghai University of Traditional Chinese Medicine, \\ Shanghai, China
}

Limonoids, as the vital bioactive chemical compounds in genus Melia plants, have attracted significant attention owing to their exclusive structural characteristics and remarkable biological activity. These compounds can be usually classified into two categories, including the ring-intact group and the ring-C-seco group. Benefiting from the development of separation and analysis technology, more than 200 limonoids have been isolated and identified from this genus. There is growing evidence that limonoids from genus Melia possess diverse pharmacological activities, especially anti-cancer effects, insecticidal activities, and anti-botulism effects. Toosendanin, one of the paramount limonoids, was considered as the pivotal bioactive marker in two medicinal herbs, including Melia toosendan Sieb. et Zucc and Melia azedarach L. In particular, limonoids are found to exhibit non-negligible toxic effects, a finding which needs further research. Besides this, the lack of clinical research data seriously hinders its further development and utilization, and necessary clinical trials should be taken into consideration. In this review, we systematically summarized the phytochemical compounds and their synthesis methods, pharmacological activities, and the structure-activity relationship, pharmacokinetics, and toxicology of genus Melia-derived limonoids. We believe that this up-to-date review could provide scientific evidence for the application of limonoids as agents beneficial to health in future clinical practice.

Keywords: limonoids, genus Melia, toosendanin, anti-tumor, insecticide, toxicology

\section{INTRODUCTION}

Genus Melia, a model genus of Meliaceae, has about 20 species in the world and is widely distributed in tropical and subtropical regions of the Eastern Hemisphere. Among them, Melia toosendan Sieb. et Zucc., Melia azedarach L., Melia azedarach var. japonica, and Melia volkensii Gürke have received a lot of attention (Liu et al., 2010). It is worth noting that Azadirachta indica A. Juss., a plant of the genus Azadirachta, is often wrongly recognized as $M$. azedarach L. for their similar morphological characteristics and botanical name (Saleem et al., 2018). Owing to their multiple bioactivities, the Melia plants have been used as folk herbs in treating leprosy, eczema, asthma, malaria, fever, and pain (Xie 
et al., 2008). M. toosendan Sieb. et Zucc and M. azedarach L., two common medicinal plants in China, have been used to treat diseases for thousands of years. The first traditional usage can be traced back to Shen Nong Ben Cao Jing, which is the earliest medical monograph in China that was written during the Eastern Han Dynasty (AD 25-220). In this monograph, the two herbs functioned as treatment for anxiety, destroying parasites, and promoting diuresis. According to Ben Cao Gang Mu (AD 1578), which is another famous medical classic, $M$. toosendan and $M$. azedarach could treat stomach ache and hernia. In addition, the ability to clear heat and promote diuresis was reported in Ben Cao Jing Shu (AD 1625). According to Chinese Pharmacopoeia, M. toosendan and M. azedarach have been recorded as insecticide and painkiller (Chinese Pharmacopoeia Commission, 2020). Various types of chemical compounds have been isolated and identified from different parts of genus Melia plants, including limonoids (triterpenoids), steroids, alkaloids, flavonoids, anthraquinones, etc. (Zhao et al., 2010). Modern pharmacological research demonstrated that limonoids, which are abundant in Melia species, exhibit a potential activity (Taylor, 1984). The word "limonoids" originated from the bitterness of lemon or other citrus fruits. Early chemical research of such compounds in Meliaceae started in 1960. The first limonoid compound named gedunin was isolated from wood of the West African plant Entandrophragma angolense, and its chemical structure was identified by comparison with limonin (Goerlich, 1960). The fundamental structure of limonoids is formed by the loss of four terminal carbons of the side chain in the apotirucallane or apoeuphane skeleton and then cyclized to form the $17 \beta$-furan ring, and thus limonoids are also known as tetranortriterpenoids (Tan and Luo, 2011). In this paper, a literature survey was carried out by searching the keywords including "limonoids", "Melia", "Melia toosendan Sieb. et Zucc", and "Melia azedarach L." from Pubmed, SciFinder, Science Direct, Scopus, the Web of Science, Google Scholar, China National Knowledge Infrastructure, and classic books of herbal medicine. All data were searched up to May 2021 to identify eligible studies. Some previous reviews have summarized the limonoids-related research progresses-for instance, the chemical compounds of Melia species and their bioactivities were summarized in 2010 (Zhao et al., 2010). In addition, a fantastic review has comprehensively covered the limonoids from Meliaceae, and their pharmacological effects were also concluded (Tan and Luo, 2011). Nevertheless, our work attempts to offer some constructive information that is favorable to the development of genus Melia-derived limonoids that originated from traditional medicinal herbs. Herein we systematically summarize the phytochemistry, synthesis, pharmacological activities, structure-activity relationships, pharmacokinetics, and safety aspects of limonoids, hoping that these could propel forward the exploration for this kind of valuable compound. Furthermore, the future research perspectives and difficulties are discussed as well.

\section{CHEMICAL COMPOUNDS}

After years of phytochemical research, more than 200 limonoids have been isolated and identified from genus Melia plants. As expected, the majority of these compounds originated from $M$. toosendan and $M$. azedarach because these two species are commonly used as medicinal herbs. In addition, the distribution of these compounds also varied in different parts of the plants, of which the fruit, bark, and root bark possessed higher content. Interestingly, those parts mentioned above are consistent with the medicinal parts of $M$. toosendan and $M$. azedarach. Therefore, isolation of bioactive compounds from medicinal herbs is a promising strategy for discovering lead compounds in drug development. At present, it is generally acknowledged that the precursors for the biogenic synthesis of limonoids are two types of tetracyclic triterpenoids, including tirucallane and euphane. The biosynthesis pathways of limonoids

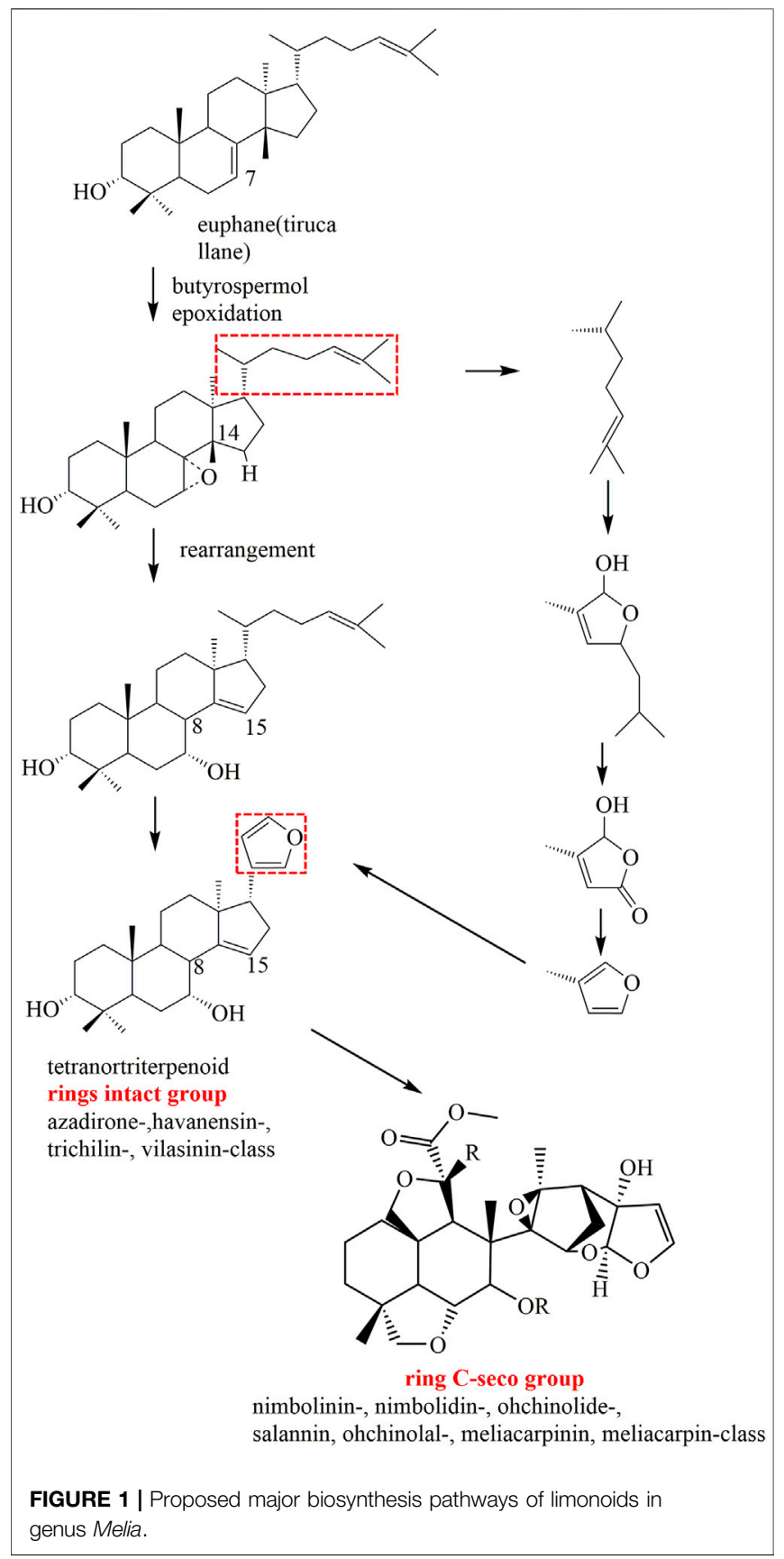


TABLE 1 | Classifications and sources of limonoids isolated from genus Melia.

\begin{tabular}{|c|c|c|c|c|}
\hline No & Compounds & Part of plant & Sources & Reference \\
\hline & Trichilin class & & & \\
\hline 1 & Azedarachin A & Stem barks & M. toosendan & Zhou et al. (1996) \\
\hline 2 & 12-O-Acetylazedarachin A & Root barks & M. toosendan & Nakatani (1999) \\
\hline 3 & 12-O-Acetylazedarachin B & Stem barks & M. toosendan & Zhou et al. (1996) \\
\hline 4 & Azedarachin C & Root barks & M. azedarach & $\begin{array}{l}\text { D'Ambrosio and Guerriero } \\
(2002)\end{array}$ \\
\hline 5 & Azedarachin B & Root barks & M. toosendan & Nakatani (1999) \\
\hline 6 & Sendanin & $\begin{array}{l}\text { Stem and root } \\
\text { barks }\end{array}$ & M. toosendan & Nakatani (1999) \\
\hline 7 & 12-Hydroxyamoorastatin & Root barks & M. toosendan & Nakatani (1999) \\
\hline 8 & Toosendanin & Stem barks & M. toosendan & Zhang et al. (2010c) \\
\hline 9 & 12-O-Deacetyltrichilin H & Fruits & M. azedarach & Zhou et al. (2005) \\
\hline 10 & 12-Acetyltrichilin B & Root barks & M. azedarach & Nakatani et al. (1994) \\
\hline 11 & 7,12-Diacetyltrichilin B & Root barks & M. azedarach & Nakatani et al. (1994) \\
\hline 12 & Trichilin H & Stem barks & M. toosendan & Zhou et al. (1996) \\
\hline 13 & Trichilin B & Root barks & M. toosendan & Nakatani (1999) \\
\hline 14 & Trichilin D & Root barks & M. azedarach & Nakatani et al. (1994) \\
\hline 15 & Meliatoxin A2 & Root barks & M. azedarach & Nakatani et al. (1994) \\
\hline 16 & Trichilin K & Stem barks & M. toosendan & Zhou et al. (1996) \\
\hline 17 & Trichilin L & Stem barks & M. toosendan & Zhou et al. (1996) \\
\hline 18 & Trichilin I & Stem barks & M. toosendan & Zhou et al. (1996) \\
\hline 19 & Trichilin J & Stem barks & M. toosendan & Zhou et al. (1996) \\
\hline 20 & 12-Deacetyltrichilin I & Barks & M. azedarach & Takeya et al. (1996b) \\
\hline 21 & 1-Acetyltrichilin $\mathrm{H}$ & Barks & M. azedarach & Takeya et al. (1996b) \\
\hline 22 & 3-Deacetyltrichilin $\mathrm{H}$ & Barks & M. azedarach & Takeya et al. (1996b) \\
\hline 23 & 1-Acetyl-3-deacetyltrichilin $\mathrm{H}$ & Barks & M. azedarach & Takeya et al. (1996b) \\
\hline 24 & 1-Acetyl-2-deacetyltrichilin $\mathrm{H}$ & Barks & M. azedarach & Takeya et al. (1996b) \\
\hline 25 & 1,12-Diacetyltrichilin B & Barks & M. azedarach & Takeya et al. (1996b) \\
\hline 26 & Meliatoosenin C & Stem barks & M. toosendan & Zhang et al. (2010c) \\
\hline 27 & $\begin{array}{l}\text { 24-Norchola-20,22-diene-4-carboralde-hyde-14,15:21,23-diepoxy-1,3,7,12,19- } \\
\text { pentachydroxy-4,8-dimethyl-11-oxo-cyclic-4,19-hemiacetal } \\
{[\mathrm{C}(\mathrm{S}), 1 \alpha, 3 \alpha, 4 \beta, 5 \alpha, 7 \alpha, 12 \alpha, 13 \alpha, 14 \beta, 15 \beta, 17 \alpha]-(9 \mathrm{Cl})}\end{array}$ & Stem barks & M. toosendan & Zhang et al. (2010c) \\
\hline 28 & Meliatoosenin D & Stem barks & M. toosendan & Zhang et al. (2010c) \\
\hline 29 & 1-O-Acetyltrichilin $\mathrm{H}$ & Root barks & M. toosendan & Zhou et al. (1998) \\
\hline 30 & 12-Acetoxyamoorastatin & Barks & M. azedarach & Ahn et al. (1994) \\
\hline 31 & 7-Benzoyltoosendanin & Seeds & M. azedarach & Liu et al. (2011) \\
\hline 32 & 7-Cinnamoyltoosendanin & Seeds & M. azedarach & Liu et al. (2011) \\
\hline 33 & Meliarachin B & $\begin{array}{l}\text { Twigs and } \\
\text { leaves }\end{array}$ & M. azedarach & Su et al. (2011) \\
\hline 34 & Meliarachin C & $\begin{array}{l}\text { Twigs and } \\
\text { leaves }\end{array}$ & M. azedarach & Su et al. (2011) \\
\hline 35 & Meliatoxin B1 & Fruits & M. toosendan & Tada et al. (1999) \\
\hline 36 & 12a-Hydroxymeliatoxin B1 & Fruits & M. toosendan & Zhu et al. (2014) \\
\hline 37 & 12a-Acetoxylmeliatoxin B2 & Fruits & M. toosendan & Zhu et al. (2014) \\
\hline 38 & Meliatoosenin G & Fruits & M. toosendan & Zhang et al. (2012) \\
\hline 39 & Meliatoosenin $\mathrm{H}$ & Fruits & M. toosendan & Zhang et al. (2012) \\
\hline 40 & 29-[(2-Methylbutanoyl)oxy]-2 $\alpha$-hydroxyamoorastatone & Root barks & M. toosendan & Zhou et al. (2009) \\
\hline 41 & 1,3-epi-29-[(2-Methylpropanoyl)oxy]-2 $\alpha$-hydroxyamoorastatone & Root barks & M. toosendan & Zhou et al. (2009) \\
\hline 42 & Isotoosendanin & Fruits & M. toosendan & Xie et al. (2008) \\
\hline 43 & Meliarachin L & Fruits & M. toosendan & Yan et al. (2020) \\
\hline 44 & Neoazedarachin A & Root barks & M. toosendan & Zhou et al. (1998) \\
\hline 45 & Neoazedarachin B & Root barks & M. toosendan & Zhou et al. (1998) \\
\hline 46 & Neoazedarachin D & Root barks & M. toosendan & Zhou et al. (1998) \\
\hline 47 & $12 \alpha$-Hydroxyamoorastatone & Root barks & M. toosendan & Zhou et al. (1998) \\
\hline 48 & Amoorastatone & Fruits & M. toosendan & Wang et al. (2020a) \\
\hline 49 & 12-Dehydroneoazedarachin D & Fruits & M. azedarach & Akihisa et al. (2013) \\
\hline 50 & Meliatoxin B2 & Barks & M. azedarach & Huang et al. (1994) \\
\hline 51 & Meliarachin G & $\begin{array}{l}\text { Twigs and } \\
\text { leaves }\end{array}$ & M. azedarach & Su et al. (2011) \\
\hline 52 & Meliarachin $\mathrm{H}$ & $\begin{array}{l}\text { Twigs and } \\
\text { leaves }\end{array}$ & M. azedarach & Su et al. (2011) \\
\hline 53 & Meliarachin I & $\begin{array}{l}\text { Twigs and } \\
\text { leaves }\end{array}$ & M. azedarach & Su et al. (2011) \\
\hline
\end{tabular}


TABLE 1 | (Continued) Classifications and sources of limonoids isolated from genus Melia.

\begin{tabular}{|c|c|c|c|c|}
\hline No & Compounds & Part of plant & Sources & Reference \\
\hline 54 & Meliarachin J & $\begin{array}{l}\text { Twigs and } \\
\text { leaves }\end{array}$ & M. azedarach & Su et al. (2011) \\
\hline 55 & Meliarachin K & $\begin{array}{l}\text { Twigs and } \\
\text { leaves }\end{array}$ & M. azedarach & Su et al. (2011) \\
\hline 56 & $12 \alpha$-Hydroxymeliatoosenin I & Fruits & M. toosendan & Zhu et al. (2014) \\
\hline 57 & Meliatoosenin I & Fruits & M. toosendan & Zhang et al. (2012) \\
\hline 58 & Meliatoosenin J & Fruits & M. toosendan & Zhang et al. (2012) \\
\hline 59 & Mesendanin $\mathrm{H}$ & $\begin{array}{l}\text { Twigs and } \\
\text { leaves }\end{array}$ & M. toosendan & Dong et al. (2010) \\
\hline 60 & Meliarachin D & $\begin{array}{l}\text { Twigs and } \\
\text { leaves }\end{array}$ & M. azedarach & Su et al. (2011) \\
\hline 61 & Meliarachin E & $\begin{array}{l}\text { Twigs and } \\
\text { leaves }\end{array}$ & M. azedarach & Su et al. (2011) \\
\hline 62 & Meliazedalides B & Fruits & M. azedarach & Qiu et al. (2019) \\
\hline 63 & Toosendalactonins & Fruits & M. azedarach & Park et al. (2020) \\
\hline 64 & Meliatoosenin E & Fruits & M. toosendan & Zhang et al. (2012) \\
\hline 65 & Mesendanin G & $\begin{array}{l}\text { Twigs and } \\
\text { leaves }\end{array}$ & M. toosendan & Dong et al. (2010) \\
\hline 66 & Meliartenin & Fruits & M. azedarach & Carpinella et al. (2003) \\
\hline \multirow[t]{2}{*}{67} & Toosendanal & Fruits & M. toosendan & Tada et al. (1999) \\
\hline & Vilasinin class & & & \\
\hline 68 & Meliatoosenin $\mathrm{K}$ & Fruits & M. toosendan & Zhang et al. (2012) \\
\hline 69 & Trichilinin D & Root barks & M. toosendan & Nakatani (1999) \\
\hline 70 & Trichilinin E & Root barks & M. toosendan & Nakatani (1999) \\
\hline 71 & Toosendansin $\mathrm{H}$ & Fruits & M. toosendan & Li et al. (2020b) \\
\hline 72 & 1-O-cinnamoyltrichilinin & Fruits & M. toosendan & Nakatani et al. (2000) \\
\hline 73 & Trichilinin B & Root barks & M. toosendan & Nakatani (1999) \\
\hline 74 & Trichilinin C & Root barks & M. toosendan & Nakatani (1999) \\
\hline 75 & $\begin{array}{l}\text { 24, 25,26, 27-Tetranorapotirucalla-(apoeupha)- } 1 \alpha \text {-tigloyloxy-3 } \alpha, 7 \alpha \text {-dihydroxyl-12 } \alpha \text {-acetoxyl- } \\
\text { 14, 20, 22-trien-21, 23-epoxy-6,28-epoxy }\end{array}$ & Fruits & M. toosendan & Zhang et al. (2010d) \\
\hline 76 & Meliavolkin & Barks & M. volkensii & Zeng et al. (1995a) \\
\hline 77 & Meliavolkinin & Barks & M. volkensii & Rogers et al. (1998a) \\
\hline 78 & 1,3-Diacetylvilasinin & Barks & M. volkensii & Rogers et al. (1998a) \\
\hline 79 & 1-Acetyltrichilinin & Fruits & M. volkensii & Jaoko et al. (2020) \\
\hline 80 & 1-Tigloyltrichilinin & Fruits & M. volkensii & Jaoko et al. (2020) \\
\hline 81 & 11,15-Dioxotrichilinin & Fruits & M. toosendan & Zhu et al. (2014) \\
\hline \multirow[t]{2}{*}{82} & Toosendansin I & Fruits & M. toosendan & Li et al. (2020b) \\
\hline & Havanensin class & & & \\
\hline 83 & Mesendanin C & $\begin{array}{l}\text { Twigs and } \\
\text { leaves }\end{array}$ & M. toosendan & Dong et al. (2010) \\
\hline 84 & Mesendanin D & $\begin{array}{l}\text { Twigs and } \\
\text { leaves }\end{array}$ & M. toosendan & Dong et al. (2010) \\
\hline 85 & Sendanal B & Fruits & M. toosendan & Yan et al. (2020) \\
\hline 86 & $\begin{array}{l}\text { 24,25,26,27-Tetra-norapotirucalla-(apoeupha)- } 1 \alpha, 6 \alpha, 12 \alpha \text {-triacetoxyl-3 } \alpha, 7 \alpha \text {-dihydroxyl-28- } \\
\text { aldehyde-14,20,22-trien-21,23-epoxy }\end{array}$ & Fruits & M. toosendan & Zhang et al. (2013) \\
\hline 87 & 14,15-Deoxy-11-oxohavanensin 3,12-diacetate & Fruits & M. toosendan & Zhu et al. (2014) \\
\hline 88 & Mesendanin A & $\begin{array}{l}\text { Twigs and } \\
\text { leaves }\end{array}$ & M. toosendan & Dong et al. (2010) \\
\hline 89 & Mesendanin B & $\begin{array}{l}\text { Twigs and } \\
\text { leaves }\end{array}$ & M. toosendan & Dong et al. (2010) \\
\hline 90 & Mesendanin J & $\begin{array}{l}\text { Twigs and } \\
\text { leaves }\end{array}$ & M. toosendan & Dong et al. (2010) \\
\hline 91 & Toosendone & Fruits & M. toosendan & Zhang et al. (2007) \\
\hline 92 & Butenolide & Root barks & M. toosendan & Nakatani (1999) \\
\hline 93 & Meliarachin A & $\begin{array}{l}\text { Twigs and } \\
\text { leaves }\end{array}$ & M. azedarach & Su et al. (2011) \\
\hline 94 & Melianin C & Barks & M. volkensii & Rogers et al. (1998a) \\
\hline 95 & Meliatoosenin F & Fruits & M. toosendan & Zhang et al. (2012) \\
\hline 96 & Mesendanin I & $\begin{array}{l}\text { Twigs and } \\
\text { leaves }\end{array}$ & M. toosendan & Dong et al. (2010) \\
\hline
\end{tabular}


TABLE 1 | (Continued) Classifications and sources of limonoids isolated from genus Melia.

\begin{tabular}{|c|c|c|c|c|}
\hline No & Compounds & Part of plant & Sources & Reference \\
\hline & Azadirone class & & & \\
\hline 97 & Meliatoosenin A & Stem barks & M. toosendan & Zhang et al. (2010c) \\
\hline 98 & Azadirone & Root barks & M. toosendan & Nakatani (1999) \\
\hline \multirow[t]{2}{*}{99} & Acetyltrichilenone & Root barks & M. toosendan & Nakatani (1999) \\
\hline & Nimbolinin class & & & \\
\hline 100 & 12-O-Methylvolkensin & Fruits & M. toosendan & Tada et al. (1999) \\
\hline 101 & 1-Deacetylnimbolinin A & Root barks & M. toosendan & Nakatani et al. (1999) \\
\hline 102 & Nimbolinin A & Fruits & M. toosendan & Su et al. (2013) \\
\hline 103 & Nimbolinin C & Fruits & M. toosendan & Nakatani et al. (2000) \\
\hline 104 & Nimbolinin D & Fruits & M. toosendan & Nakatani et al. (2000) \\
\hline 105 & Nimbolinin B & Fruits & M. toosendan & Su et al. (2013) \\
\hline 106 & 1-Deacetylnimbolinin B & Fruits & M. toosendan & Su et al. (2013) \\
\hline 107 & 12-Ethoxynimbolinins A & Fruits & M. toosendan & Zhang et al. (2007) \\
\hline 108 & 12-Ethoxynimbolinins B & Fruits & M. toosendan & Zhang et al. (2007) \\
\hline 109 & 12-Ethoxynimbolinins C & Fruits & M. toosendan & Zhang et al. (2007) \\
\hline 110 & 12-Ethoxynimbolinins D & Fruits & M. toosendan & Zhang et al. (2007) \\
\hline 111 & 12-Ethoxynimbolinins $\mathrm{H}$ & Barks & M. toosendan & Zhang et al. (2018) \\
\hline 112 & Nimbolin B & Root barks & M. volkensii & Zeng et al. (1995b) \\
\hline 113 & 1-Decinnamoyl-1-(2'-methylacryloyl) nimbolinin C & Fruits & M. toosendan & Zhu et al. (2014) \\
\hline 114 & 1-Decinnamoylnimbolinin C & Fruits & M. toosendan & Zhu et al. (2014) \\
\hline 115 & 12-O-Methyl-1-O-deacetylnimbolinin B & Fruits & M. toosendan & Hu et al. (2011) \\
\hline 116 & 12-O-Methyl-1-O-tigloyl-1-O-deacetylnimbolinin B & Fruits & M. toosendan & Hu et al. (2011) \\
\hline 117 & 12-O-Ethylnimbolinin B & Fruits & M. toosendan & Hu et al. (2011) \\
\hline 118 & $1 \alpha, 7 \alpha$-Dihydroxyl- $3 \alpha$-acetoxyl- $12 \alpha$-ethoxylnimbolinin & Fruits & M. toosendan & Zhang et al. (2016) \\
\hline 119 & $1 \alpha$-Tigloyloxy- $3 \alpha$-acetoxyl- $7 \alpha$-hydroxyl- $12 \beta$-ethoxylnimbolinin & Fruits & M. toosendan & Zhang et al. (2016) \\
\hline 120 & $1 \alpha, 3 \alpha$-Dihydroxyl- $7 \alpha$-tigloyloxy- $12 \alpha$-ethoxylnimbolinin & Fruits & M. toosendan & Zhang et al. (2016) \\
\hline 121 & 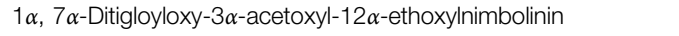 & Fruits & M. toosendan & Zhang et al. (2016) \\
\hline 122 & 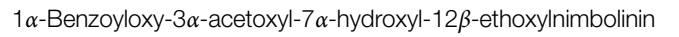 & Fruits & M. toosendan & Zhang et al. (2013) \\
\hline 123 & 12 $\alpha$-1-O-Tigloyl-1-O-deacetyl-nimbolinin B & Fruits & M. toosendan & Su et al. (2013) \\
\hline 124 & 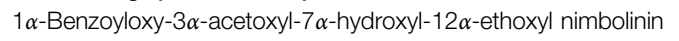 & Fruits & M. toosendan & Zhang et al. (2010b) \\
\hline 125 & 1-O-Benzoyl-3-O-deactylnim-bolinin C & Fruits & M. azedarach & Park et al. (2020) \\
\hline 126 & 1-Benzoylnimbolinin C & Seeds & M. azedarach & Liu et al. (2011) \\
\hline 127 & Meliatoosenin L & Fruits & M. toosendan & Zhang et al. (2012) \\
\hline 128 & Meliatoosenin N & Fruits & M. toosendan & Zhang et al. (2012) \\
\hline 129 & Toosendansins B & Fruits & M. toosendan & Chen et al. (2014) \\
\hline 130 & 3-Deacetyl-12-O-methylvolkensin & Fruits & M. toosendan & Zhu et al. (2014) \\
\hline 131 & Meliatoosenin T & Fruits & M. toosendan & Yan et al. (2020) \\
\hline 132 & Meliatoosenin U & Fruits & M. toosendan & Yan et al. (2020) \\
\hline \multirow[t]{2}{*}{133} & Meliazedalides A & Fruits & M. azedarach & Qiu et al. (2019) \\
\hline & Ohchinolide class & & & \\
\hline 134 & Ohchinolide A & Fruits & M. azedarach & Ochi et al. (1979) \\
\hline 135 & Ohchinolide B & Root barks & M. toosendan & Zhou et al. (1997) \\
\hline 136 & Ohchinolide C & Barks & M. toosendan & Zhou et al. (1997) \\
\hline 137 & 1-O-Deacetyl-1-O-tigloylohchinolide B & Fruits & M. azedarach & Zhou et al. (2004) \\
\hline 138 & 1-O-Deacetyl-1-O-benzoylohchinolide B & Fruits & M. azedarach & Zhou et al. (2004) \\
\hline 139 & 1-O-Deacetyl-1-O-tigloylohchinolide A & Fruits & M. azedarach & Zhou et al. (2004) \\
\hline 140 & 1-O-Deacetylohchinolide B & Fruits & M. azedarach & Zhou et al. (2004) \\
\hline 141 & 1-O-Deacetylohchinolide A & Fruits & M. azedarach & Zhou et al. (2004) \\
\hline \multirow[t]{2}{*}{142} & Azecin 2 & Roots & M. azedarach & Tan and Luo (2011) \\
\hline & Nimbolidin class & & & \\
\hline 143 & Nimbolidin F & Barks & M. toosendan & Zhou et al. (1997) \\
\hline 144 & Nimbolidin D & Barks & M. toosendan & Zhou et al. (1997) \\
\hline 145 & Nimbolidin C & Root barks & M. toosendan & Nakatani et al. (1996) \\
\hline 146 & Nimbolidin E & Root barks & M. toosendan & Nakatani et al. (1996) \\
\hline 147 & Nimbolidin B & Root barks & M. toosendan & Nakatani et al. (1996) \\
\hline 148 & 15-O-Deacetyl-15-O-methylnimbolidin A & Fruits & M. azedarach & Zhou et al. (2005) \\
\hline 149 & 15-O-Deacetyl-15-O-methylnimbolidin B & Fruits & M. azedarach & Zhou et al. (2005) \\
\hline 150 & 15-O-DeacetyInimbolidin B & Fruits & M. azedarach & Zhou et al. (2005) \\
\hline
\end{tabular}

(Continued on following page) 
TABLE 1 | (Continued) Classifications and sources of limonoids isolated from genus Melia.

\begin{tabular}{|c|c|c|c|c|}
\hline No & Compounds & Part of plant & Sources & Reference \\
\hline & Salannin class & & & \\
\hline 151 & 1-O-Cinnamoyl-1-O-debenzoylohchinal & Fruits & M. toosendan & Hu et al. (2011) \\
\hline 152 & 1-O-Tigloyl-1-O-debenzoylohchinal & Fruits & M. toosendan & Hu et al. (2011) \\
\hline 153 & Salannin & Root barks & M. toosendan & Nakatani et al. (1996) \\
\hline 154 & 3-O-Deacetylsalanni & Fruits & M. azedarach & Akihisa et al. (2013) \\
\hline 155 & Ohchinal & Fruits & M. toosendan & Wang et al. (2020a) \\
\hline 156 & Ohchinin & Leaves & M. azedarach & Pan et al. (2014b) \\
\hline 157 & 1-O-Decinnamoyl-1-O-benzoylohchinin & Fruits & M. azedarach & Akihisa et al. (2013) \\
\hline 158 & 3-Deacetyl-4'-demethylsalannin & Fruits & M. azedarach & Pan et al. (2014a) \\
\hline 159 & 3-Deacetyl-3-tigloylsalannin & Fruits & M. azedarach & Akihisa et al. (2017) \\
\hline 160 & $2^{\prime}, 3^{\prime}$-Dihydrosalannin & Fruits & M. volkensii & Jaoko et al. (2020) \\
\hline 161 & 1-Detigloyl-1-isobutylsalannin & Fruits & M. volkensii & Jaoko et al. (2020) \\
\hline 162 & Ohchinin-acetate & Fruits & M. volkensii & Jaoko et al. (2020) \\
\hline 163 & Ohchininolide & Fruits & M. azedarach & Akihisa et al. (2013) \\
\hline 164 & 1-O-Decinnamoyl-1-O-benzoylohchininolide & Fruits & M. azedarach & Akihisa et al. (2013) \\
\hline 165 & 23-Hydroxyohchininolide & Leaves & M. azedarach & Pan et al. (2014b) \\
\hline 166 & 23-Methoxyohchininolide A & Fruits & M. azedarach & Akihisa et al. (2013) \\
\hline 167 & 1-O-Decinnamoyl-1-O-benzoyl-23-hydroxyohchininolide & Fruits & M. azedarach & Akihisa et al. (2013) \\
\hline 168 & 3-Deacetyl-28-oxosalannin & Leaves & M. azedarach & Pan et al. (2014b) \\
\hline 169 & 3-Deacetyl-4'-demethyl-28-oxosalannin & Leaves & M. azedarach & Pan et al. (2014b) \\
\hline 170 & 1-O-Decinnamoyl-1-O-benzoyl-28-oxoohchinin & Fruits & M. azedarach & Akihisa et al. (2013) \\
\hline 171 & 3-Deacetyl-28-oxosalannolactone & Leaves & M. azedarach & Pan et al. (2014b) \\
\hline 172 & 3-Deacetyl-28-oxoisosalanninolide & Leaves & M. azedarach & Pan et al. (2014b) \\
\hline 173 & 3-Deacetyl-17-defurano-17,28-dioxosalannin & Leaves & M. azedarach & Pan et al. (2014b) \\
\hline 174 & 21-Hydroxyisoohchininolide & Leaves & M. azedarach & Akihisa et al. (2013) \\
\hline 175 & 17-Defurano-17-oxoohchinin & Fruits & M. azedarach & Akihisa et al. (2013) \\
\hline 176 & Meliatoosenin P & Fruits & M. toosendan & Zhang et al. (2012) \\
\hline \multirow[t]{2}{*}{177} & Meliatoosenin Q & Fruits & M. toosendan & Zhang et al. (2012) \\
\hline & Ohchinolal class & & & \\
\hline 178 & 3-O-Acetylohchinolal & Barks & M. toosendan & Zhou et al. (1997) \\
\hline 179 & 1-Detigloylohchinolal & Fruits & M. azedarach & Pan et al. (2014a) \\
\hline 180 & 1-Benzoyl-1-detigloylohchinolal & Fruits & M. azedarach & Akihisa et al. (2017) \\
\hline 181 & 1-Cinnamoyl-1-detigloylohchinolal & Fruits & M. azedarach & Akihisa et al. (2017) \\
\hline 182 & Ohchinolal & Root barks & M. toosendan & Zhou et al. (1997) \\
\hline 183 & Mesendanin E & Fruits & M. azedarach & $\begin{array}{l}\text { (Dong et al., 2010; Pan et al., } \\
\text { 2014a) }\end{array}$ \\
\hline 184 & Mesendanin F & $\begin{array}{l}\text { Twigs and } \\
\text { leaves }\end{array}$ & M. toosendan & Dong et al. (2010) \\
\hline 185 & Toosendansin G & Fruits & M. toosendan & Li et al. (2020b) \\
\hline \multirow[t]{2}{*}{186} & Meliatoosenin R & Fruits & M. toosendan & Zhang et al. (2012) \\
\hline & Meliacarpinin class & & & \\
\hline 187 & Toosendane A & Barks & M. toosendan & Hu et al. (2018) \\
\hline 188 & Toosendane B & Barks & M. toosendan & Hu et al. (2018) \\
\hline 189 & Toosendane C & Barks & M. toosendan & Hu et al. (2018) \\
\hline 190 & 3,20-Diacetyl-11-methoxymeliacarpinin & Barks & M. toosendan & Hu et al. (2018) \\
\hline 191 & 3,20-Diacetyl-1-tigloyl-11-methoxymeliacarpinin & Barks & M. toosendan & Hu et al. (2018) \\
\hline 192 & Meliacarpinin A & Root barks & M. toosendan & Nakatani (1999) \\
\hline 193 & Meliacarpinin C & Root barks & M. toosendan & Nakatani (1999) \\
\hline 194 & Meliacarpinin D & Root barks & M. toosendan & Nakatani (1999) \\
\hline 195 & Meliacarpinin E & Root barks & M. azedarach & Huang et al. (1996) \\
\hline 196 & 1-Deoxy-3-tigloyl-11-methoxymeliacarpinin & Barks & M. azedarach & Huang et al. (1994) \\
\hline 197 & 3 $\alpha$-(2-Methylbutyryl)-1,20-diacetyl-11-methoxymeliacarpinin & $\begin{array}{l}\text { Twigs and } \\
\text { leaves }\end{array}$ & M. azedarach & Zhang et al. (2014) \\
\hline 198 & 3-Tigloyl-1,20-diacetyl-11-methoxymeliacarpinin & $\begin{array}{l}\text { Twigs and } \\
\text { leaves }\end{array}$ & M. azedarach & Zhang et al. (2014) \\
\hline 199 & 1-Methacrylyl-3-acetyl-11-methoxymeliacarpinin & Roots & M. azedarach & Nakatani (1999) \\
\hline 200 & 1-(2-Methylpropanoyl)-3-acetyl-11-methoxymeliacarpinin & Roots & M. azedarach & Nakatani (1999) \\
\hline 201 & 1-Cinnamoyl-3-hydroxy- 11-methoxymeliacarpinin & Barks & M. azedarach & Takeya et al. (1996a) \\
\hline 202 & 1-Deoxy-3-methacrylyl-11-methoxymeliacarpinin & Barks & M. azedarach & Takeya et al. (1996a) \\
\hline
\end{tabular}

(Continued on following page) 
TABLE 1 | (Continued) Classifications and sources of limonoids isolated from genus Melia

\begin{tabular}{|c|c|c|c|c|}
\hline No & Compounds & Part of plant & Sources & Reference \\
\hline & \multicolumn{4}{|l|}{ Meliacarpin class } \\
\hline 203 & 1,3-Dicinnamoyl-11-hydroxymeliacarpin & Leaves & M. azedarach & Bohnenstengel et al. (1999) \\
\hline 204 & 1-Cinnamoyl-3-methacrylyl-11-hydroxymeliacarpin & Leaves & M. azedarach & Bohnenstengel et al. (1999) \\
\hline 205 & 1-Cinnamoyl-3-acetyl-11-hydroxymeliacarpin & Leaves & M. azedarach & Bohnenstengel et al. (1999) \\
\hline 206 & 1-Cinnamoyl-3-feruloyl-11-hydroxymeliacarpin & Leaves & M. azedarach & Bohnenstengel et al. (1999) \\
\hline 207 & Azadirachtin & Leaves & M. azedarach & Bohnenstengel et al. (1999) \\
\hline \multirow[t]{2}{*}{208} & 1-Cinnamoyl-3,11-dihydroxymeliacarpin & Leaves & M. azedarach & Barquero et al. (2006) \\
\hline & \multicolumn{4}{|l|}{ Others } \\
\hline 209 & Meliatoosenin S & Fruits & M. toosendan & Zhang et al. (2012) \\
\hline 210 & Spirosendan & Root barks & M. toosendan & Nakatani et al. (1999) \\
\hline 211 & Volkensinin & Barks & M. volkensii & Rogers et al. (1998b) \\
\hline 212 & Azecin 1 & Roots & M. azedarach & Tan and Luo (2011) \\
\hline 213 & Azecin 3 & Roots & M. azedarach & Tan and Luo (2011) \\
\hline 214 & Azecin 4 & Roots & M. azedarach & Tan and Luo (2011) \\
\hline
\end{tabular}

are shown in Figure1. Firstly, the $\Delta^{7}$-double bond is oxidized to 7 epoxy, which was subsequently opened to cause a Wagner-Meerwein shift of Me-14 to C-8, and finally leads to the formation of $\mathrm{OH}-7$ and the introduction of a double bond at C-14/15. On this basis, four carbons are lost from the rear side chain to form a $17-\beta$-furan ring, and the last step is finished after the formation of the 4,4,8-trimethylsteroid skeleton, which was regarded as the basic limonoid skeleton (Tan and Luo, 2011). The limonoids in genus Melia are mainly classified into two classes, including the ring-intact limonoids and the ring-C-seco limonoids, and the detailed chemical information will be discussed in this review (Table 1).

\section{Trichilin Class (1-67)}

The basic skeleton of the trichilin class limonoids contained the C-19/ 29 bridged acetal and the 14,15-epoxide moieties or C15 carbonyl. Toosendanin, as a characteristic compound in trichilin class, has been confirmed to be a potential bioactive component in the field of antitumor, insecticide, and anti-botulism. It should be noted that toosendanin can only be isolated from two plant species, $M$. toosendan and M. azedarach (Shi and Li, 2007). The first isolation and identification of toosendanin can be traced back to 1975. In 1980, Chinese researchers corrected its chemical structure due to the occurrence of two tautomers found by paper chromatography and silica gel plate method (Su and Liang, 1980). In 1984, iso-toosendanin, the isomer of toosendanin, was also isolated from these two plants. In 1998, Zhou et al. isolated four new trichilin class limonoids from the root barks of $M$. toosendan, of which neoazedarachin $\mathrm{D}$ was found to be the first natural 29-endo-derivative in C (19)/C (29) bridged acetal limonoids (Zhou et al., 1998). Apart from C-19/29 bridged acetal, toosendanal with C (1)/C (29) bridged acetal was also discovered in $M$. toosendan (Tada et al., 1999) (Figure 2).

\section{Vilasinin Class (68-82)}

$6 \alpha, 28$-ether bridge was supposed to be a typical skeleton of vilasinin class limonoids. Trichilinin B, C, D, and E, four new limonoids with $6 \alpha, 28$-ether bridge, were isolated and identified from the root barks of $M$. toosendan. It was found that the unique C-12 oxygen function in trichilinin B, C, and E seemed to be the biosynthetic precursors of ring-C-cleaved limonoids (Nakatani, 1999). Using activity-guided separation, meliavolkin was isolated from $M$. volkensii Gürke., and its structure was elucidated by $\mathrm{MS},{ }^{1} \mathrm{H}$ and ${ }^{13} \mathrm{C}$ NMR, COSY, NOESY, HETCOR, and COLOC spectra (Zeng et al., 1995a) (Figure 3A).

\section{Havanensin Class (83-96)}

The havanensin class limonoids were characteristic of C-1, C-3, and C-7 oxygen substituents, and C-28 will be oxidized, which varies from methyl to carboxyl. In 1998, melianin C was isolated from M. volkensii Gürke., which was confirmed to have a consistent structure with the semisynthetic compound obtained by Jones oxidation of melianin A, and it was also the first report that melianin $\mathrm{C}$ appeared naturally (Rogers LL. et al., 1998). Sendanal was associated closely with a precursor of the 14,15-epoxy-12-hydroxymoiety, which could produce the ring-seco limonoids through a Grob fragmentation followed by the formation of an ether ring between the C-7 and C-15 hydroxyl groups via an $\mathrm{S}_{\mathrm{N}} 1$ mechanism (Tan and Luo, 2011) (Figure 3B).

\section{Azadirone Class (97-99)}

The 3-oxo- $\Delta^{1,2}$ and C-7 oxygenation was considered as a vital feature of azadirone-type limonoids. The first isolation of azadirone can be traced back to 1998, and it was firstly isolated from the root barks of $M$. toosendan, together with acetyltrichilenone (Nakatani, 1999) (Figure 3C).

\section{Ring-Seco Limonoids (100-208)}

The ring-C-seco limonoids have the most typical chemical structure of all ring-seco limonoids. According to different structural characteristics, the ring $\mathrm{C}$-seco limonoids can be classified into nimbolinin class, ohchinolide class, nimbolidin class, salannin class, ohchinolal class, meliacarpinin class, and meliacarpin class (Figures 4-6).

\section{SYNTHESIS OF LIMONOIDS}

Due to the remarkable pharmacological activities and the unique structural features, many endeavors have been devoted to the synthesis of limonoids found in the genus Melia. Inspired by the anti-botulinum effect and structural diversity of toosendanin, researchers have conducted a synthesis or structural modification of this chemical 
structure. Excitedly, a similar framework can be found in all mammalian steroids and hormones. Although total synthesis seems like an ideal synthesis approach, the complexity of structure and uncertainty of total synthesis make researchers choose functionoriented synthesis (FOS) as an alternative. FOS aims to emulate a bioactive lead structure or possibly substitute for it with simpler scaffolds designed to contain the active chemical structure sites of target compounds (Wender, 2013). Considering that there were no previous reports on bioactive structural features, Nakai et al. cleaved toosendanin into $\mathrm{AB}$ and $\mathrm{CD}$ rings, and the biological activity of $\mathrm{CD}$ rings was probed by mouse lethality assay, which was deemed to be a "gold standard" in the validation of anti-botulinum activity. Using mesityl oxide and acetylacetone as synthetic substrates, a 4-acetoxy CD fragment analogue of toosendanin was synthesized in 14 steps. Unluckily, no significant anti-botulinum effect was found in the obtained 4-acetoxy CD fragment. Nevertheless, this synthetic method can provide certain inspiration for synthesizing the $\mathrm{CD}$ ring analogues (Nakai et al., 2009). Later, in 2010, Nakai et al. focused on $\mathrm{AB}$ ring synthesis, which contained a unique bridged hemiacetal, and the anti-botulinum effect was tested in a rat spinal cord cellular assay. The $\mathrm{AB}$ ring and epi- $\mathrm{AB}$ ring were successfully synthesized with a yield rate of 5.8 and $10 \%$ after 23 steps and 19 steps, respectively. Similar to the previously synthesized $C D$ ring, the $A B$ ring did not exhibit anti-botulism activity. All of these results indicated that the complete structure of the $\mathrm{ABCD}$ ring is indispensable in the treatment of botulism (Nakai et al., 2010). Apart from exploring the influence of ring structure on the bioactivity of toosendanin, the role of substituents at different positions was investigated as well. By modifying the C-28 position of toosendanin, 12 28-acyloxy derivatives were semi-synthesized, and the insecticidal activity against Mythimna separata Walker was evaluated. The outcomes revealed that the butanoyloxy and phenyl acryloyl oxymoiety at the 28-position plays a critical role in insecticidal activity (Xu and Zhang, 2011) (Figure8). Except for the organic synthesis mentioned above, the biosynthesis of toosendanin also aroused great attention. Since the cyclization of 2,3-oxidosqualene by oxidosqualene cyclase (OSC) is the first stage of triterpenoid biosynthesis to produce diverse triterpene frameworks, Lian et al. found potential OSC genes in $M$. toosendan by utilizing the triterpenoid profile, transcriptome data, and phylogenetic analysis. The following functional analysis discovered that MtOSC1 was a crucial enzyme in the formation of tirucalla-7,24-dien-3 $\beta$-ol, which is a precursor for the biosynthesis of toosendanin (Lian et al., 2020). This study revealed that the practicable biosynthesis route of toosendanin may promote its application both in agricultural and medicinal use. Furthermore, salannin and 3-deacetylsalannin can be transformed into 3-deacetoxy-1-de[(E)-2-methylbut-2-enoloxy] salannin-1-en-3-one by Nocardia sp., and the transformed product was validated as a candidate bioactive compound with an $\alpha, \beta$ unsaturated ketone moiety in ring $\mathrm{A}$ (Madyastha and Venkatakrishnan, 2000).

\section{BIOLOGICAL ACTIVITIES OF LIMONOIDS}

\section{Anti-tumor Effects}

Accumulating studies have found that limonoids possessed broad-spectrum anti-tumor activities against multiple tumors, such as gastric tumor (Shao et al., 2020), lung tumor (Luo et al., 2018), colorectal tumor (Wang et al., 2015), glioblastoma (Cao et al., 2016), leukemia (Ju et al., 2012), ovarian tumor (Li et al., 2018b), hepatocellular carcinoma (He et al., 2010), breast tumor (Wang et al., 2018), Ewing's sarcoma (Gao et al., 2019), neuroma (Tang et al., 2004), lymphoma (Zhang B. et al., 2005), and pancreatic tumor (Pei et al., 2017), which indicated that limonoids could be candidate anticancer drugs. Toosendanin (TSN), as a quality control marker in $M$. toosendan and $M$. azedarach, has been systematically investigated for its anti-tumor effects. Thus, this review primarily focused on summarizing the anti-tumor activity of TSN and its underlying mechanisms, including the inhibition of tumor cell proliferation, induction of apoptosis, suppression of migration, and invasion. Besides these, we also comprehensively reviewed the anti-tumor bioactivities of other limonoids in genus Melia plants.

\section{Effect of Toosendanin on Tumor Cell Proliferation and Cell Cycle Arrest}

Tumor cell proliferation is the basis of tumor growth and metastasis. Inhibition of tumor cell proliferation has been considered as one of the pivotal anti-tumor therapies (Whitfield et al., 2006). It was found that TSN could inhibit the proliferation of $\mathrm{MKN}-45$ gastric cancer cells in a timedependent and dose-dependent manner, and the $\mathrm{IC}_{50}$ value was $81.06 \mathrm{nM}$ for $48 \mathrm{~h}$ (Shao et al., 2020). In addition, some other experiments showed that TSN was able to restrain the proliferation of various cancer cell lines, including SGC-7901 cells (Wang et al., 2017), MGC-803 cells, and HGC-27 cells with $\mathrm{IC}_{50}$ values of $0.11 \mu \mathrm{M}(72 \mathrm{~h}), 20.30 \mathrm{nM}(72 \mathrm{~h})$, and $0.56 \mu \mathrm{M}(48 \mathrm{~h})$, respectively. Using the MTT method, Liu et al. reported that the proliferation of lung cancer A 549 cells could be inhibited by TSN with an $\mathrm{IC}_{50}$ value of $40.206 \mu \mathrm{M}$ for $48 \mathrm{~h}$. Meanwhile, the same inhibitory effect was found in H1975 lung cancer cells. When treating colorectal cancer SW480 cells with TSN, it exhibited antiproliferation effects with an $\mathrm{IC}_{50}$ value of $0.1059 \mu \mathrm{M}(48 \mathrm{~h})$ (Wang et al., 2015). In order to further explore the anti-tumor effect of TSN in colorectal cancer, a nude mouse xenograft model was established, which subcutaneously inoculated HCT116 cells into nude mice. The outcomes indicated that TSN significantly reduced the tumor volume and weight of the HCT116 xenografts (Wang et al., 2020b). Apart from cancer mentioned above, TSN was found to possess anti-proliferation effects on some other types of tumor, such as glioblastoma, leukemia, ovarian cancer, hepatocellular carcinoma, etc., with $\mathrm{IC}_{50}$ values ranging from 5.4 to $900 \mathrm{nM}$ (Zhang B. et al., 2005; He et al., 2010; Cao et al., 2016; Gao et al., 2019).

The proliferation of tumor cells needs to go through four different stages: pre-DNA synthesis (G1), DNA synthesis (S), late DNA synthesis (G2), and mitosis (M). Since the aberrant activity of various cyclins can lead to the uncontrolled proliferation of tumor cells, treating aberrant cyclins was thus considered as an attractive target for tumor therapy (Otto and Sicinski, 2017). Shao et al. found that TSN-treated MKN-45 human gastric cancer cells markedly arrested at the G1 phase, which was regulated by the overexpression of mir-23a-3p (Shao et al., 2020). In another study, researchers showed that treatment with TSN at 
concentrations of 2 and $5 \mu \mathrm{M}$ can cause G1/S arrest in AGS and HGC-27 gastric cancer cells. For a further evaluation of cell cycle arrest, the expression of G1 checkpoint-associated proteins, including cyclin D1 and p21, was assessed. It was observed that TSN treatment could decrease the expression of cyclin D1, while it could increase the expression of p21 (Zhou et al., 2018). Furthermore, in both 5-FU-sensitive and 5-FU-resistant colorectal cancer cells, G1 phase arrest could be induced by TSN. The results also found that, apart from decreased cyclin D1 and increased p21, the expression of p53, a G1-phase checkpointassociated protein, increased as well (Wang et al., 2020b). In addition, cell cycle arrest also occurred in other tumor cells, such as glioblastoma (Wang Q. et al., 2020) and leukemia (Ju et al., 2013).

\section{Effect of Toosendanin on Tumor Cell Apoptosis}

Concerning the anti-tumor effects of TSN, much work has focused on cell apoptosis. Inducing tumor cell apoptosis is now generally considered as the most important mechanism of anti-tumor drugs. Apoptosis, also known as programmed cell death, is a kind of cell-autonomous and orderly death mode, which is activated, expressed, and regulated by specific genes in cells (Li-Weber, 2013). TSN was recently regarded as a potential candidate that killed tumor cells through the induction of apoptosis in various cancer cells, including gastric cancer (Wang et al., 2017; Zhou et al., 2018; Shao et al., 2020), lung cancer (Wang et al., 2017), colorectal cancer (Wang et al., 2015; Wang et al., 2020b), glioblastoma (Cao et al., 2016; Wang Q. et al., 2020), leukemia (Ju et al., 2012; Ju et al., 2013), ovarian cancer (Li et al., 2018a; Li et al., 2019), hepatocellular carcinoma (He et al., 2010; Liu et al., 2016), breast cancer (Wang et al., 2018), Ewing's sarcoma (Gao et al., 2019), neuroma (Tang et al., 2004), and lymphoma (Zhang B. et al., 2005). Herein our study summed up the detailed mechanisms of apoptosis induced by TSN (Figure 9).

\section{Targeting the Intrinsic Pathway}

The intrinsic pathway is also known as cell mitochondrial apoptosis. When cells are exposed to various stimulating factors, such as hypoxia, activation of the oncogene, DNA damage, and cytotrophic factor deficiency, the steady state of mitochondrial membrane potential will be destroyed, and the permeability can increase. Subsequently, the pro-apoptotic factors in the mitochondrial membrane are released to the cytoplasm, which later activates the apoptosis pathway of the mitochondria and causes cell death (Estaquier et al., 2012). Cytochrome c (Cyt C), apoptosis-inducing factor, cysteinyl aspartate-specific proteinase (caspase) activator, and apoptotic protease-activating factor-1 (Apaf-1) are supposed to be pivotal pro-apoptotic factors. The apoptosome complex is formed by the combination of released Cyt $C$ with Apaf- 1 and caspase-9, which activates caspase-3 and eventually induces apoptosis. Importantly, regulating the B-cell lymphoma-2 (Bcl-2) protein family has been considered as an essential route to play a role in cell mitochondrial apoptosis signal pathway, the mechanism of which is to control the permeability of the mitochondrial membrane to regulate the release of Cyt C (Siddiqui et al., 2015).
Collectively, TSN-induced apoptosis of tumor cells is related to the activation of the intrinsic pathway. On the one hand, the capacity of cells to undergo mitochondrial apoptosis is governed by pro- and anti-apoptotic members of the Bcl-2 protein family. According to the difference of its functional domain, it can be divided into anti-apoptotic Bcl-2 subfamily (e.g., Bcl-2, Bcl-xL, and Mcl-1), pro-apoptotic Bax subfamily (e.g., Bax and Bak), and BH3-only pro-apoptotic family (e.g., Bid, Bim, Bik, and Noxa) (Campbell and Tait, 2018). On the other hand, the caspase family is known as the most well-studied apoptotic executive protein, which has the characteristics of post-aspartic protein hydrolysis. Based on their different roles in apoptosis, it can be classified into two types: the initiator (apical) caspases (e.g., caspase-2, -8, -9, and -10$)$ and effector (executioner) caspases (e.g., caspase-3, -6, and -7) (Ola et al., 2011). The caspase family implements its proapoptotic effect mainly through the combination of apoptosis signal and death receptor to induce the activation process of initiator and effector caspase protein and the subsequent inactivation process of apoptosis-inhibitory protein and cause nucleic acid and cell structure cleavage and so on (Fiandalo and Kyprianou, 2012). When administrated with TSN, several typical characteristics of apoptosis occurred, including nuclei condensation, DNA fragmentation, reduction of mitochondrial membrane potential, and the upregulation of cytochrome $c$ in cytosol (Tang et al., 2004; Shao et al., 2020). Subsequently, caspase 9 and caspase 3 were activated (Tang et al., 2004; He et al., 2010; Ju et al., 2013; Zhou et al., 2018; Gao et al., 2019; Wang et al., 2020b; Shao et al., 2020), and TSN promoted poly-ADP-ribose polymerase (a target protein of caspase 3 ) fragmentation (Tang et al., 2004; Ju et al., 2013; Zhou et al., 2018; Wang et al., 2020b), eventually leading to apoptosis. Some other researches showed that TSN treatment significantly increased the pro-apoptotic protein expression of Bax (He et al., 2010; Ju et al., 2013; Cao et al., 2016; Liu et al., 2016; Zhou et al., 2018; Gao et al., 2019; Shao et al., 2020), Bak (Cao et al., 2016), Bim, and Noxa Apaf-1 (Shao et al., 2020) and decreased the anti-apoptotic protein expression of Bcl-2 (He et al., 2010; Ju et al., 2013; Cao et al., 2016; Liu et al., 2016; Wang et al., 2017; Zhou et al., 2018; Gao et al., 2019; Wang et al., 2020b; Shao et al., 2020), Bcl-xL (Zhou et al., 2018; Wang et al., 2020b), Mcl-1 (Zhou et al., 2018; Wang et al., 2020b), and XIAP (Zhou et al., 2018; Wang et al., 2020b), thus inducing apoptosis-associated caspase activation.

\section{Targeting the Extrinsic Pathway}

The death receptor (DR)-mediated apoptosis signaling pathway is a kind of a signal pathway that interacts with proteins mediated by transmembrane receptors. Death receptors belong to the tumor necrosis factor receptor (TNFR) superfamily, including Fas (also known as CD95 or Apo-1), TNFR-1, TNFR-2, DR3, DR4, and DR5 (Tummers and Green, 2017). Up to now, the Fas/ FasL signaling pathway is considered as the most crucial signaling pathway in death receptor-mediated apoptosis. The corresponding mechanism is as follows: FAS is activated after binding with FasL. The activated Fas receptor recruits Fasassociated death domain protein (FADD) through the interaction of death domain (DD). FADD can not only bind Fas through DD at the C-terminal but also recruit procaspase- 8 
through N-terminal death effector domain and finally form Fas receptor-FADD-procaspase-8 death-inducing signaling complex (DISC). With the increase of the local concentration of DISC, procaspase- 8 can catalyze the formation of active caspase- 8 in DISC and then activate the downstream caspase factor, thus initiating the apoptosis process dependent on caspase cascade reaction (Wajant, 2002; Singh et al., 2016). Integral in the regulation and initiation of death receptor-mediated activation of programmed cell death is caspase- 8 (Tummers and Green, 2017). To escape exogenous apoptosis, cancer cells often downregulate the expression of death receptors by using antagonistic machinery (Friesen et al., 1997). Therefore, recovering Fas expression by drug intervention is anticipated to trigger cancer cell apoptosis.

It was observed that TSN could induce apoptosis by increasing the expression of Fas to inhibit hepatocellular carcinoma cells (He et al., 2010; Liu et al., 2016). In addition, for the ovarian cancer CAOV-3 and ES-2 cells, when treated with TSN, the expression of Fas and FasL increased firstly, subsequently followed by the activation of caspase- 8 and caspase-3. After the administration of z-IETD-FMK and z-DEVE-FMK (the inhibitors of caspase- 8 and caspase-3, respectively), the inhibitory effect of TSN on the proliferation of these cancer cells was reduced (Li et al., 2019). The increased expression of Fas, caspase-8, and caspase- 3 was also exhibited in leukemia K562 cells after incubation with TSN. Tumor necrosis factor (TNF)-related apoptosis-inducing ligand (TRAIL) is a promising anti-cancer agent that belongs to the TNF superfamily (Ashkenazi et al., 1999). Many cancer cells remain resistant to receptor-mediated apoptosis-for instance, the TRAIL-mediated apoptotic resistance appears in non-small-cell lung carcinoma, and the TSN showed a sensitivity-enhanced ability for cancer cell apoptosis. The underlying apoptotic mechanisms involved the upregulation of death receptor 5 (DR5) mediated by CCAAT/enhancer binding protein homologous protein (Li et al., 2017). Consistently, the upregulated expression of DR5 was found in TRAIL inhibiting hepatocellular carcinoma.

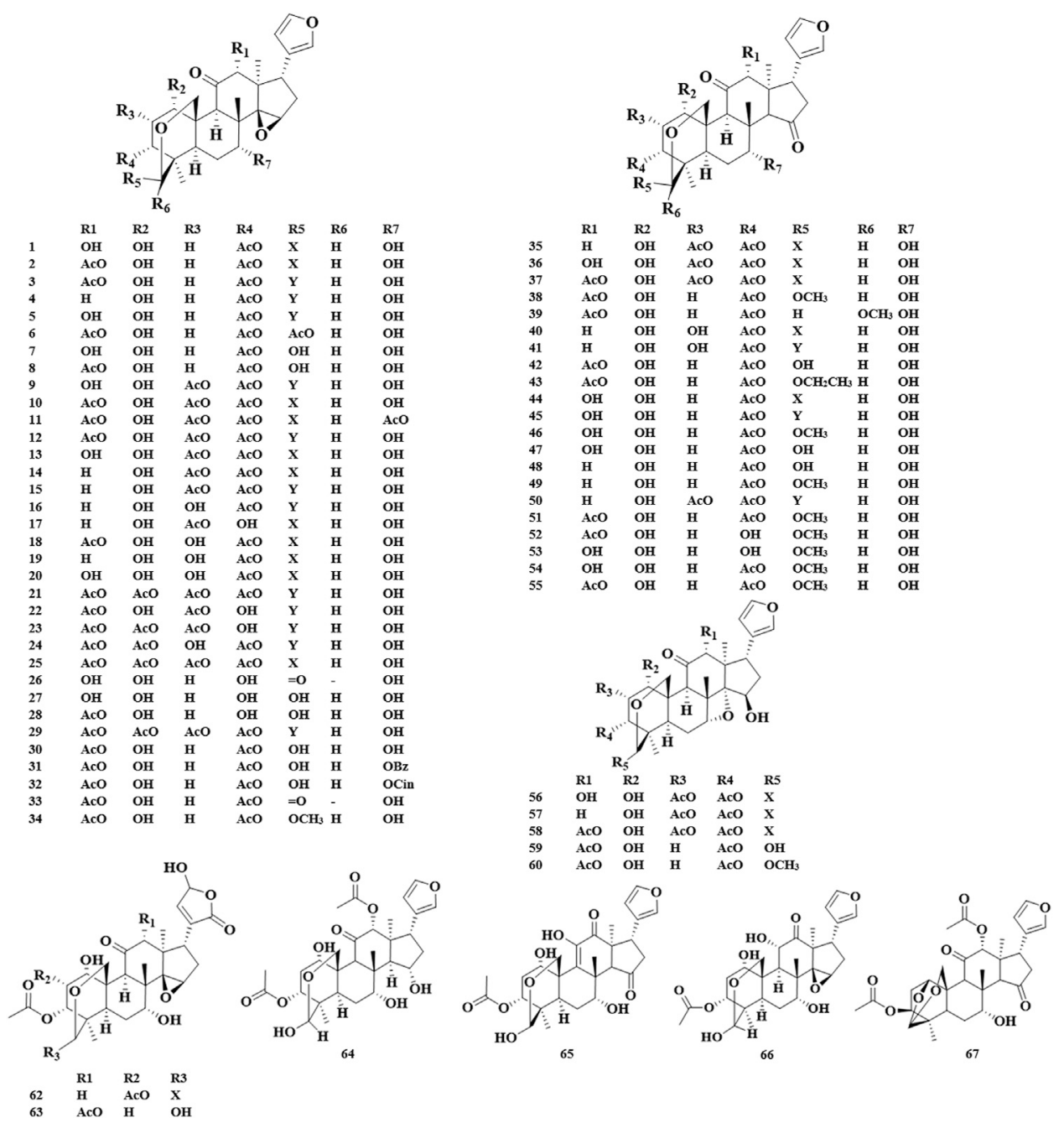

FIGURE 2 | Structures of trichilin class limonoids 1-67. 


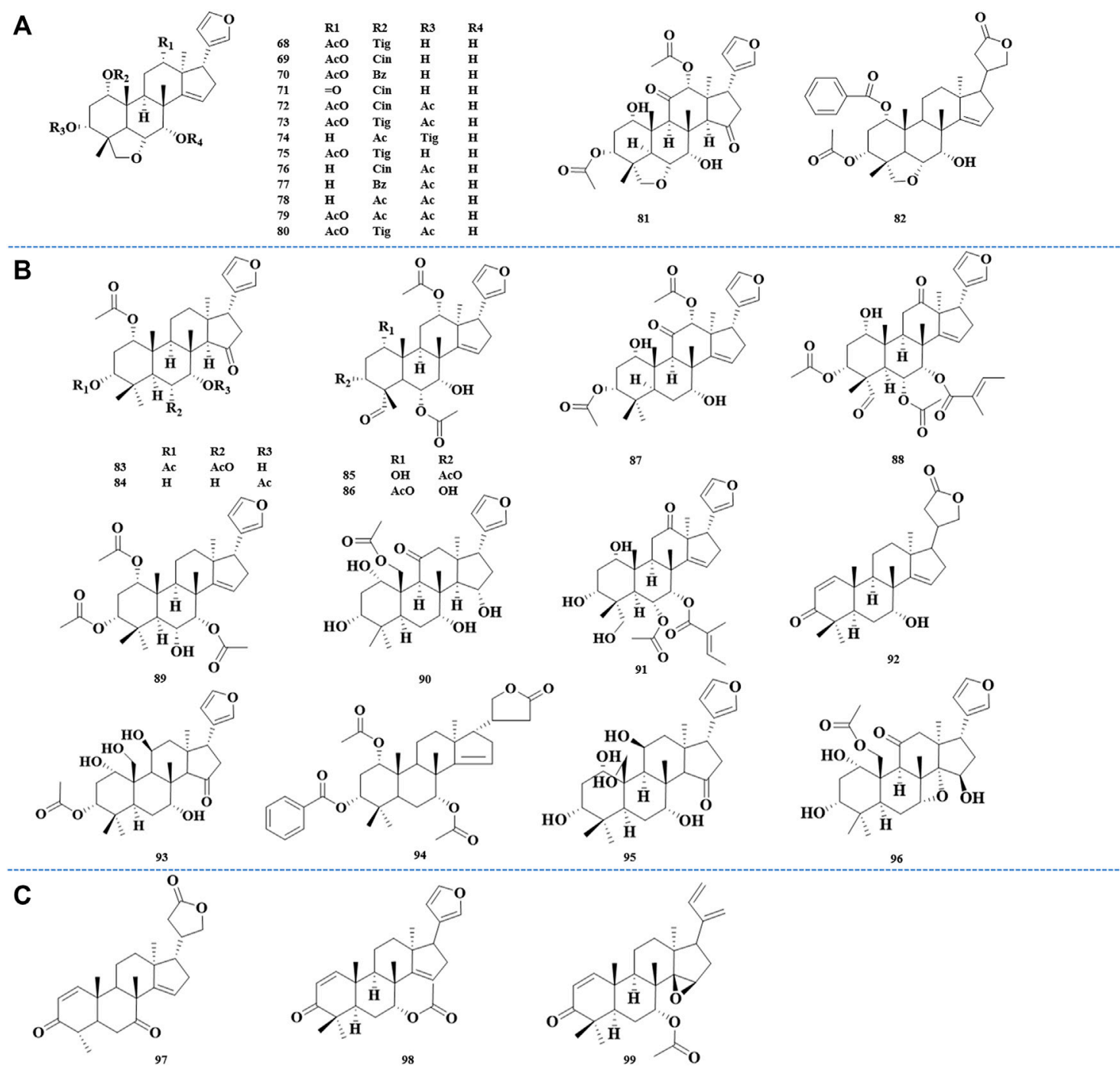

FIGURE 3 | Structures of vilasinin class limonoids 68-82 (A), structures of havanensin class limonoids 83-96 (B), and structures of azadirone class limonoids $97-99$ (C)

Other Mechanisms of Apoptosis

Recently, intracellular calcium ion $\left(\mathrm{Ca}^{2+}\right)$ has been regarded to play a vital role in cell apoptosis, and $\mathrm{Ca}^{2+}$ overload was considered as the common final pathway of all types of cell death (Rizzuto et al., 2003). $\mathrm{Ca}^{2+}$ can induce apoptosis through regulating apoptosis-related molecules, producing reactive oxygen species (ROS), and changing cell membrane permeability (Orrenius et al., 2003). Shi et al. reported that TSN had an inhibitory effect on neuroblastoma glioma NG108-15 cells. Since TSN cannot penetrate the lipid bilayer, it was found that TSN exerted the anti-cancer role by facilitating the $\mathrm{Ca}^{2+}$ channel of the cell membrane (Hu et al., 1997). In order to further confirm which $\mathrm{Ca}^{2+}$ channel was regulated by TSN, a series of physiological experiments was carried out. These findings showed that TSN could facilitate the L-type $\mathrm{Ca}^{2+}$ channel in the cell membrane, thus promoting extracellular
$\mathrm{Ca}^{2+}$ influx. In addition, intracellular $\mathrm{Ca}^{2+}$ overload can directly induce apoptosis ( $\mathrm{Li}$ and Shi, 2004). It was reported that TSN, at different concentrations, could cause different changes to the $\mathrm{PC} 12$ cells, and these distinctions were closely related with the increase of $\left[\mathrm{Ca}^{2+}\right]_{i}$, which indicated that $\mathrm{Ca}^{2+}$ played an essential role in cell apoptosis (Li and Shi, 2005).

Moreover, TSN can trigger some different pathways to induce cancer cell apoptosis. In one study, TSN was proven as a candidate of novel anti-cancer drugs for glioblastoma, and the underlying mechanism was inducing estrogen receptor $\beta$ - and p53-mediated apoptosis (Cao et al., 2016). In addition, the c-Jun $\mathrm{N}$-terminal kinase (JNK) signaling pathway was also involved in TSN-induced apoptosis. In a representative study, TSN was found to induce apoptosis by suppressing the CDC42/ MEKK1/JNK pathway in human promyelocytic leukemia HL60 cells (Ju et al., 2013). Furthermore, the PI3K-Akt signaling 
A

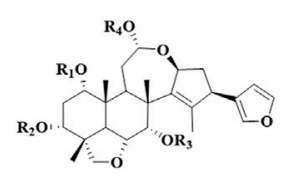

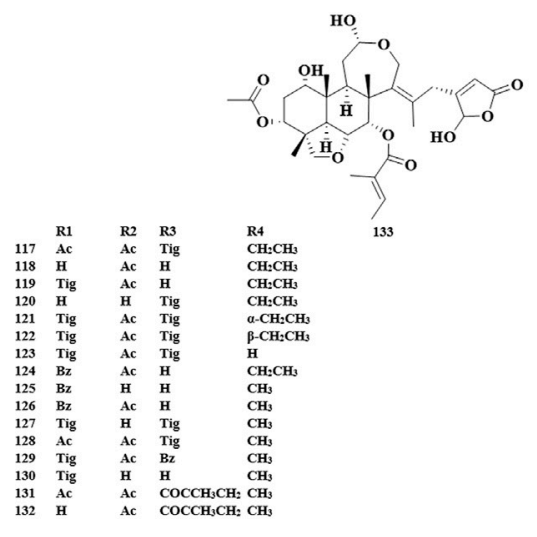

B

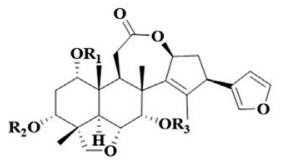

$\begin{array}{llll} & \text { R1 } & \text { R2 } & \text { R3 } \\ 134 & \text { Ac } & \text { Ac } & \text { Bz } \\ 135 & \text { Ac } & \text { Ac } & \text { Tig } \\ 136 & \text { Ac } & \text { COCH(CH)) } & \text { Tig } \\ 137 & \text { Tig } & \text { Ac } & \text { Tig } \\ 138 & \text { Bz } & \text { Ac } & \text { Tig } \\ 139 & \text { Tig } & \text { Ac } & \text { Bz } \\ 140 & \text { H } & \text { Ac } & \text { Tig } \\ 141 & \text { H } & \text { Ac } & \text { Bz } \\ 142 & \text { Ac } & \text { H } & \text { Tig }\end{array}$

C

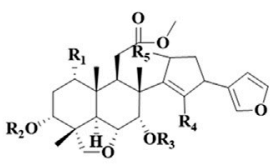

$\begin{array}{lllll} & \mathrm{R1} & \mathrm{R2} & \mathrm{R3} & \mathrm{R} 4 \quad \mathrm{R} 5 \\ 143 & \mathrm{X} & \mathrm{Ac} & \mathrm{Tig} & \mathrm{AcO} \mathrm{CH}_{3} \\ 144 & \mathrm{OTig} & \mathrm{Ac} & \mathrm{Tig} & \mathrm{AcO} \mathrm{CH}_{3} \\ 145 & \mathrm{AcO} & \mathrm{Ac} & \mathrm{COCH}\left(\mathrm{CH}_{3}\right) \mathrm{CH}_{3} \mathrm{CH}_{3} \\ 146 & \mathrm{AcO} & \mathrm{Ac} & \mathrm{COCH}\left(\mathrm{CH}_{3}\right) & \mathrm{CH}_{3} \mathrm{AcO}_{3} \\ 147 & \mathrm{AcO} & \mathrm{Ac} & \mathrm{Tig} & \mathrm{CH}_{3} \mathrm{AcO} \\ 148 & \mathrm{AcO} & \mathrm{Ac} & \mathrm{Bz} & \mathrm{CH}_{3} \mathrm{OCH} \\ 149 & \mathrm{AcO} & \mathrm{Ac} & \mathrm{Tig} & \mathrm{CH}_{3} \quad \mathrm{OCH}_{3} \\ 150 & \mathrm{AcO} & \mathrm{Ac} & \mathrm{Tig} & \mathrm{CH}_{3} \mathrm{OH}\end{array}$

FIGURE 4 | Structures of nimbolinin class limonoids 100-133 (A), structures of ohchinolide class limonoids 134-142 (B), and structures of nimbolidin class limonoids 143-150 (C).

pathway acted a crucial role in apoptosis, and excessive activation of PI3K/Akt signaling in cancer cells was involved in the development of multidrug resistance (Burris, 2013). It was observed that TSN could reverse the resistance of human breast cancer cells $4 \mathrm{~T} 1$ to adriamycin by inhibiting the PI3K/ Akt signaling pathway (Wang et al., 2018). Recently, the role of microRNAs (miRNAs) in the treatment of cancer by TSN was explored. The outcomes showed that TSN could inhibit glioma progression property and induce apoptosis via upregulating the expression of miR-608 and downregulating the expression of miR-608 targets, Notch1 and Notch2, in glioma (Wang Q. et al., 2020).

\section{Effect of Toosendanin on Tumor Invasion and Metastasis}

About $90 \%$ of cancer-related deaths are associated with metastatic diseases rather than primary tumors (Jafri et al., 2017). Emerging evidence showed that TSN could inhibit cancer invasion and metastasis (Pei et al., 2017; Wang et al., 2017; Luo et al., 2018; Wang Q. et al., 2020). The migration and invasion of tumor cells is a complex process of multiple factors, stages, and steps. It involves the process of epithelial-mesenchymal transition (EMT), the degradation of basement membrane and extracellular matrix, the decrease of tumor cell adhesion, and angiogenesis. Among these pathological processes, EMT acts a pivotal role, and its function is transforming the polarized epithelial cell into the mesenchymal cell phenotype. E-cadherin is a marker of epithelial cells, which maintains the integrity of tissue structure by regulating the adhesion reaction between cells and matrix or between cells. Mesenchymal proteins such as $\mathrm{N}$-cadherin and vimentin are highly expressed with the decrease of E-cadherin expression, which collaboratively induces the EMT process (Sachdeva and Mo, 2010). In the transforming growth factor- $\beta 1$ (TGF- $\beta 1$ )-induced EMT cell model, the inhibitory effect of TSN on A549 and H1975 lung cancer cell migration, invasion, and adhesion was evaluated by wound healing, transwell, and adhesion assays. The outcomes indicated that TSN could weaken the abilities mentioned above, decrease the expression of $\mathrm{N}$-cadherin, vimentin, and $\mathrm{p}-\mathrm{ERK} 1 / 2$, and increase the expression of E-cadherin. Besides these, TGF- $\beta 1$-induced EMT biomarkers can be reversed by silence Snail. These results demonstrated that TSN significantly inhibited TGF- $\beta 1$ induced EMT and migration, invasion, and adhesion through the ERK/Snail pathway in lung cancer cells (Luo et al., 2018). Consistently, in CAVO-3 human ovarian cancer cells, invasion and migration could be inhibited by TSN, followed by increased NF- $\kappa \mathrm{B}$ and E-cadherin and decreased $\mathrm{N}$-cadherin, vimentin, and Snail. The underlying mechanism 


\section{A}

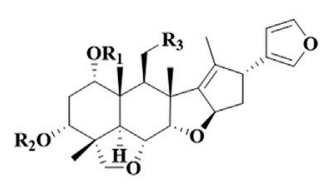

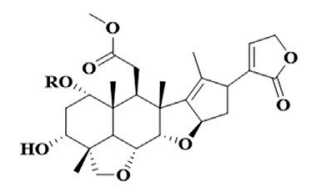

$\begin{array}{llll} & \text { R1 } & \text { R2 } & \text { R3 } \\ 151 & \text { Cin } & \text { Ac } & \text { CHO } \\ 152 & \text { Tig } & \text { Ac } & \text { CHO }\end{array}$

$\begin{array}{llll}151 & \text { Cin } & \text { Ac } & \text { CHO } \\ 152 & \text { Tig } & \text { Ac } & \text { CHO } \\ 153 & \text { Tig } & \text { Ac } & \text { COOCH } \\ 154 & \text { Tig } & \text { H } & \text { COOCH }\end{array}$

$\begin{array}{llll}153 & \text { Tig } & \text { Ac } & \text { COOCH } \\ 154 & \text { Tig } & \text { H } & \text { COOCH } \\ 155 & \text { Bz } & \text { Ac } & \text { CHO }\end{array}$

$\begin{array}{llll}154 & \mathrm{Tig} & \mathrm{H} & \mathrm{COOCH} \\ 155 & \mathrm{Bz} & \mathrm{Ac} & \mathrm{CHO} \\ 156 & \mathrm{Cin} & \mathrm{H} & \mathrm{COOCH_{3 }} \\ 157 & \mathrm{Bz} & \mathrm{H} & \mathrm{COOCH}_{3} \\ 158 & \mathrm{COC}\left(\mathrm{CH}_{3}\right)=\mathrm{CH}_{2} & \mathrm{H} & \mathrm{COOCH} \\ 159 & \mathrm{Tig} & \mathrm{Tig} & \mathrm{COOCH}_{3}\end{array}$

$\begin{array}{llll}158 & \mathrm{COC}\left(\mathrm{CH}_{3}\right)=\mathrm{CH}_{2} & \mathrm{H} & \mathrm{COOCH}_{3} \\ 159 & \mathrm{Tig} & \mathrm{Tig} & \mathrm{COOCH}_{3} \\ 160 & \mathrm{X} & \mathrm{Ac} & \mathrm{COOCH}_{3} \\ 161 & \mathrm{CH}_{2} \mathrm{CH}\left(\mathrm{CH}_{3}\right)_{2} & \mathrm{Ac} & \mathrm{COOCH}_{3}\end{array}$

$\begin{array}{llll}161 & \mathrm{CH}_{2} \mathrm{CH}\left(\mathrm{CH}_{3}\right) 2 & \mathrm{Ac} & \mathrm{AOOCH} \\ 162 & \mathrm{Cin} & \mathrm{Ac} & \mathrm{COOCH}_{3}\end{array}$

но“

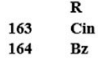

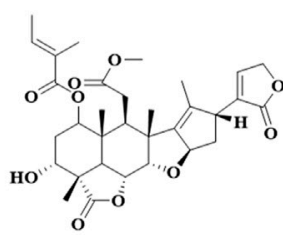

171

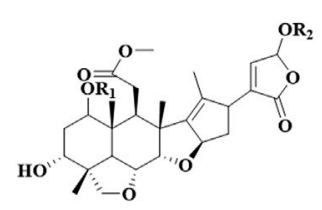

$$
\begin{array}{lll} 
& \mathrm{R} 1 & \mathrm{R} 2 \\
165 & \mathrm{Cin} & \mathrm{H} \\
166 & \mathrm{Cin} & \mathrm{CH} 3 \\
167 & \mathrm{Bz} & \mathrm{H}
\end{array}
$$

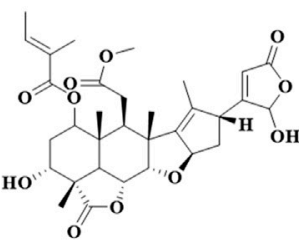

172

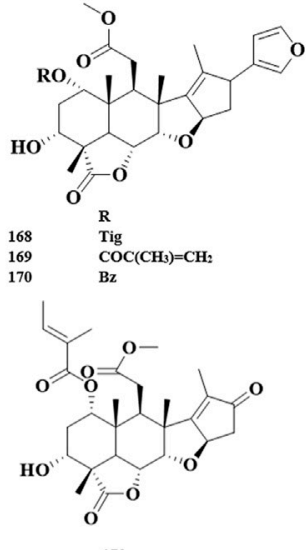

173

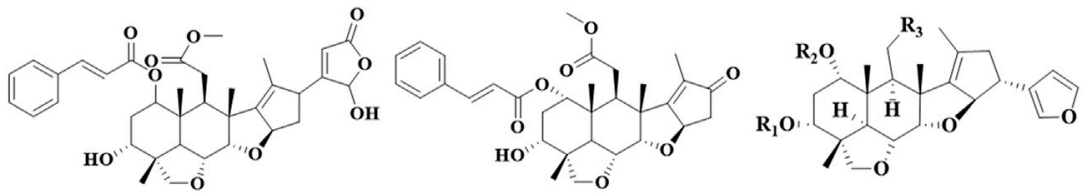

174

175

$\begin{array}{llll}176 & \text { R1 } & \text { R2 } & \text { R3 } \\ \text { H } & \text { Tig } & \text { CHO }\end{array}$
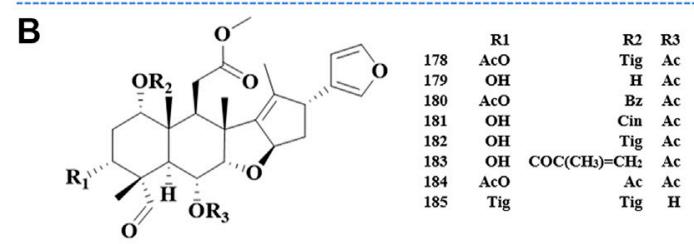

C

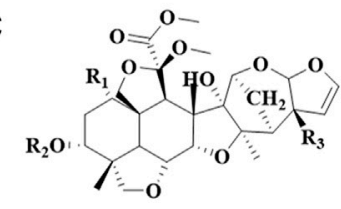

$\begin{array}{llll} & \text { R1 } & \text { R2 } & \text { R3 } \\ 187 & \text { OTig } & \text { H } & \text { AcO } \\ 188 & \text { H } & \text { Tig } & \text { AcO } \\ 189 & \text { H } & \text { COC }\left(\mathrm{CH}_{3}\right)=\mathrm{CH}_{2} & \text { AcO } \\ 190 & \text { H } & \text { Ac } & \text { AcO } \\ 191 & \text { OTig } & \text { Ac } & \text { AcO } \\ 192 & \text { OCin } & \text { Ac } & \text { OH } \\ 193 & \text { AcO } & \text { Tig } & \text { OH } \\ 194 & \text { OTig } & \text { Ac } & \text { OH }\end{array}$

\begin{tabular}{ll} 
R3 & \\
AcO & $\mathbf{1 9 5}$ \\
AcO & $\mathbf{1 9 6}$ \\
AcO & 197 \\
AcO & 198 \\
AcO & $\mathbf{1 9 9}$ \\
OH & $\mathbf{2 0 0}$ \\
OH & $\mathbf{2 0 1}$ \\
OH & $\mathbf{2 0 2}$ \\
\hline
\end{tabular}

$\begin{array}{lll} & \text { R1 } \\ 195 & \text { OH } \\ 196 & \text { H } \\ 197 & \text { AcO } \\ 198 & \text { AcO } \\ 199 & \text { OCOC(CH3) } \mathrm{CH}_{2} \\ 200 & \text { Y } \\ 201 & \text { OCin } \\ 202 & \text { H }\end{array}$

$\begin{array}{ll}\mathrm{R} 2 & \mathrm{R3} \\ \mathrm{Tig} & \mathrm{OH} \\ \mathrm{Tig} & \mathrm{OH} \\ \mathrm{COCH}\left(\mathrm{CH}_{3}\right) \mathrm{CH}_{2} \mathrm{CH}_{3} \mathrm{AcO} \\ \mathrm{Aig} & \mathrm{AcO} \\ \mathrm{Ac} & \mathrm{OH} \\ \mathbf{A c} & \mathrm{OH} \\ \mathbf{H} & \mathrm{OH} \\ \text { Met } & \text { OH }\end{array}$

FIGURE 5 | Structures of salannin class limonoids 151-177 (A), structures of ohchinolal class limonoids 178-186 (B), and structures of meliacarpinin class limonoids 187-202 (C).

may be related with the NF- $\mathrm{KB} /$ Snail pathway (Li et al., 2018b). Recently, the $\beta$-catenin pathway has been considered as the crucial signaling pathway involved in EMT and plays an important role in metastasis. TSN was confirmed to inhibit migration, invasion, and TGF- $\beta 1$ induced EMT via miR-200a-mediated downregulation of the $\beta$-catenin pathway in SGC-7901 human gastric carcinoma cells (Wang et al., 2017). Furthermore, TGF- $\beta 1$ induced EMT and morphological change in pancreatic cancer cells can be reversed through upregulating E-cadherin expression and decreasing vimentin, ZEB1, and Snail levels. The corresponding mechanism was involved with blocking the Akt/mTOR signaling pathway (Pei et al., 2017).

\section{Synergistic Effect of Toosendanin in Chemotherapy}

Since the majority of chemotherapy drugs have serious side effects, it is still urgent to take adjuvant therapy to reduce the dosage of chemotherapy drugs and improve their anti-tumor activity. As a representative chemotherapy drug, cisplatin is used to treat non-small cell lung cancer (NSCLC), but due to the development of resistance, the benefit has been limited. It was found that TSN can enhance cisplatin sensitization against non-small cell lung cancer cells through targeting Anxa4 in NSCLC cells, decreasing the combination of Anxa4 with ATP7A, and decreasing the extracellular efflux of platinum. The results showed that TSN could be a potential candidate in treating drug-resistant NSCLC cells (Zheng et al., 2018). Adriamycin (ADM) is an anti-cancer drug with a high frequency of use in the treatment of breast cancer. Nevertheless, some kinds of breast cancer or breast cancers under repeated ADM exposure develop a strong resistance to ADM, which limits its clinical efficacy. Wang et al. found that TSN can attenuate the resistance of human breast cancer cells to ADM by inhibiting the expression of $\mathrm{ABCB} 1$ and PI3K/Akt signaling (Wang et al., 2018). Doxorubicin, another anticancer antibiotic, possesses a strong anti-tumor effect. 

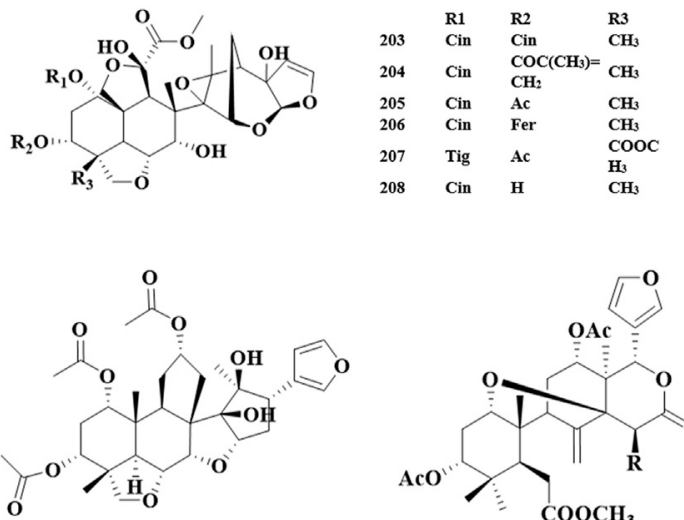

211

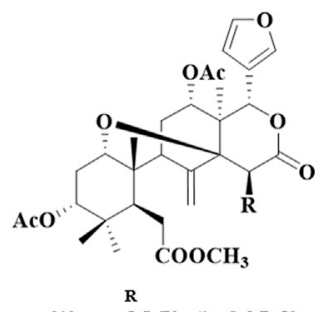

212

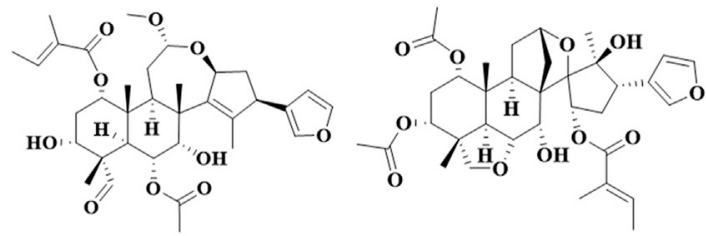

209

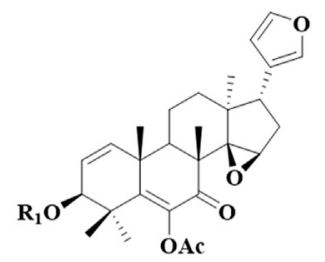

R
210

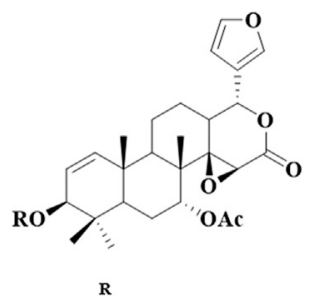

FIGURE 6 | Structures of meliacarpin class limonoids 203-208 (A) and structures of other-class limonoids 209-214 (B). Rha, rhamnose; Glc, clucose; Ara, arabinose.

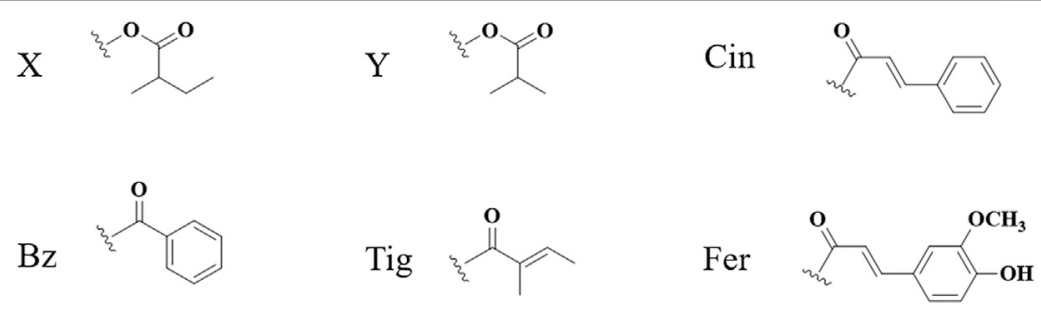

FIGURE 7 | Abbreviation of structure.

However, the toxicity of high-dose doxorubicin is severe, especially to the heart. In MDA-MB-435 breast cancer cells, cotreatment of doxorubicin with TSN can significantly enhance the anti-breast cancer activity, and the mechanism may depend on the FoxO1-Bim/Noxa pathway.

\section{Selective Inhibition Effect of Toosendanin on Tumor Cells}

The specific inhibitory effect on tumors is crucial for the development of new anti-tumor drugs. In one study, $\mathrm{Li}$ et al. showed that TSN selectively increased the sensitivity of NSCLC cells, but not normal cells (293T, BEAS-2B, HBE, L02, and PBMC), to TRAIL-induced apoptosis (Li et al., 2017). For the toxicity of hepatocellular carcinoma, after treating with toosendanin $(0.5 \mu \mathrm{M})$ for $72 \mathrm{~h}$, the inhibition rate for SMMC7721 and Hep3B cells was 56 and 42\%, respectively, and for IAR-20 and L02 cells (normal liver cell lines), it was 21 and $20 \%$, respectively (He et al., 2010). When treated with a lower dosage range $(0.25-1 \mu \mathrm{M})$, toosendanin could selectively kill human gastric carcinoma cells (MGC-803, BGC-823, HGC-27, AGS, SGC-7901, and MKN-45) rather than normal human gastric epithelial cells (GES-1) (Wang et al., 2017). The selective inhibition effect of toosendanin against tumor cells was cross-validated in different research groups. According to the results of Yan and Zhang, the $\mathrm{IC}_{50}$ of toosendanin on normal primary hepatocyte cells was 30.65 and $14.94 \mu \mathrm{M}$, respectively, which was higher than its suppressing effect on hepatocellular carcinoma $(0.5-0.9 \mu \mathrm{M})$ as reported by other teams (Zhang et al., 2008; He et al., 2010; Liu et al., 2016; Yan et al., 2019).

\section{Anti-tumor Effects of Other Limonoids}

Inspired by the remarkable bioactivity, numerous works have been conducted to isolate and identify the potential lead compounds from genus Melia plants for cancer treatment. Three limonoids, including trichilinin B, 3-deacetyl-4'demethyl-28-oxosalannin, and 23-hydroxyohchininolide, were cytotoxic to gastric cancer cell line of $\mathrm{AZ} 521$ with $\mathrm{IC}_{50}$ values of 58.2, 3.2, and $78.5 \mu \mathrm{M}$, respectively (Pan et al., 2014b). In another study, 31 limonoids were isolated and identified from the fruits of $M$. azedarach; among them, several compounds including meliarachin C, 12-dehydroneoazedarachin D, salannin, 1-O-decinnamoyl-1-O-benzoylohchinin, ohchininolide, 1-O-decinnamoyl-1-O-benzoylohchininolide, 23-hydroxyohchininolide, 1-O-decinnamoyl-1-O-benzoyl-23hydroxyohchininolide,1-O-decinnamoyl-1-O-benzoyl-28oxoohchinin, mesendanin E, 1-benzoyl-1-detigloylohchinolal, 

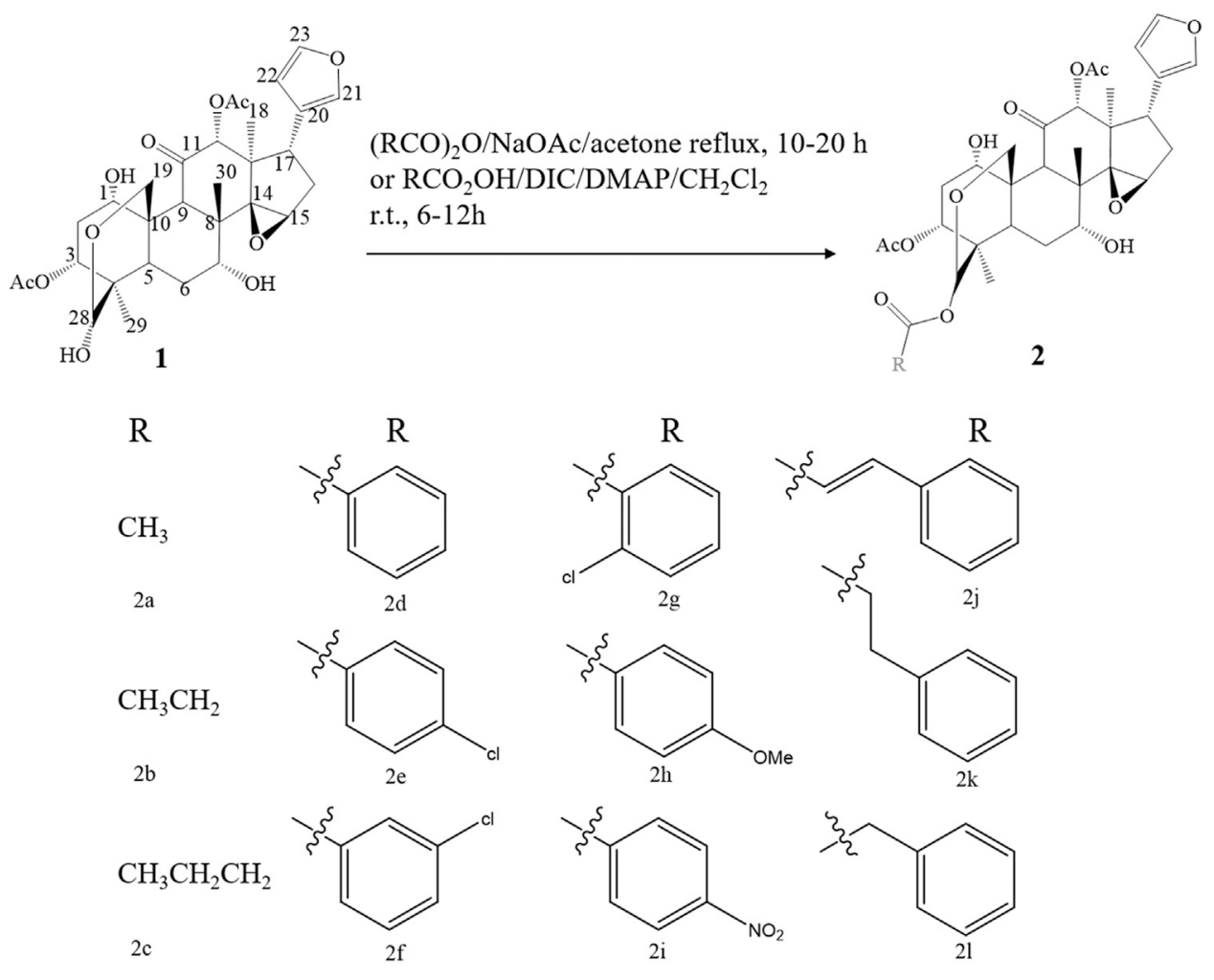

FIGURE 8 | The synthetic route of 28-acyloxy derivatives of toosendanin.

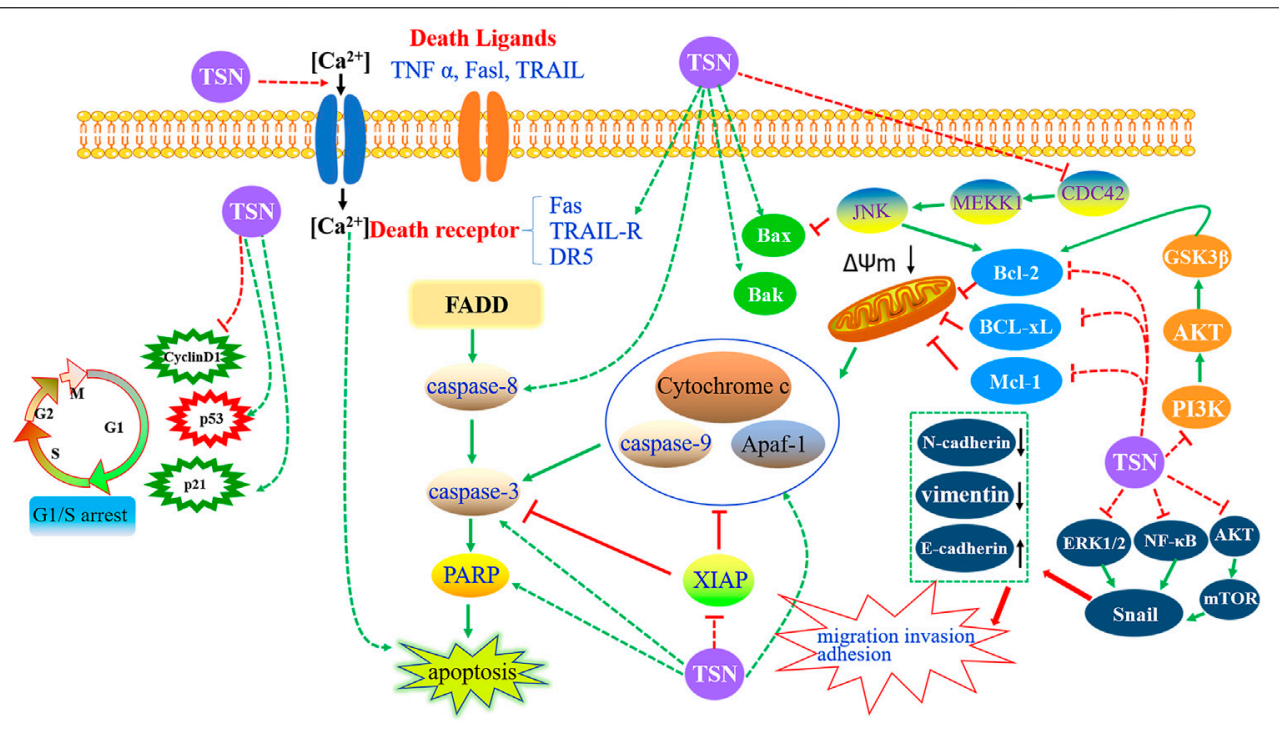

FIGURE 9 | Targeting the apoptosis signaling pathways by toosendanin in cancers.

and nimbolinin D possessed anti-tumor effect against AZ521 cells, and 12-dehydroneoazedarachin $\mathrm{D}$ showed the most potent cytotoxicity with an $\mathrm{IC}_{50}$ value of $11.8 \mu \mathrm{M}$ (Akihisa et al., 2013). In addition, trichilinin $\mathrm{E}$ exhibited apparent cytotoxicity against the gastric cancer cell line SGC-7901 (Zhou et al., 2016).
For lung cancer treatment, 12-hydroxyamoorastatone, 12hydroxyamoorastatin, 12-acetoxyamoorastatin, meliarachin $\mathrm{C}, 1-\mathrm{O}$ decinnamoyl-1-O-benzoylohchinin, 1-O-decinnamoyl-1-O-benzoyl23-hydroxyohchininolide, and 1-benzoyl-1-detigloylohchinolal were reported to be toxic against A549 cell, and 1,12-diacetyltrichilin B 
showed significant cytotoxicity with an $\mathrm{IC}_{50}$ value of $0.93 \mu \mathrm{M}$ (Tada et al., 1999; Zhao et al., 2012; Akihisa et al., 2013). The isolated limonoids can also inhibit colorectal cancers. Among them, 12hydroxyamoorastatone, 12-hydroxyamoorastatin, and 12acetoxyamoorastatin displayed obvious antitumor activity against HCT-15 cell. Notably, 12-acetoxyamoorastatin possessed stronger cytotoxicity than antimycin A (positive drug), which indicated that it could be a candidate in curing colorectal cancer (Ahn et al., 1994). The anti-tumor effect was also found in SW480 colorectal cancer cells by 1,12-diacetyltrichilin B (Yuan et al., 2013). It was reported that lots of limonoids have a cytotoxic effect on leukemia HL-60 cells. Among them, 3-deacetyl-4'-demethyl-28-oxosalannin, 1,12-diacetyltrichilin B, meliarachin C, 1-O-cinnamoyltrichilinin, 23methoxyohchininolide A, 1-benzoyl-1-detigloylohchinolal, 1cinnamoyl-1-detigloylohchinolal, and nimbolinin $\mathrm{D}$ were considered as the most potential compounds with an $\mathrm{IC}_{50}$ value lower than $10 \mu \mathrm{M}$ (Zhao et al., 2012; Akihisa et al., 2013; Pan et al., 2014b). Simultaneously, 12 limonoids from the fruits of $M$. azedarach also possessed marked anti-tumor activity against breast cancer MCF7 cell with $\mathrm{IC}_{50}$ values from 0.06 to $94.8 \mu \mathrm{M}$ (Akihisa et al., 2013). Toosendansin $\mathrm{H}$, meliatoxin $\mathrm{B} 1$, and 1,12-diacetyltrichilin $\mathrm{B}$, which were isolated from the fruits and stem bark of $M$. toosendan, were toxic to MCF-7 cell (Zhao et al., 2012; Li et al., 2020b). Moreover, trichilinin $\mathrm{B}$ and 21-hydroxyisoohchininolide can inhibit the growth of SK-BR-3 cell, which is another type of breast cancer cell (Pan et al., 2014b).

MTT assay was applied to evaluate the cytotoxicity of nine limonoids against lymphoma P388 cell. The outcomes revealed that all the nine limonoids possessed apparent toxicity, of which 12-deacetyltrichilin I, 3-deacetyltrichilin $\mathrm{H}$, and trichilin $\mathrm{D}$ exhibited significant bioactivity with $\mathrm{IC}_{50}$ values of 0.011 , 0.045, and $0.055 \mu \mathrm{g} / \mathrm{ml}$, respectively (Takeya et al., 1996b). In the treatment of oral epithelial carcinoma, trichilin $\mathrm{H}\left(\mathrm{IC}_{50}=\right.$ $0.11 \mu \mathrm{g} / \mathrm{ml})$ and $12-O$-methylvolkensin $\left(\mathrm{IC}_{50}=8.72 \mu \mathrm{g} / \mathrm{ml}\right)$ were observed to be toxic to $\mathrm{kB}$ cells (Tada et al., 1999). Zhou et al. isolated three new C-seco limonoids and one new tetracyclic limonoid from the fruits of $M$. azedarach, and their cytotoxicity against cervical cancer HeLa S3 cells was assessed. The results showed that 15-O-deacetylnimbolidin $\mathrm{B}$ and 12-Odeacetyltrichilin $\mathrm{H}$ had a strong inhibitory effect, while 15-Odeacetyl-15-O-methylnimbolidin $\mathrm{A}$ and 15-O-deacetyl-15$O$-methylnimbolidin B had weak cytotoxicity (Zhou et al., 2005). Furthermore, using bioassay-guided chemical investigation, 12-hydroxyamoorastatone, 12hydroxyamoorastatin, and 12-acetoxyamoorastatin were isolated, and the anti-tumor effects were evaluated. Three compounds showed potent cytotoxicity against human malignant melanoma SK-MEL-2 and human CNS carcinoma XF498 (Ahn et al., 1994). Several limonoids also possessed noticeable hepatotoxicity. Among them, 12-ethoxynimbolinins $\mathrm{G}$ and 1,12-diacetyltrichilin B were toxic to SMMC-7721 cells, with $\mathrm{IC}_{50}$ values of 27.6 and $0.36 \mu \mathrm{M}$, respectively, and trichilinin E had cytotoxicity against HepG2 cell (Yuan et al., 2013; Zhou et al., 2016; Zhang et al., 2018).

\section{Structure-Activity Relationships With Anti-tumor}

In order to further explain the effect of different skeletons and substituents on the anti-tumor activities of limonoids, the corresponding structure-activity relationships (SAR) were systematically summarized. For trichilin-type limonoids, it was found that meliarachin $C$ and toosendanin with a $\beta$ oriented epoxy ring at C-14/C-15 possessed a significant bioactivity than those of their 15-oxo analogues (meliarachin K and meliarachin G) against HL60 and AZ521 cells. Meanwhile, the inhibitory effect of 15-oxo trichilins against HL60 and AZ521 cells could be enhanced by deacetoxylation at C-12 (12-dehydroneoazedarachin D vs. meliarachin K). For vilasanin-type limonoids, acetylation of the hydroxy group at C-3 was able to strengthen the anticancer effect against HL60 cells-for instance, 1-Ocinnamoyltrichilinin $\left(\mathrm{IC}_{50}=5.8 \mu \mathrm{M}\right)$ vs. trichilinin $\mathrm{D}\left(\mathrm{IC}_{50}\right.$ $=61.2 \mu \mathrm{M})$. This structural modification also enhanced the activity against HL60 cells in the salannin-type limonoids with a cinnamoyl group at C-1 (ohchinin acetate $v s$. ohchinin). By contrast, acetylation at C-3 could reduce the bioactivity of salannin-type limonoids, which bore a tigloyl group at C-1 (salannin vs. 3-O-deacetylsalannin). In addition, the substitution of a methacrylic group at C-1 with a benzoyl group reduced the activity against HL60 and AZ521 cells (3deacetyl-4' -demethyl-28-oxosalannin vs. 1-O-decinnamoyl-1O-benzoyl-28-oxoohchinin). The characteristic SAR was also found in ohchinolal-type limonoids. The study showed that the inhibitory properties against HL60 cells would be reduced when the cinnamoyl group at $\mathrm{C}-1$ was substituted by a methacrylic or a tigloyl group (1-cinnamoyl-1detigloylohchinolal $v s$. mesendanin $\mathrm{E}$ and ohchinolal) (Akihisa et al., 2013). Surprisingly, the demethacrylation of mesendanin $\mathrm{E}$ and the detigloylation of ohchinolal at C-1 were able to enhance the anti-cancer ability against HL60, A549, and AZ521 cells. This finding indicated that substitution of methacrylic or tigloyl group at C-1 was probably related with anti-cancer property (Pan et al., 2014a) (Figures 10).

\section{Antifeeding and Insecticide Effects Antifeeding and Insecticide Effects of Toosendanin}

$M$. toosendan and $M$. azedarach, two common agricultural insecticidal and Ascaris-repellent Chinese herbs, have been recorded in ancient China, and TSN has been considered as the main active compound for insecticidal effect. The content of TSN in M. toosendan is high, and it is environmentally friendly due to its botanical property (Shi and Li, 2007). Recently, TSN showed distinguished potential in the field of agricultural anthelmintic. It was reported that TSN possessed remarkable repellent and insecticidal effects on Pieris rapae, and the underlying mechanism has been explored comprehensively. TSN also has obvious antifeedant activity. TSN at different dosages can affect the feeding reaction and feeding speed of $P$. rapae, which exhibited different poisoning symptoms. A high dose of TSN can induce the paralysis and coma of $P$. rapae and cause pathological changes of the midgut. Meanwhile, a low dose of TSN can transform the larvae into abnormal insects. One study was designed to evaluate the effects of TSN on the activities of several important enzymes in $P$. rapae. The results showed that TSN was able to reduce the activities of microsomal multifunctional oxidase, protease, and intestinal acetylase, 
which indicated that the interference of TSN on the detoxification enzymes of $P$. rapae may be responsible for the toxic reaction (Zhang and Zhao, 1992a). In addition, TSN was capable of causing severe damage to midgut tissue, resulting in abscission and autolysis (Zhang and Zhao, 1991). Furthermore, the physiological metabolism of $P$. rapae was disturbed by TSN, and abnormal biological oxidation was induced in vivo, which demonstrated that TSN could inhibit the central nervous system of the larva (Zhang et al., 1992b).

Apart from P. rapae, TSN possessed potent growth inhibition on other species of insects-for instance, TSN possessed strong stomach toxicity against Mythimna separate $\left(\mathrm{LC}_{50}=252.23 \mu \mathrm{g} /\right.$ $\mathrm{ml}$ ), and this process was located and targeted on the microvilli of the midgut cells. Subsequently, TSN induced the destruction of midgut epithelial cells, which caused the regurgitation, paralysis, and death of M. separate (Li H. et al., 2020). Another research reported that TSN could disrupt yolk deposition in oocytes, blood ingestion and digestion, and ovary ecdysteroid production in Aedes aegypti (Ma et al., 2013). Huang et al. found that the activities of pepsase and tryptase in Brachionus plicatilis can be suppressed by TSN, which may be responsible for the feeding deterrent property (Huang et al., 2017). In order to solve the problems of biological pollution in the cultivation scale of microalgae, TSN was selected to conduct an insecticidal test. The outcomes revealed that TSN possessed obvious toxicity to Stylonychia mytilus (a type of ciliate), while it is relatively safe to Chlorella pyrenoidosa (a type of microalgae) (Xu et al., 2019). Moreover, TSN was reported to inhibit the growth of Sirophilus oryzae and Cryptolestes ferrugineus, two common store-product insects (Xie et al., 1995). In addition to the control of agricultural pests, TSN has become a clinical anti-Ascaris drug in China since the 1950s (Shi and Li, 2007).

\section{Antifeeding and Insecticide Effects of Other Limonoids}

The insect antifeedant activities of other limonoids from genus Melia plants have been extensively evaluated, and the structure-activity relationships were also discussed. By using the conventional leaf disk method, the antifeedant activity against Spodoptera eridania was tested for ohchinolide C, salannin, nimbolidin $B$, nimbolidin $C$, nimbolidin $D$, nimbolidin $\mathrm{E}$, and nimbolidin $\mathrm{F}$. The outcomes showed that these compounds, at a concentration of $500 \mathrm{ppm}$, can significantly affect feeding (Nakatani et al., 1996; Zhou et al., 1997), while trichilinin B, trichilinin C, ohchinolide B, ohchinolide $\mathrm{C}$, and 3-O-acetylohchinolal exhibited a weak antifeedant activity against $S$. eridania at a concentration of $1,000 \mathrm{ppm}$ (Nakatani, 1999). At the concentration of $400 \mathrm{ppm}$, 12-O-acetylazedarachin A, 12-O-acetylazedarachin B, trichilin $\mathrm{H}$, trichilin I, trichilin J, trichilin $\mathrm{K}$, and trichilin $\mathrm{L}$ have an inhibitory effect on the feeding amounts of leaf compared to the controls (Nakatani, 1999). It was found that 12-hydroxyamoorastatone, azedarachin A, trichilin B, and 12-hydroxyamoorastatin displayed a potential antifeedant activity with MIC values of 250, 200, 200, and $150 \mathrm{ppm}$, respectively (Zhou et al., 1996; Nakatani, 1999). At the same time, the most potent antifeedant limonoids were found to be meliacarpinin $\mathrm{A}$, meliacarpinin $\mathrm{C}$, and meliacarpinin $\mathrm{D}$, with a MIC value of
$50 \mathrm{ppm}$ (Nakatani, 1999). In addition, some studies focused on discovering the effective antifeedants against Spodoptera littoralis, another kind of plant pest. As a result, nimbolinin A, nimbolinin $\mathrm{B}$, nimbolinin $\mathrm{C}$, nimbolinin $\mathrm{D}$, trichilinin $\mathrm{D}$, trichilinin $\mathrm{E}, 1-\mathrm{O}$ cinnamoyltrichilinin, 1-deacetylnimbolinin A, spirosendan, and 2-deacetylnimbolinin B exhibited a weak activity at 1,000 ppm (Nakatani et al., 2000). The MIC value of neoazedarachin A, neoazedarachin B, neoazedarachin D, 13-O-acetylazedarachin A, and 1-acetyltrichilin $\mathrm{H}$ against $S$. littoralis was $400 \mathrm{ppm}$, and the MIC value for isotoosendanin, TSN, and azedarachin B was 300 , 200, and 200 ppm, respectively (Nakatani, 1999; Nakatani et al., 2000). Furthermore, 1-cinnamoyl-3-acetyl-11hydroxymeliacarpin was found to possess an attractive insecticidal activity with a $\mathrm{LC}_{50}$ value of $0.48 \mathrm{ppm}$ and a $\mathrm{EC}_{50}$ value of $0.27 \mathrm{ppm}$ (Bohnenstengel et al., 1999). LC-MS guided isolation method was applied to screen promising antifeedant compounds against the fifth-instar larvae of P. rapae, and TSN, isotoosendanin, 12a-hydroxyamoorastatone, mesendanin $\mathrm{H}$, meliatoosenin E, 3-O-acetylohchinolal, salannin, and ohchinal were found to inhibit the feeding ability of $P$. rapae. Among these compounds, mesendanin $\mathrm{H}$ was proven to be the most active limonoid, with an $\mathrm{AFC}_{50}$ value of $0.11 \mathrm{mM}$ (Wang et al., 2020a). The antifeedant activity against Spodoptera exigua of azedarachin A, 12-O-acetylazedarachin A, 12-O-acetylazedarachin B, and 1deoxy-3-tigloyl-11-methoxymeliacarpinin was proven, and the MIC values ranged from 200 to $400 \mathrm{ppm}$ (Huang et al., 1994). For the purpose of finding novel naturally occurring insecticides from plants, Carpinella et al. evaluated the antifeedant and insecticide properties of 12a-hydroxyamoorastatone and azadirachtin against Epilachna paenulata by choice and no-choice assays. In a choice-assay study, 12a-hydroxyamoorastatone and azadirachtin inhibited feeding with $\mathrm{ED}_{50}$ values of 0.80 and $0.72 \mathrm{ug} / \mathrm{cm}^{2}$. These two compounds both possessed a remarkable insecticide activity, which was evidenced by low food intake, weight loss, and even significant mortality $\left(\mathrm{LD}_{50}\right.$ values of 0.76 and $1.24 \mu \mathrm{g} / \mathrm{cm}^{2}$ ) (Carpinella et al., 2003).

\section{Structure-Activity Relationships With Insecticidal Effect}

The structure-activity relationships of limonoids have attracted extensive interest for their remarkable insecticidal activity. It was found that the highly oxidized C-seco limonoids, such as meliacarpinin-type limonoids (meliacarpinin A, meliacarpinin C, and meliacarpinin D), exhibited the most potent antifeedant activity than the less oxidized types of C-seco limonoids, such as nimbolinins (nimbolinin $\mathrm{A}$ and 1-deacetylnimbolinin A-B), ohchinolides (ohchinolide B-C), nimbolidins (nimbolidin B-F), and salannin. Apart from meliacarpinins, the intact trichilin-type limonoids with C-19/C-29 bridged acetals were considered as the higher active compounds, of which 12-hydroxyamoorastatin showed the most potent activity (Nakatani, 1999). In another study, the most active compound against S. eridania was azedarachin A with a 12OH function (Zhou et al., 1996). The insecticidal activity evaluation of three meliacarpins (1,3-dicinnamoyl-11-hydroxymeliacarpin, 1cinnamoyl-3-methacrylyl-11-hydroxymeliacarpin, and 1cinnamoyl-3-acetyl-11-hydroxymeliacarpin) suggested that the property of the ester substituent at C-3 acted a critical role for 
the insecticidal effect. The results showed that 1-cinnamoyl-3-acetyl11-hydroxymeliacarpin that bore a small and relatively hydrophilic acetyl group at C-3 possessed a high activity, while 1,3-dicinnamoyl11-hydroxymeliacarpin with a bulky and more lipophilic cinnamoyl group exhibited the lowest activity (Bohnenstengel et al., 1999) (Figure 11).

\section{Anti-botulinum Effect}

Botulinum neurotoxin (BoNT), the strongest known biotoxin in the world, is a kind of toxin secreted by Clostridium botulinum, which includes seven distinct serotypes (identified as A to G). The nerve endings of a cholinergic neuromuscular junction are considered as its key targets. Botulinum neurotoxin can inhibit the release of acetylcholine through the enzymatic hydrolysis of SNARE protein, which plays a crucial role in neurotransmitter release. Then, the signal transmission of neuromuscular connection was further blocked to paralyze the muscle, which eventually led to the death of animals due to respiratory failure (Rossetto et al., 2014). The fourstep action hypothesis, the proposed mechanism of botulinum toxin on target cells, demonstrated that botulinum toxin binds to receptors on the cell surface firstly and enters the nerve cell through receptormediated internalization. Subsequently, acidification of endocytic vesicles caused the translocation of light chains from the vesicles to the cytoplasm, and the light chains cleave the SNARE protein in the cytosol, thereby completing the last step of the intracellular action of the toxin (Humeau et al., 2000). TSN has been proven to block neuromuscular connection in the phrenic nerve-diaphragm specimens of rats, which was similar to that of BoNT in many aspects-for instance, the dosage-response relationship, the higher temperature coefficient, and the irreversibility of the blocking effect existed in both substances when blocking neuromuscular connections. Nevertheless, there are some differences between TSN and BoNT-for instance, TSN can cause submicroscopic changes of presynaptic motor nerve endings, which refer to the reduced number of synaptic vesicles and the widened synaptic cleft (Xiong, 1985). It was noteworthy that TSN has a facilitation phase before the final inhibition of neurotransmitter release. It means that the quantum release of acetylcholine by TSN is a biphasic regulation of facilitation followed by inhibition (Shi et al., 1982).

Interestingly, TSN, which has similar bioactive properties with BoNT, unexpectedly possesses a prominent anti-botulism effect. Early in the 1980s, TSN was proven to have an obvious therapeutic effect on BoNT-poisoned animals. In the isolated phrenic nerve and diaphragm muscle specimens of mice, both the TSN and BoNT administered simultaneously or TSN administered beforehand showed a significant antagonistic effect on BoNT (Li and Sun, 1983). The anti-botulism effect of TSN exhibited the properties of fast onset and long action time in the isolated neuromuscular specimens and rat models. In addition, TSN has a therapeutic effect on various types of botulism, such as A, B, and $\mathrm{E}$, in mice and rhesus monkeys, which showed broad-spectrum anti-botulism effects (Janda, 2008). Furthermore, in a clinical study, oral administration of TSN can relieve symptoms of botulism, and the patients will recover when treated with the combination of TSN and anti-botulinum serum (Zou et al., 1985). Undoubtedly, structure-activity relationships attracted enough attention in drug research and development. Whether the unusual AB-ring of TSN is related with its anti-botulinum properties was tested. A synthetic strategy allowing access to the AB-fragment of TSN was achieved from a trans-decalin system. However, none of these synthetic structures exhibited antagonism against BoNT/A in the rat spinal cord cellular assay, which demonstrated that complete ABCD nucleus was essential for the anti-BoNT effect of TSN (Nakai et al., 2010).

Recently, the mechanism study revealed that TSN was capable of endowing neuromuscular junctions with a high tolerance to BoNT. Preincubation with TSN for $5 \mathrm{~min}$ can enhance the tolerance to BoNT/A in the isolated phrenic nerve and diaphragm muscle specimens of mice ( $\mathrm{Li}$ and Sun, 1983). In another study, rat phrenic nerve-diaphragm specimens that were preincubated with TSN showed apparent antagonism to botulism, which was manifested as significantly delayed at the time of neuromuscular transmission inhibition. It was found that the anti-BoNT effect of TSN was closely related with the facilitation of neurotransmitter release induced by TSN in a time-dependent manner. In one research, rats injected with TSN (7 mg/kg, i.h.) or blank solvent were sacrificed at different time points (from $15 \mathrm{~min}$ to several days). The results showed that the rat phrenic nerve-diaphragm specimens exhibited high BoNT tolerance after injection with TSN, and the frequency of miniature end-plate potentials was higher than that of the control (Shih and Hsu, 1983).

In the light of the four-step action hypothesis, cleaving of SNARE protein by the light chains was considered as the final process to activate a toxic effect, therefore inhibiting the cleaving procedure emerges as a potential therapeutical strategy. Inspired by this tactic, Zhou et al. explored the anti-BoNT mechanism of TSN by Western blotting. Surprisingly, TSN treatment did not affect the expression of synaptosomal-associated protein of $25 \mathrm{kDa}$ (SNAP-25), syntaxin, and synaptobrevin/vesicleassociated membrane protein in rat cerebral synaptosomes. However, it can completely antagonize the cleavage of SNAP25 induced by BoNT/A. When BoNT acts directly on synaptosomes, TSN can still partially antagonize the cleavage of SNAP-25, but it cannot inhibit the cleavage of SNAP-25 on the synaptosome membrane by light-chain BoNT/A. Thus, the underlying mechanism of TSN against BoNT/A is to block the approach of BoNT to its enzyme substrate (Zhou et al., 2003).

As we know, cleaving of SNARE protein by light chains is a critical event in botulism, and the heavy-chain-formed channel has been confirmed to be indispensable in the translocation of the light chain into the cytosol (Blaustein et al., 1987). To verify the effect of TSN on the channel-forming activity of BoNT/A, the inside-out single-channel recording patch-clamp technique was applied to record the BoNT/A-induced currents in the presence and absence of TSN. The results showed that TSN administration could delay the channel formation and reduce the size of the channels in the PC12 cell membrane, which indicated that TSN could inhibit BoNT/A by interfering with the translocation of BoNT via inhibiting its pore-forming activity (Li and Shi, 2006).

\section{Anti-inflammatory Effect}

Limonoids from genus Melia were considered as an emerging source for discovering potential anti-inflammatory lead compounds. In a representative research, the anti- 
inflammatory effect of TSN was found in dextran sulfate sodiuminduced colitis model. After treatment with TSN, the secretion of proinflammatory cytokines and oxidative stress were blocked, and M1 macrophage polarization and the activation of NLR family pyrin domain containing 3 inflammasome were restrained, accompanied with upregulation of $\mathrm{HO}-1 / \mathrm{Nrf} 2$ expression (Fan et al., 2019). In addition, acetic acid-induced vascular permeability, $\lambda$-carrageenan-induced hind paw edema tests, and acetic acid-induced writhing and hot-plate tests were applied to evaluate the anti-inflammatory effect of limonoids. As a result, two limonoids, iso-toosendanin and 1-O-tigloyl-1$O$-debenzoylohchinal, isolated from the fruit of $M$. toosendan were proven to have anti-inflammatory and analgesic effects (Xie et al., 2008). The NF- $\kappa B$ pathway plays a critical role in inflammation, and one report demonstrated that 1-O-tigloyl-1$O$-deacetyl-nimbolinin B (TNB) possessed the most obvious antiinflammatory effect than the other two limonoids, including nimbolinin $\mathrm{A}$ and nimbolinin $\mathrm{B}$, and the underlying mechanism was through suppressing NF- $\kappa \mathrm{B}$ and JNK activation in microglia cells. In this study, administration with TNB can reduce the production of nitric oxide (NO) and TNF- $\alpha$ in lipopolysaccharide (LPS)-stimulated microglia cells (Tao et al., 2014). In another research, NF- $\kappa B$ luciferase assay was applied to rapidly screen potential NF- $\kappa B$ regulators from the fruits of $M$. toosendan. As a result, seven limonoids were found to inhibit NF$\kappa \mathrm{B}$ activation at the concentration of $10 \mu \mathrm{M}$ (Zhu et al., 2014).

In the LPS-induced mouse macrophage RAW 264.7 cell inflammatory model, five limonoids, including trichilinin B, 3-deacetyl-28-oxosalannolactone, ohchinin, 23hydroxyohchininolide, and 21-hydroxyisoohchininolide, exhibited a significant anti-inflammatory activity by inhibiting the production of $\mathrm{NO}$ with $\mathrm{IC}_{50}$ values from 28.7 to $87.3 \mu \mathrm{M}$. Meanwhile, all these five compounds displayed no or almost no toxicity to the cells (Pan et al., 2014b). Toosendane $\mathrm{B}$ and toosendane $\mathrm{C}$, another two limonoids from the bark of $M$. toosendan, can also obviously reduce NO production in RAW 264.7 cells induced by LPS (Hu et al., 2018). Four NO-inhibited limonoids, including ohchinin, salannin, nimbolinin $\mathrm{D}$, and mesendanin E, were isolated from $M$. azedarach, of which salannin was found to inhibit the expression levels of iNOS and COX-2 proteins in a concentration-dependent manner (Akihisa et al., 2017). In addition, meliazedalides B, a trichilin-class limonoid from the fruits of M. azedarach, also showed a weak anti-inflammatory effect (Qiu et al., 2019). In order to screen anti-neuroinflammatory compounds from $M$. azedarach, a LPS-induced microglia BV-2 cell model was established. Seven compounds, including 1-O-benzoyl-3$O$-deactylnim-bolinin C, 3-deacetyl-12-O-methylvolkensin, 12-O-methyl-1-O-deacetyl-nimbolinin, trichilinin B, 1-Ocinnamoyltrichilinin, 1-acetyltrichilinin, and $12 \alpha-$ hydroxyamoorastatone, were isolated and confirmed as potential inhibitors of $\mathrm{NO}$ production, with $\mathrm{IC}_{50}$ values from 7.73 to $26.75 \mu \mathrm{M}$ (Park et al., 2020).

\section{Antibacterial and Antifungal Effects}

Recently, several limonoids were found to possess a potential antibacterial activity. In the year 2007, 10 limonoids were isolated from the fruits of $M$. toosendan, among which three compounds, including 12-ethoxynimbolinins $\mathrm{C}, 1-\mathrm{O}$-cinnamoyltrichilinin, and trichilinin $\mathrm{B}$, were validated to have an antibacterial activity against oral pathogen Porphyromonas gingivalis, with MIC values of $15.6,31.3$, and $31.5 \mu \mathrm{g} / \mathrm{ml}$, respectively. Nevertheless, they exhibited no obvious bioactivity against Streptococcus mutans. The results indicated that these three limonoids might be specific inhibitors of $P$. gingivalis (Zhang et al., 2007). In 2016, this research group found that $1 \alpha, 7 \alpha-$ ditigloyloxy-3a-acetoxyl-12a-ethoxylnimbolinin and $1 \alpha$ tigloyloxy-3a-acetoxyl-7a-hydroxyl-12 $\beta$-ethoxylnimbolinin, the other two new limonoids, possessed antibacterial activity against $P$. gingivalis, with MIC values of 15.2 and $31.25 \mu \mathrm{g} / \mathrm{ml}$, respectively (Zhang et al., 2016). Unlike previously reported limonoids from fruits or bark, three limonoids were isolated from the seeds of $M$. azedarach, and 7-cinnamoyltoosendanin had significant inhibitory effects against Micrococcus luteus and Bacillus subtilis, with MIC values of 6.25 and $25 \mu \mathrm{g} / \mathrm{ml}$, respectively (Liu et al., 2011). By using a microdilution assay, $\mathrm{Su}$ et al. determined the antibacterial activity of meliarachin D and meliarachin $\mathrm{H}$. The results showed that meliarachin D can inhibit both Staphylococcus aureus $(\mathrm{MIC}=50 \mu \mathrm{g} / \mathrm{ml})$ and $B$. subtilis $(\mathrm{MIC}=50 \mu \mathrm{g} / \mathrm{ml})$; in contrast, meliarachin $\mathrm{H}$ can only suppress the growth of B. subtilis, with a MIC value of $25 \mu \mathrm{g} / \mathrm{ml}$ (Su et al., 2011).

\section{Other Pharmacological Effects}

Apart from the pharmacological effects mentioned above, limonoids also possessed some other bioactivities. In 2018, TSN was reported to exhibit anti-obesity property. By using Oil Red O staining assay, TSN could attenuate lipid accumulation in preadipocytes 3T3-L1. In addition, treatment with TSN can also decreased the mRNA and protein levels of adipocytokines (adiponectin and leptin), CCAAT/enhancer-binding proteins $a$, peroxisome proliferator-activated receptor $\gamma$, fatty acid synthase, and acetyl-CoA carboxylase in adipocytes. Moreover, the weight of gonadal white fat and the serum triacylglycerol content in high-fat-diet-fed mice were reduced by administration with TSN. The underlying mechanism is through activating the $\mathrm{Wnt} / \beta$-catenin pathway (Chen et al., 2018). One study showed that, through altering polymerase acidic protein nuclear localization, TSN could inhibit early influenza A virus infection (Jin YH. et al., 2019). Similarly, hepatitis C virus infection was also inhibited by TSN. It can enhance the effect of alpha interferon ( $\alpha$-IFN), a classical drug in the treatment of $\mathrm{HCV}$ infection, and upregulate the expression of $\alpha$-IFN-related protein (Watanabe et al., 2011). The pharmacological effects are summarized in Table 2.

\section{PHARMACOKINETICS OF LIMONOIDS}

There are few investigations on the pharmacokinetics of limonoids, and only several studies focus on the pharmacokinetics of TSN for elucidating the bioactivity and toxicity mechanism. In 2012, the first UPLC-MS/MS method 


\section{Epoxy-ring at C-14/C-15 VS 15-0xo}

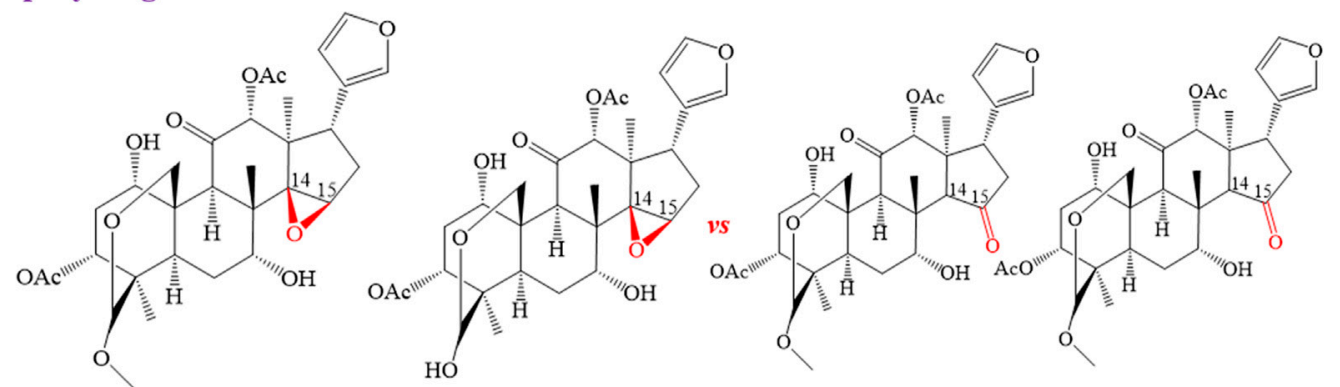

meliarachin $\mathrm{C}$

toosendanin

meliarachin $\mathbf{K}$

meliarachin $\mathbf{G}$

$\begin{array}{ll}\mathrm{HL} 60 \quad \mathrm{IC}_{50}(\mu \mathrm{M}) & 0.65 \\ \mathrm{AZ521} \mathrm{IC}_{50}(\mu \mathrm{M}) & 1.5\end{array}$

C-12 structural modification

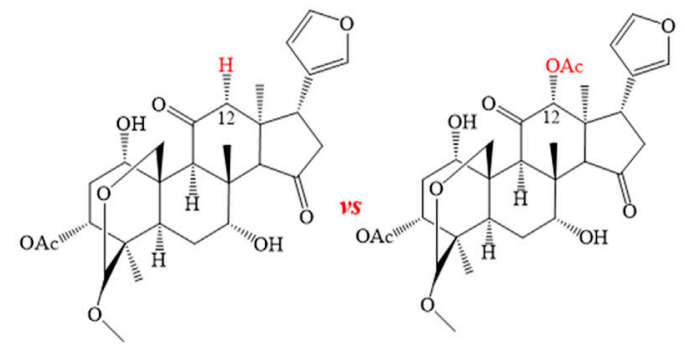

12-dehydroneoazedarachin D

meliarachin $\mathbf{K}$

$\begin{array}{lll}\mathrm{HL} 60 \quad \mathrm{IC}_{50}(\mu \mathrm{M}) & 11.8 & 91.4 \\ \mathrm{AZ} 521 \mathrm{IC}_{50}(\mu \mathrm{M}) & 11.8 & >100\end{array}$

\section{C-3 structural modification}

(n)

1-O-cinnamoyltrichilinin

$\mathrm{HL} 60 \quad \mathrm{IC}_{50}(\mu \mathrm{M}) 5.8$
0.005

0.009
91.4
$>100$
82.0

1.4 100

\section{C-3 structural modification}

trichilinin D

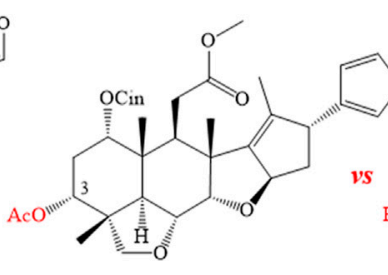

ohchinin acetate

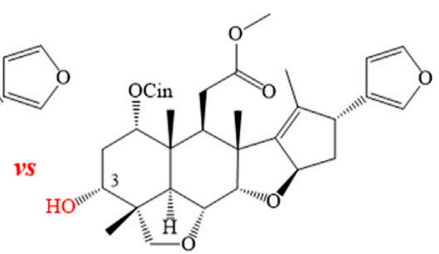

ohchinin

56.3

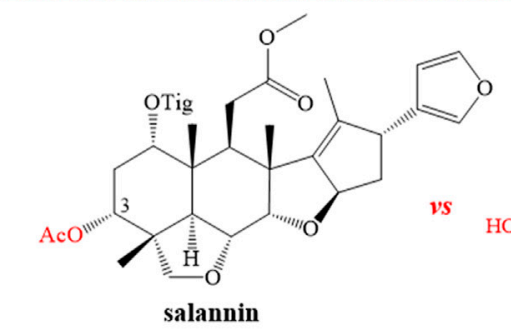

HL60 $\mathrm{IC}_{50}(\mu \mathrm{M}) 67.1$

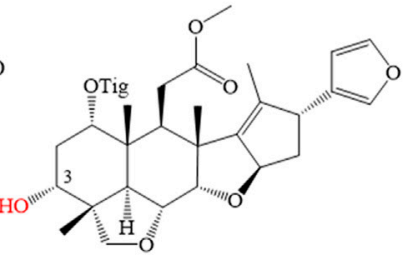

3-O-deacetylsalannin

23.5

FIGURE 10 | The anti-tumor structure-activity relationship of limonoids.

was established for the pharmacokinetic determination of TSN in the rat plasma sample. The results showed that TSN possessed a fast absorption rate with a $T_{\max }(\mathrm{h})$ value of $0.63 \mathrm{~h}$ after oral administration. In terms of $V_{\mathrm{d}}$ level, oral administration $(444,380.3 \pm 204,747.7 \mathrm{ml} / \mathrm{kg})$ had a wider distribution than intravenous administration (32,062.4 $\pm 18,562.8 \mathrm{ml} / \mathrm{kg})$. Moreover, there was a significant variation of clearance between the two types of administration, and the results showed that TSN had a quick elimination rate for oral administration. However, the $C_{\max }$ values of TSN were found 


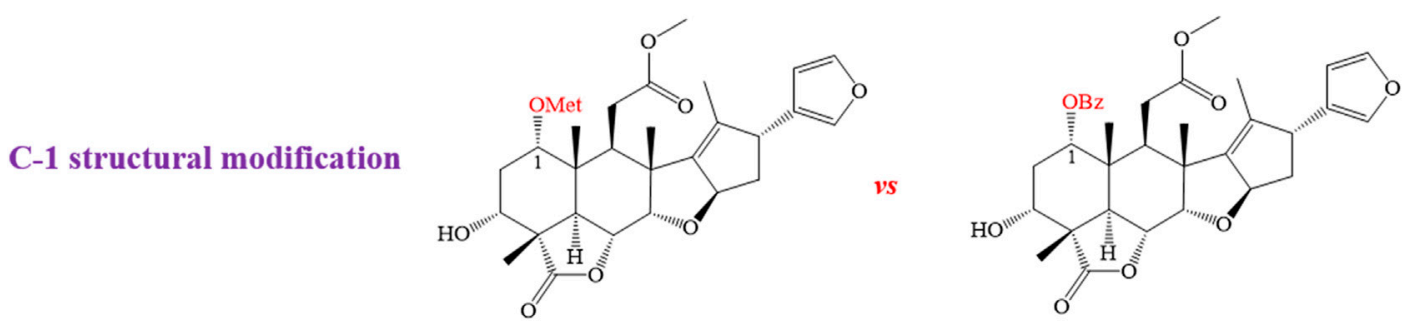

3-deacetyl-4'-demethyl-28-oxosalannin

$\mathrm{HL} 60 \quad \mathrm{IC}_{50}(\mu \mathrm{M})$ 2.8
1-O-decinnamoyl-1-O-benzoyl-28-oxoohchinin 22.7

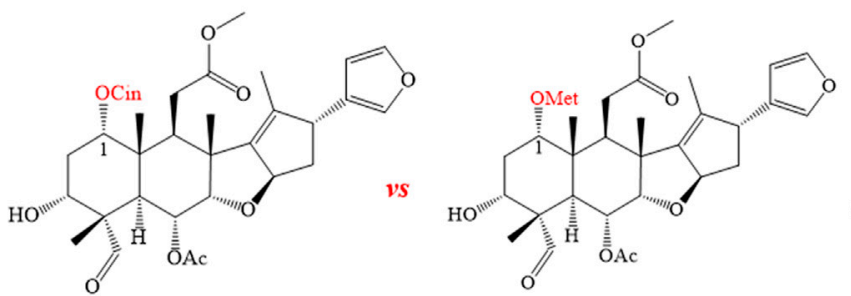

1-cinnamoyl-1-detigloylohchinolal

$\mathrm{HL} 60 \quad \mathrm{IC}_{50}(\mu \mathrm{M})$
8.5 mesendanin $\mathbf{E}$

32.1

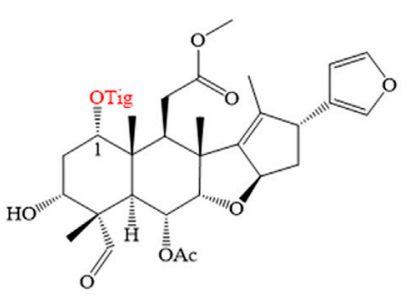

ohchinolal

39.2

FIGURE 10 | (continue) The anti-tumor structure-activity relationship of limonoids.

to be at a low level despite a high oral administration dose of $60 \mathrm{mg} / \mathrm{kg}$ body weight in rat. Furthermore, this study also found a low bioavailability of TSN (9.9\%), which suggested that the bioactivity and toxicity of TSN may be related with its metabolites (Wang et al., 2013). In order to analyze metabolites, the human liver microsomes were incubated with TSN, and these metabolites of TSN were identified by ultra-high performance liquid chromatography-quadrupole-time of flight mass spectrometry. Six metabolites (M1-M6) were tentatively deduced by MS spectra information. Among them, M1, M2, and M3 were produced by oxidation of TSN, and M6 was produced by dehydrogenation of TSN, while M4 and M5 can be obtained by oxidation and dehydrogenation. It is worth noting that the stability of metabolites varied in terms of time, and M1-M5 possessed strong stability, which can last for $120 \mathrm{~min}$. By contrast, M6 reached a maximum value at $20 \mathrm{~min}$ and then decreased gradually. These evidence provide powerful founding for unraveling the metabolic fate of TSN (Wu et al., 2013).

The reactive metabolites, which were formed by the bioactivation of drugs, can partially induce liver injury by causing protein dysfunction and DNA damage (Holt and Ju, 2006). According to reports, several compounds possessed apparent toxicity, which can be ascribed to the bioactivated furan ring (Druckova et al., 2007). Therefore, the TSN that contains a structural alert of the furan ring needs to be explored comprehensively for its metabolites and the bioactivation mechanism. One research showed that esterolysis and conjugation with amino acids were proved as the principal metabolic pathways of TSN. Further experiments found that CYP3A4 could bioactivate the furan ring and produce a cisbutene-1,4-dial intermediate, and the products possibly interacted with peptides or proteins, which might account for the hepatotoxicity caused by TSN. In addition, N-conjugation of the furan ring from diverse amino acids and glutathione (GSH), rather than the widely accepted S-conjugation, acted a key role in the elimination of reactive metabolites of TSN (Yu et al., 2014). Some studies also discussed the potential detoxification mechanism from the aspect of pharmacokinetics. After the combination use of trans-anethole, the $C_{\max }(294.8 \pm 92.01 \mathrm{ng} /$ $\mathrm{L}), \mathrm{AUC}_{(0-\mathrm{t})}(347.2 \pm 128.7 \mathrm{ng} / \mathrm{Lh}), \mathrm{AUC}_{(0-\infty)}(475.6 \pm 210.8 \mathrm{ng} /$ $\mathrm{Lh}), \mathrm{MRT}_{(0-\mathrm{t})}(2.667 \pm 0.989 \mathrm{~h})$, and $\mathrm{MRT}_{(0-\infty)}(5.386 \pm 2.886 \mathrm{~h})$ of TSN were decreased significantly, while the values of $V_{z / F}$ $(8.110 \pm 5.502 \mathrm{~L} / \mathrm{kg})$ were notably increased. These outcomes indicated that co-administration of trans-anethole can decrease the absorption and bioavailability of TSN and shorten the elimination process of TSN, which reduced the risk of toxicity accumulation (Yu et al., 2020).

\section{TOXICITY OF LIMONOIDS}

Although limonoids, especially TSN, possess multiple biological activities, such as anti-tumor effect, insecticidal effect, antibotulinum effect, anti-inflammation effect, etc., a few toxic activities have also been discovered and gradually received attention (Table 3). M. toosendan and M. azedarach were recorded with mild toxicity in Chinese Pharmacopoeia. A large body of evidence found TSN as the main bioactive compound of these two herbs and is also responsible for their toxicity. In vivo and in vitro experiments have proven that hepatotoxicity, pregnancy-toxicity, and embryotoxicity were the primary toxic effects of TSN. In order to verify whether serum miRNAs can be used as potential indicators of hepatotoxicity induced by TSN, miRNA chip analysis was 
Different oxidation degree
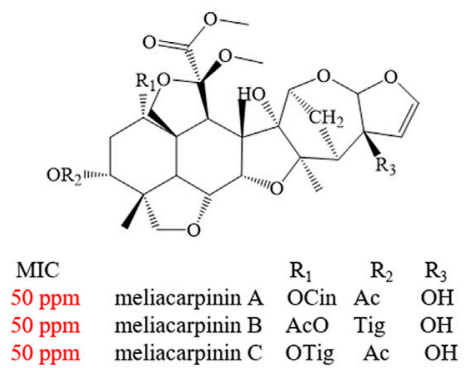

$50 \mathrm{ppm}$ meliacarpinin $\mathrm{C}$ OTig Ac OH

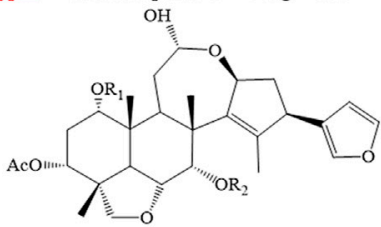

MIC

$1000 \mathrm{ppm}$ nimbolinin A

$1000 \mathrm{ppm}$ 1-deacetylnimbolinin A

1000 ppm 1-deacetylnimbolinin B

\section{$\mathrm{R}_{1} \quad \mathrm{R}_{2}$ \\ $\mathrm{Ac} \mathrm{Bz}$ \\ $\mathrm{H} \quad \mathrm{Bz}$ \\ $\mathrm{H} \quad$ Tig}

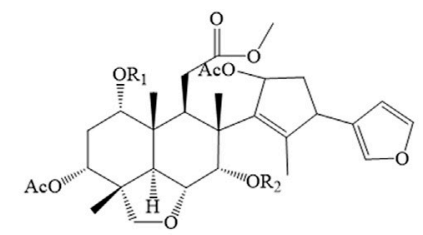

MIC

$500 \mathrm{ppm}$ nimbolidin $\mathrm{B} \quad \begin{aligned} & \mathrm{R}_{1} \\ & \mathrm{Ac}\end{aligned}$

$500 \mathrm{ppm}$ nimbolidin $\mathrm{C} \quad \mathrm{Ac}$

$500 \mathrm{ppm}$ nimbolidin D Tig

$500 \mathrm{ppm}$ nimbolidin E Tig

C-3 structural modification

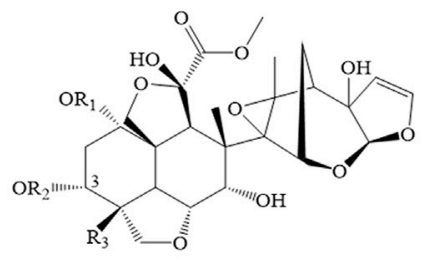

$\mathrm{LC}_{50}$

$2.36 \mathrm{ppm}$ 1,3-dicinnamoyl-11-hydroxymeliacarpin

$1.19 \mathrm{ppm}$ 1-cinnamoyl-3-methacrylyl-11-hydroxymeliacarpin $\mathrm{Cin}$ Met $\mathrm{CH}_{3}$

$0.48 \mathrm{ppm}$ 1-cinnamoyl-3-acetyl-11-hydroxymeliacarpin $\mathrm{Cin}$ Ac $\mathrm{CH}_{3}$

FIGURE 11 | The insecticidal structure-activity relationship of limonoids

applied to detect the target miRNAs in serum. The experiment results showed that administration with TSN $(10 \mathrm{mg} / \mathrm{kg})$ could induce severe liver injury, which manifested as increased alanine aminotransferase/aspartate aminotransferase (ALT/AST) activity and typical pathological changes. Compared to the variation of ALT/AST activity, 22 potential miRNAs can better reflect the characteristics of liver toxicity induced by TSN. According to this research, the increased expression of miRNA-122-3p and mcmvmiRNA-m01-4-3p both existed in the TSN group and other hepatotoxicant groups, including acetaminophen, monocrotaline, and diosbuibin B. Interestingly, increased miRNA-367-3p was only found in the TSN group, which indicated that it could be used as a characteristic biomarker for discovering and discriminating TSN-induced liver injury (Yang et al., 2019).

Aside from investigating the role of miRNA expression alone, Lu et al. integrated the expression of microRNA with mRNA to explore the intricate and dynamic behavior of liver injury induced by TSN. An apparent liver injury was found 9 days after administration with TSN $(80 \mathrm{mg} / \mathrm{kg})$. Unexpectedly, the damage will be restored after 21 days of administration with
TSN (80 mg/kg), which may account for liver regeneration. In addition, there existed dose- and time-specific alterations in global miRNA and mRNA expressions after being exposed to TSN. It can be inferred that the liver injury started with glutathione depletion, accompanied by mitochondrial dysfunction and lipid dysmetabolism, finally leading to hepatocyte necrosis in the liver from functional analyses of the miRNA-mRNA intersection dataset (Lu et al., 2016).

The application of multi-omics strategy, including proteomics and metabolomics, was considered as an advanced approach to explain the toxicity mechanism of TSN. Yan et al. found that triosephosphate isomerase 1 (TPI1) and $\alpha$-enolase (ENOA), two glycolytic enzymes responsible for hepatotoxicity, were covalently modified by reactive metabolites of TSN. In vitro and in vivo experiments indicated that modifications would reduce the activity of TPI1 while inducing the activity of ENOA. Alterations of metabolites were also monitored and analyzed by metabolomics, and the outcomes showed a downward trend in tricarboxylic acid cycle, fatty acid $\beta$-oxidation, and amino acid metabolism, which revealed that the hepatocyte energy metabolism disorder could be induced by TSN (Yan et al., 
2019). In another study, the role of Nrf2/GCL/GSH antioxidant signaling pathway in preventing hepatotoxicity from TSN was elucidated. It was found that TSN can decrease GSH content and Nrf2 expression, increase the expression of the Nrf2 inhibitor protein Kelch-like ECH-associated protein-1, and finally block the antioxidant signaling pathway to induce liver oxidative injury. Quercetin, a natural flavonoid with marked antioxidant ability, was validated to alleviate liver injury caused by TSN, which provided a new insight into compatibility detoxification of drugs (Jin Y. et al., 2019). In addition, fructus foeniculi, a typical detoxification drug for toosendan fructus, was reported to eliminate the toxicity of TSN by decreasing the absorption and bioavailability and accelerating the elimination process (Yu et al., 2020).

Since apoptosis plays an important role in inducing cell death, and TSN can exert its anti-tumor effect through the apoptotic pathway, whether apoptosis also acts as a critical regulator in liver damage caused by TSN needs further exploration. One representative study showed that TSN could inhibit primary rat hepatocyte growth with an $\mathrm{IC}_{50}$ value of $14.94 \mu \mathrm{M}$ for $24 \mathrm{~h}$. The underlying mechanism can be illustrated as TSN caused a decrease of mitochondrial membrane potential and intracellular ATP level and released cytochrome $\mathrm{c}$ to the cytoplasm, ultimately activating caspase- $8,-9$, and -3 to induce cell death. In the meantime, the activation of ROS and MAP kinases was also involved in this process (Zhang et al., 2008).

In recent years, with the increasing adverse effects of plant and vegetable pesticide residues on pregnant female individuals, the reproductive toxicity of TSN was also explored. The first study of reproductive toxicity caused by TSN was conducted by the team of Zhang, and they found that an intraperitoneal injection of TSN $(0.46 \mathrm{mg} / \mathrm{kg})$ could cause specific embryotoxicity to pregnant mice (Zhang X. F. et al., 2005). Later, in another study, the authors found that TSN-induced abortion was related with the imbalance of Th1/Th2 type cytokines, which manifested as increased levels of TNF- $\alpha$ and IFN- $\gamma$ and CD4+/CD8+ ratio. These results partially proved that the immune imbalance is an important event in the reproductive toxicity induced by TSN (Zhang JL. et al., 2010).

The potential toxicity of limonoids has been noticed and emphasized in clinical application. Furthermore, the two herbs were commonly processed prior to clinical use, which can considerably reduce the toxicity. In addition, the compatibility of multiple herbs is another feasible method for toxicity reduction. In fact, countless innovative drugs, including atropine, scopolamine, and anisodamine, from Chinese medicinal herbs are toxic, but they are widely used for clinical purposes after an in-depth study. Therefore, the toxic limonoids (mainly focused on hepatotoxicity) could be candidate drugs via structural modification or targeted drug delivery.

\section{CONCLUSION}

Taken together, the limonoids isolated from genus Melia possess certain similar skeleton structures and can be classified into diverse types, including trichilin class, vilasinin class, havanensin class, azadirone class, nimbolinin class, nimbolidin class, salannin class, ohchinolal class, meliacarpinin class, meliacarpin class, and others. Although enormous attempts have been devoted to synthesize, semisynthesize, and biosynthesize the momentous TSN and other limonoids, no ideal tactic was established for the complicated synthesis process yet. Limonoids, which possess promising bioactivities, such as anti-tumor activity, antifeeding activity, antibotulism effect, anti-inflammatory effect, and antibacterial effect, have obtained global acceptance in agricultural applications and contemporary medicine. In the meantime, the structure-related activity, toxic effects, and pharmacokinetics have also been summarized in this review. Notwithstanding that great breakthroughs have been made in the comprehensive exploration and application of limonoids, some in-depth works are still extremely urgent to be conducted in the future.

Firstly, as a marker of bioactivity and toxicity of $M$. toosendan and $M$. azedarach, TSN has a rigorous criterion for its content limit. Owing to the presence of a hemiacetal structure in the molecular structure, tautomerism will occur, which implies that there are two chromatographic peaks when detecting the content of TSN. In addition, the tautomerism also existed in 1deacetylnimbolinin $\mathrm{B}$, nimbolinin $\mathrm{B}$, nimbolinin $\mathrm{A}$, and 1-Otigloyl-1-O-deacetyl-nimbolinin B (Shen et al., 2014). Even though the content of these compounds can be measured by calculating the sum of the areas of the two peaks, it is important to find another strategy to address this dilemma. Confused by this phenomenon, some researchers tried to utilize acetylation reactions to make $28-\mathrm{OH}$ become a single compound. Nevertheless, this approach was difficult to achieve completely due to the small amount of acetic anhydride and pyridine and was not suitable for extracts of toosendan fructus and meliae cortex (Zhong et al., 1975). Since a tautomer may exert different roles in the treatment of diseases, even the opposite effect, it is therefore crucial to figure out whether there is any difference in bioactivity between the two tautomers.

Secondly, although diverse pharmacological activities of limonoids have been confirmed, their definite molecular targets are still unclear. Given the promising anti-tumor bioactivity against various types of cancers, more studies should be devoted to molecular and cellular mechanism research through the combination of metabolomics and proteomics. To date, there is a large body of research focusing on the pharmacological activities of limonoids by animal or in vitro cell models. However, few clinical trials have been exerted, which restricted its application. We have searched clinical trials of limonoids in "ClinicalTrials.gov" and "trialsearch.who.int", but only one study was conducted to investigate the anti-hypercholesterolemic effect of a limonoid-rich beverage, and no results were posted. We acknowledge that it is a long journey from the discovery of natural bioactive compounds to the development of new drugs. Due to the reported side effect, the potential clinical trials of limonoids were limited. Nevertheless, cautious clinical trials are necessary after reasonable structural modification and toxicity evaluation.

Thirdly, an increasing number of studies reported the toxic effects of limonoids, and TSN has received the most attention. It was reported that hepatotoxicity was considered as the predominant toxicity, which is of great concern worldwide. Nevertheless, few studies focused on the toxicity of other 
TABLE 2 | Pharmacological effects of limonoids.

\begin{tabular}{|c|c|c|c|c|c|}
\hline Compounds & Models & Treatment & $\begin{array}{l}\text { In vitro/ } \\
\text { vivo }\end{array}$ & Effects & Reference \\
\hline Anti-tumor effect & \multicolumn{5}{|c|}{-} \\
\hline Gastric cancer & \multicolumn{5}{|c|}{-} \\
\hline Toosendanin & MKN-45 cells & $60-100 \mathrm{nM}$ & In vitro & Inducing apoptosis & Shao et al. (2020) \\
\hline Toosendanin & AGS cells & $0.5-2 \mu \mathrm{M}$ & In vitro & $\begin{array}{l}\text { Inhibiting cell proliferation and inducing } \\
\text { apoptosis }\end{array}$ & Zhou et al. (2018) \\
\hline Toosendanin & HGC-27 cells & $0.1-0.5 \mu \mathrm{M}$ & In vitro & $\begin{array}{l}\text { Inhibiting cell proliferation and inducing } \\
\text { apoptosis }\end{array}$ & Zhou et al. (2018) \\
\hline Toosendanin & SGC-7901 cells & $0.25-4 \mu \mathrm{M}$ & In vitro & $\begin{array}{l}\text { Inhibiting proliferation, invasion, migration } \\
\text { and inducing apoptosis }\end{array}$ & Wang et al. (2017) \\
\hline Toosendanin & MGC-803 cells & $30-70 \mathrm{nM}$ & In vitro & Inhibiting cell proliferation & Liu et al. (2019) \\
\hline Toosendanin & HGC-27 cells & $0.6 \mu \mathrm{M}$ & In vitro & Inhibiting cell proliferation and invasion & Liu et al. (2019) \\
\hline Trichilinin B & AZ521 cells & $\mathrm{IC}_{50}=58.2 \mu \mathrm{M}$ & In vitro & Cytotoxicity against AZ521 cells & Pan et al. (2014b) \\
\hline $\begin{array}{l}\text { 3-Deacetyl-4'-demethyl-28- } \\
\text { oxosalannin }\end{array}$ & AZ521 cells & $\mathrm{IC}_{50}=3.2 \mu \mathrm{M}$ & In vitro & Inducing apoptosis & Pan et al. (2014b) \\
\hline 23-Hydroxyohchininolide & AZ521 cells & $\mathrm{IC}_{50}=78.5 \mu \mathrm{M}$ & In vitro & Cytotoxicity against AZ521 cells & Pan et al. (2014b) \\
\hline Meliarachin C & AZ521 cells & $\mathrm{IC}_{50}=1.5 \mu \mathrm{M}$ & In vitro & Cytotoxicity against AZ521 cells & $\begin{array}{l}\text { Akihisa et al. } \\
\text { (2013) }\end{array}$ \\
\hline Toosendanin & AZ521 cells & $\mathrm{IC}_{50}=0.009 \mu \mathrm{M}$ & In vitro & Cytotoxicity against AZ521 cells & $\begin{array}{l}\text { Akihisa et al. } \\
\text { (2013) }\end{array}$ \\
\hline 12-Dehydroneoazedarachin D & AZ521 cells & $\mathrm{IC}_{50}=11.8 \mu \mathrm{M}$ & In vitro & Cytotoxicity against AZ521 cells & $\begin{array}{l}\text { Akihisa et al. } \\
\text { (2013) }\end{array}$ \\
\hline Salannin & AZ521 cells & $\mathrm{IC}_{50}=55.4 \mu \mathrm{M}$ & In vitro & Cytotoxicity against AZ521 cells & $\begin{array}{l}\text { Akihisa et al. } \\
\text { (2013) }\end{array}$ \\
\hline $\begin{array}{l}\text { 1-O-Decinnamoyl-1- } \\
\text { O-benzoylohchinin }\end{array}$ & AZ521 cells & $\mathrm{IC}_{50}=82.3 \mu \mathrm{M}$ & In vitro & Cytotoxicity against AZ521 cells & $\begin{array}{l}\text { Akihisa et al. } \\
\text { (2013) }\end{array}$ \\
\hline Ohchininolide & AZ521 cells & $\mathrm{IC}_{50}=82.9 \mu \mathrm{M}$ & In vitro & Cytotoxicity against AZ521 cells & $\begin{array}{l}\text { Akihisa et al. } \\
\text { (2013) }\end{array}$ \\
\hline $\begin{array}{l}\text { 1-O-decinnamoyl-1- } \\
\text { O-benzoylohchininolide }\end{array}$ & AZ521 cells & $\mathrm{IC}_{50}=34.7 \mu \mathrm{M}$ & In vitro & Cytotoxicity against AZ521 cells & $\begin{array}{l}\text { Akihisa et al. } \\
\text { (2013) }\end{array}$ \\
\hline 23-Hydroxyohchininolide & AZ521 cells & $\mathrm{IC}_{50}=78.5 \mu \mathrm{M}$ & In vitro & Cytotoxicity against AZ521 cells & $\begin{array}{l}\text { Akihisa et al. } \\
\text { (2013) }\end{array}$ \\
\hline $\begin{array}{l}\text { 1-O-Decinnamoyl-1-O-benzoyl- } \\
\text { 23-hydroxyohchininolide }\end{array}$ & AZ521 cells & $\mathrm{IC}_{50}=55.7 \mu \mathrm{M}$ & In vitro & Cytotoxicity against AZ521 cells & $\begin{array}{l}\text { Akihisa et al. } \\
(2013)\end{array}$ \\
\hline $\begin{array}{l}\text { 1-O-Decinnamoyl-1-O-benzoyl- } \\
\text { 28-oxoohchinin }\end{array}$ & AZ521 cells & $\mathrm{IC}_{50}=61.7 \mu \mathrm{M}$ & In vitro & Cytotoxicity against AZ521 cells & $\begin{array}{l}\text { Akihisa et al. } \\
\text { (2013) }\end{array}$ \\
\hline Mesendanin E & AZ521 cells & $\mathrm{IC}_{50}=80 \mu \mathrm{M}$ & In vitro & Cytotoxicity against AZ521 cells & $\begin{array}{l}\text { Akihisa et al. } \\
\text { (2013) }\end{array}$ \\
\hline 1-Benzoyl-1-detigloylohchinolal & AZ521 cells & $\mathrm{IC}_{50}=81.6 \mu \mathrm{M}$ & In vitro & Cytotoxicity against AZ521 cells & $\begin{array}{l}\text { Akihisa et al. } \\
(2013)\end{array}$ \\
\hline Nimbolinin D & AZ521 cells & $1 \mathrm{C}_{50}=96.8 \mu \mathrm{M}$ & In vitro & Cytotoxicity against AZ521 cells & $\begin{array}{l}\text { Akihisa et al. } \\
\text { (2013) }\end{array}$ \\
\hline Trichilinin E & SGC-7901 cells & $\mathrm{IC}_{50}=6.9 \mu \mathrm{M}$ & In vitro & Cytotoxicity against SGC-7901 cells & Zhou et al. (2016) \\
\hline \multicolumn{6}{|l|}{ Lung cancer } \\
\hline Toosendanin & $\begin{array}{l}\text { A549 cells, } \\
\text { tumor xenograft } \\
\text { model }\end{array}$ & $50-400 \mathrm{nM}$ & $\begin{array}{l}\text { In vitro } \\
\text { and } \\
\text { in vivo }\end{array}$ & $\begin{array}{l}\text { Enhancing apoptosis and inducing } \\
\text { autophagy }\end{array}$ & Li et al. (2017) \\
\hline Toosendanin & $\begin{array}{l}\text { A549 and A549/ } \\
\text { DDP cells }\end{array}$ & $50 \mu \mathrm{g} / \mathrm{ml}$ & In vitro & $\begin{array}{l}\text { Inducing cell growth inhibition } \\
\text { and enhancing CDDP sensitization }\end{array}$ & Zheng et al. (2018) \\
\hline Toosendanin & $\begin{array}{l}\text { A549 and } \\
\text { H1975 cells }\end{array}$ & $2-10 \mathrm{nM}$ & In vitro & $\begin{array}{l}\text { Inhibiting TGF- } \beta 1 \text {-induced EMT, adhesion, } \\
\text { invasion, and migration }\end{array}$ & Luo et al. (2018) \\
\hline Toosendanin & A549 cells & $20-60 \mu \mathrm{M}$ & In vitro & Inducing apoptosis & \\
\hline 12-Hydroxyamoorastatone & A549 cells & $\mathrm{ED}_{50}=0.92 \mu \mathrm{g} / \mathrm{ml}$ & In vitro & Cytotoxicity against A549 cells & Ahn et al. (1994) \\
\hline 12-Hydroxyamoorastatin & A549 cells & $\mathrm{ED}_{50}=0.04 \mu \mathrm{g} / \mathrm{ml}$ & In vitro & Cytotoxicity against A549 cells & Ahn et al. (1994) \\
\hline 12-Acetoxyamoorastatin & A549 cells & $\mathrm{ED}_{50}=0.01 \mu \mathrm{g} / \mathrm{ml}$ & In vitro & Cytotoxicity against A549 cells & Ahn et al. (1994) \\
\hline 1,12-Diacetyltrichilin B & A549 cells & $\mathrm{IC}_{50}=0.93 \mu \mathrm{M}$ & In vitro & Cytotoxicity against A549 cells & Yuan et al. (2013) \\
\hline Meliarachin C & A549 cells & $\mathrm{IC}_{50}=63.6 \mu \mathrm{M}$ & In vitro & Cytotoxicity against A549 cells & $\begin{array}{l}\text { Akihisa et al. } \\
(2013)\end{array}$ \\
\hline \multirow[t]{2}{*}{$\begin{array}{l}\text { 1-O-Decinnamoyl-1- } \\
\text { O-benzoylohchinin }\end{array}$} & A549 cells & $\mathrm{IC}_{50}=82.3 \mu \mathrm{M}$ & In vitro & Cytotoxicity against A549 cells & $\begin{array}{l}\text { Akihisa et al. } \\
\text { (2013) }\end{array}$ \\
\hline & A549 cells & $\mathrm{IC}_{50}=90.1 \mu \mathrm{M}$ & In vitro & Cytotoxicity against A549 cells & \\
\hline
\end{tabular}


TABLE 2 | (Continued) Pharmacological effects of limonoids.

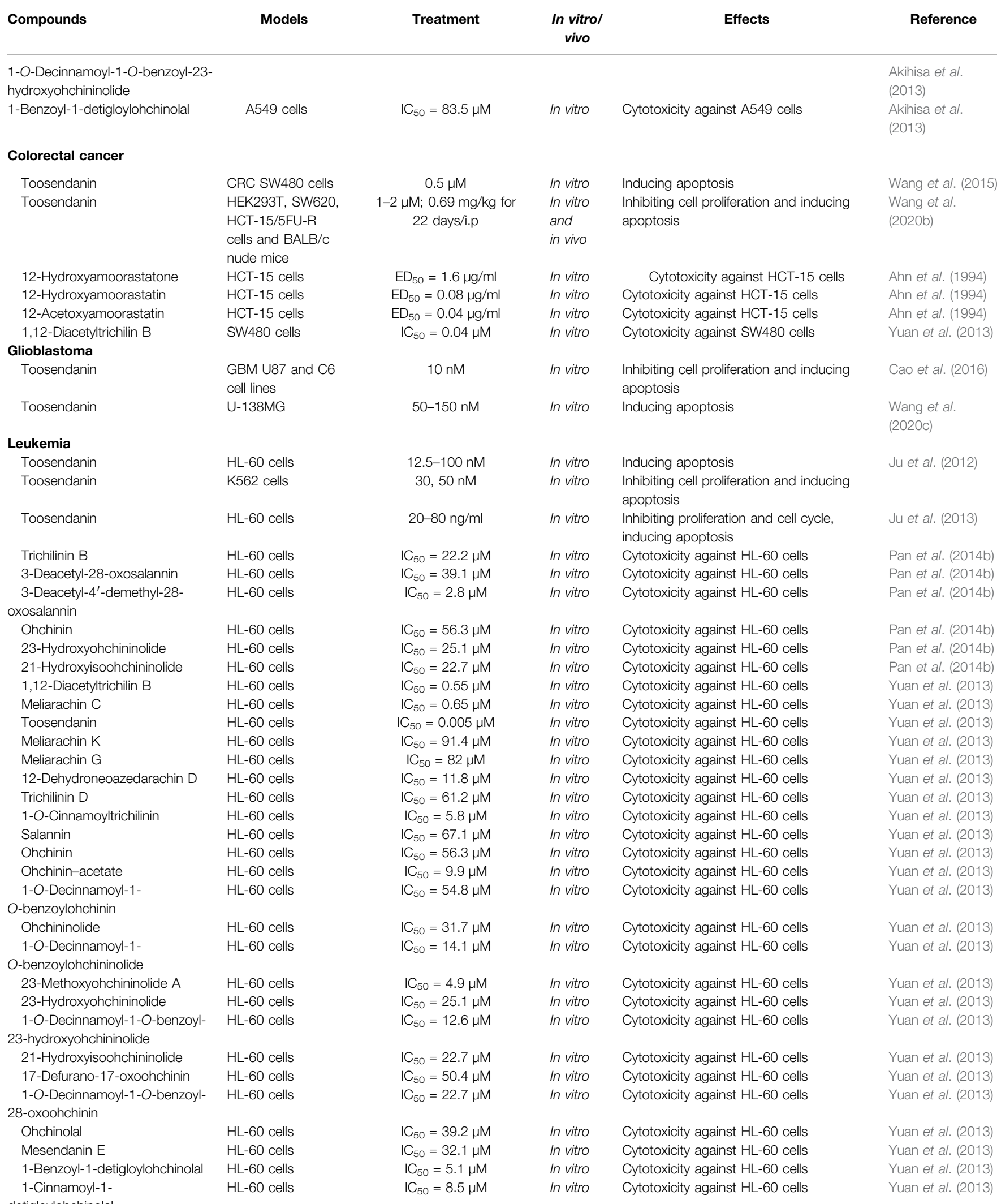


TABLE 2 | (Continued) Pharmacological effects of limonoids.

\begin{tabular}{|c|c|c|c|c|c|}
\hline Compounds & Models & Treatment & $\begin{array}{l}\text { In vitro/ } \\
\text { vivo }\end{array}$ & Effects & Reference \\
\hline Nimbolinin D & HL-60 cells & $\mathrm{IC}_{50}=5.4 \mu \mathrm{M}$ & In vitro & Cytotoxicity against $\mathrm{HL}-60$ cells & Yuan et al. (2013) \\
\hline Toosendanin & $\begin{array}{l}\text { CAVO-3, SKOV-3 } \\
\text { cells }\end{array}$ & $500 \mathrm{nM}$ & In vitro & Inhibiting invasion and migration & Li et al. (2018a) \\
\hline Toosendanin & CAVO-3, ES-2 cells & $500 \mathrm{nM}$ & In vitro & Inducing apoptosis & Li et al. (2019) \\
\hline 12-Hydroxyamoorastatone & SKOV-3 cells & $\mathrm{ED}_{50}=13.7 \mu \mathrm{g} / \mathrm{ml}$ & In vitro & Cytotoxicity against SKOV-3cells & Ahn et al. (1994) \\
\hline 12-Hydroxyamoorastatin & SKOV-3 cells & $\mathrm{ED}_{50}=0.25 \mu \mathrm{g} / \mathrm{ml}$ & In vitro & Cytotoxicity against SKOV-3cells & Ahn et al. (1994) \\
\hline 12-Acetoxyamoorastatin & SKOV-3 cells & $\mathrm{ED}_{50}=0.02 \mu \mathrm{g} / \mathrm{ml}$ & In vitro & Cytotoxicity against SKOV-3cells & Ahn et al. (1994) \\
\hline \multicolumn{6}{|l|}{ Hepatocellular carcinoma } \\
\hline Toosendanin & $\begin{array}{l}\text { SMMC- } 7721 \text { and } \\
\text { Hep3B cells; BALB/ } \\
\text { c mice }\end{array}$ & $\begin{array}{c}\mathrm{IC}_{50}=0.5 \mu \mathrm{M} ; \mathrm{IC} \mathrm{C}_{50}=0.9 \mu \mathrm{M} \\
0.69 \mathrm{mg} / \mathrm{kg} / \text { day for } \\
15 \text { days } / \mathrm{i} . \mathrm{p}\end{array}$ & $\begin{array}{l}\text { In vitro } \\
\text { and } \\
\text { in vivo }\end{array}$ & Inducing apoptosis & He et al. (2010) \\
\hline 12-Ethoxynimbolinins $\mathrm{G}$ & SMMC-7721 cells & $\mathrm{IC}_{50}=27.6 \mu \mathrm{M}$ & In vitro & Cytotoxicity against SMMC-7721 cells & Zhang et al. (2018) \\
\hline 1,12-Diacetyltrichilin B & SMMC-7721 cells & $I C_{50}=0.36 \mu \mathrm{M}$ & In vitro & Cytotoxicity against SMMC-7721 cells & Yuan et al. (2013) \\
\hline Trichilinin E & HepG2 cells & $\mathrm{IC}_{50}=6.9 \mu \mathrm{M}$ & In vitro & Cytotoxicity against HepG2 cells & Zhou et al. (2016) \\
\hline \multicolumn{6}{|l|}{ Breast cancer } \\
\hline Toosendanin & MCF-7/ADM cells & $\begin{array}{l}50 \mathrm{nM} ; 0.69 \mathrm{mg} / \mathrm{kg} / \mathrm{every} \\
2 \text { days for } 15 \text { days/i.p }\end{array}$ & $\begin{array}{l}\text { In vitro } \\
\text { and } \\
\text { in vivo }\end{array}$ & Inducing apoptosis & Wang et al. (2018) \\
\hline Trichilinin B & SK-BR-3 cells & $\mathrm{IC}_{50}=45.1 \mu \mathrm{M}$ & In vitro & Cytotoxicity against SK-BR-3 cells & Pan et al. (2014b) \\
\hline 21-Hydroxyisoohchininolide & SK-BR-3 cells & $\mathrm{IC}_{50}=91.5 \mu \mathrm{M}$ & In vitro & Cytotoxicity against SK-BR-3 cells & Pan et al. (2014b) \\
\hline Toosendansin $\mathrm{H}$ & MCF-7 cells & $6.25 \mu \mathrm{M}$ & In vitro & Cytotoxicity against MCF-7 cells & Li et al. (2020b) \\
\hline Meliatoxin B1 & MCF-7 cells & $6.25 \mu \mathrm{M}$ & In vitro & Cytotoxicity against MCF-7 cells & Li et al. (2020b) \\
\hline 1,12-Diacetyltrichilin B & MCF-7 cells & $\mathrm{IC}_{50}=0.06 \mu \mathrm{M}$ & In vitro & Cytotoxicity against MCF-7 cells & Yuan et al. (2013) \\
\hline $\begin{array}{l}\text { 1-O-Decinnamoyl-1-O-benzoyl- } \\
\text { 23-hydroxyohchininolide }\end{array}$ & MCF-7 cells & $\mathrm{IC}_{50}=4.3 \mu \mathrm{M}$ & In vitro & Cytotoxicity against MCF-7 cells & $\begin{array}{l}\text { Akihisa et al. } \\
\text { (2013) }\end{array}$ \\
\hline 21-Hydroxyisoohchininolide & MCF-7 cells & $\mathrm{IC}_{50}=91.5 \mu \mathrm{M}$ & In vitro & Cytotoxicity against MCF-7 cells & $\begin{array}{l}\text { Akihisa et al. } \\
\text { (2013) }\end{array}$ \\
\hline Ohchinolal & MCF-7 cells & $\mathrm{IC}_{50}=94.4 \mu \mathrm{M}$ & In vitro & Cytotoxicity against MCF-7 cells & $\begin{array}{l}\text { Akihisa et al. } \\
\text { (2013) }\end{array}$ \\
\hline Mesendanin E & MCF-7 cells & $\mathrm{IC}_{50}=70.5 \mu \mathrm{M}$ & In vitro & Cytotoxicity against MCF-7 cells & $\begin{array}{l}\text { Akihisa et al. } \\
\text { (2013) }\end{array}$ \\
\hline 1-Benzoyl-1-detigloylohchinolal & MCF-7 cells & $\mathrm{IC}_{50}=85.0 \mu \mathrm{M}$ & In vitro & Cytotoxicity against MCF-7 cells & $\begin{array}{l}\text { Akihisa et al. } \\
\text { (2013) }\end{array}$ \\
\hline $\begin{array}{l}\text { 1-Cinnamoyl-1- } \\
\text { detigloylohchinolal }\end{array}$ & MCF-7 cells & $\mathrm{IC}_{50}=94.8 \mu \mathrm{M}$ & In vitro & Cytotoxicity against MCF-7 cells & $\begin{array}{l}\text { Akihisa et al. } \\
\text { (2013) }\end{array}$ \\
\hline Nimbolinin D & MCF-7 cells & $\mathrm{IC}_{50}=60.8 \mu \mathrm{M}$ & In vitro & Cytotoxicity against MCF-7 cells & $\begin{array}{l}\text { Akihisa et al. } \\
\text { (2013) }\end{array}$ \\
\hline \multicolumn{6}{|l|}{ Ewing's sarcoma } \\
\hline Toosendanin & SK-ES- 1 cells & $25,50 \mu \mathrm{M}$ & In vitro & Inducing apoptosis & Gao et al. (2019) \\
\hline \multicolumn{6}{|l|}{ Neuroma } \\
\hline Toosendanin & PC12 cells & $0.87 \mu \mathrm{M}$ & In vitro & Inducing apoptosis & Tang et al. (2004) \\
\hline
\end{tabular}


TABLE 2 | (Continued) Pharmacological effects of limonoids.

\begin{tabular}{|c|c|c|c|c|c|}
\hline Compounds & Models & Treatment & $\begin{array}{l}\text { In vitro/ } \\
\text { vivo }\end{array}$ & Effects & Reference \\
\hline Toosendanin & U937 cells & $0.87 \mu \mathrm{M}$ & In vitro & $\begin{array}{l}\text { Suppressing the cell cycle progression and } \\
\text { inducing apoptosis }\end{array}$ & $\begin{array}{l}\text { Zhang et al. } \\
(2005 a)\end{array}$ \\
\hline 12-Deacetyltrichilin I & P388 cells & $\mathrm{IC}_{50}=0.011 \mu \mathrm{g} / \mathrm{ml}$ & In vitro & Cytotoxicity against P388 cells & $\begin{array}{l}\text { Takeya et al. } \\
\text { (1996b) }\end{array}$ \\
\hline 1-Acetyltrichilin $\mathrm{H}$ & P388 cells & $\mathrm{IC}_{50}=0.47 \mu \mathrm{g} / \mathrm{ml}$ & In vitro & Cytotoxicity against P388 cells & $\begin{array}{l}\text { Takeya et al. } \\
\text { (1996b) }\end{array}$ \\
\hline 3-Deacetyltrichilin $\mathrm{H}$ & P388 cells & $\mathrm{IC}_{50}=0.045 \mu \mathrm{g} / \mathrm{ml}$ & In vitro & Cytotoxicity against P388 cells & $\begin{array}{l}\text { Takeya et al. } \\
\text { (1996b) }\end{array}$ \\
\hline 1-Acetyl-3-deacetyltrichilin H & P388 cells & $\mathrm{IC}_{50}=0.4 \mu \mathrm{g} / \mathrm{ml}$ & In vitro & Cytotoxicity against P388 cells & $\begin{array}{l}\text { Takeya et al. } \\
\text { (1996b) }\end{array}$ \\
\hline 1-Acetyl-2-deacetyltrichilin $\mathrm{H}$ & P388 cells & $\mathrm{IC}_{50}=0.66 \mu \mathrm{g} / \mathrm{ml}$ & In vitro & Cytotoxicity against P388 cells & $\begin{array}{l}\text { Takeya et al. } \\
\text { (1996b) }\end{array}$ \\
\hline Meliatoxin B1 & P388 cells & $\mathrm{IC}_{50}=5.4 \mu \mathrm{g} / \mathrm{ml}$ & In vitro & Cytotoxicity against P388 cells & $\begin{array}{l}\text { Takeya et al. } \\
\text { (1996b) }\end{array}$ \\
\hline Trichilin $\mathrm{H}$ & P388 cells & $\mathrm{IC}_{50}=0.16 \mu \mathrm{g} / \mathrm{ml}$ & In vitro & Cytotoxicity against P388 cells & $\begin{array}{l}\text { Takeya et al. } \\
\text { (1996b) }\end{array}$ \\
\hline Trichilin D & P388 cells & $\mathrm{IC}_{50}=0.055 \mu \mathrm{g} / \mathrm{ml}$ & In vitro & Cytotoxicity against P388 cells & $\begin{array}{l}\text { Takeya et al. } \\
\text { (1996b) }\end{array}$ \\
\hline 1,12-Diacetyltrichilin B & P388 cells & $\mathrm{IC}_{50}=0.46 \mu \mathrm{g} / \mathrm{ml}$ & In vitro & Cytotoxicity against P388 cells & $\begin{array}{l}\text { Takeya et al. } \\
\text { (1996b) }\end{array}$ \\
\hline \multicolumn{6}{|l|}{ Pancreatic cancer } \\
\hline Toosendanin & $\begin{array}{l}\text { PANC-1, AsPC-1 } \\
\text { cells; BALB/c mice }\end{array}$ & $\begin{array}{c}200 \mathrm{nM} ; 0.2 \mathrm{mg} / \mathrm{kg} / \text { day for } \\
28 \text { days/i.p }\end{array}$ & $\begin{array}{l}\text { In vitro } \\
\text { and } \\
\text { in vivo }\end{array}$ & $\begin{array}{l}\text { Inhibiting tumorous growth, inhibit } \\
\text { migration and invasion, reversing EMT }\end{array}$ & Pei et al. (2017) \\
\hline \multicolumn{6}{|l|}{ Oral epithelial carcinoma } \\
\hline $\begin{array}{l}\text { Trichilin H } \\
\text { Toosendanin } \\
\text { 12-O-Methylvolkensin }\end{array}$ & $\begin{array}{l}\text { KB cells } \\
\text { KB cells } \\
\text { KB cells }\end{array}$ & $\begin{array}{l}\mathrm{IC}_{50}=0.11 \mu \mathrm{g} / \mathrm{ml} \\
\mathrm{IC}_{50}=3.82 \mu \mathrm{g} / \mathrm{ml} \\
\mathrm{IC}_{50}=8.72 \mu \mathrm{g} / \mathrm{ml}\end{array}$ & $\begin{array}{l}\text { In vitro } \\
\text { In vitro } \\
\text { In vitro }\end{array}$ & $\begin{array}{l}\text { Cytotoxicity against P388 cells } \\
\text { Cytotoxicity against P388 cells } \\
\text { Cytotoxicity against P388 cells }\end{array}$ & $\begin{array}{l}\text { Tada et al. (1999) } \\
\text { Tada et al. (1999) } \\
\text { Tada et al. (1999) }\end{array}$ \\
\hline \multicolumn{6}{|l|}{ Cervical carcinoma } \\
\hline $\begin{array}{l}\text { 15-O-Deacetylnimbolidin B } \\
\text { 12-O-Deacetyltrichilin H } \\
\text { 15-O-Deacetyl-15- } \\
\text { O-methylnimbolidin A }\end{array}$ & $\begin{array}{l}\text { HeLa S3 cells } \\
\text { HeLa S3 cells } \\
\text { HeLa S3 cells }\end{array}$ & $\begin{aligned} I C_{50} & =0.1 \mu \mathrm{M} \\
I C_{50} & =0.48 \mu \mathrm{M} \\
I C_{50} & =37.4 \mu \mathrm{M}\end{aligned}$ & $\begin{array}{l}\text { In vitro } \\
\text { In vitro } \\
\text { In vitro }\end{array}$ & $\begin{array}{l}\text { Cytotoxicity against Hela S3 cells } \\
\text { Cytotoxicity against Hela S3 cells } \\
\text { Cytotoxicity against Hela S3 cells }\end{array}$ & $\begin{array}{l}\text { Zhou et al. (2005) } \\
\text { Zhou et al. (2005) } \\
\text { Zhou et al. (2005) }\end{array}$ \\
\hline $\begin{array}{l}\text { 15-O-Deacetyl-15- } \\
\text { O-methylnimbolidin B }\end{array}$ & HeLa S3 cells & $\mathrm{IC}_{50}=28.3 \mu \mathrm{M}$ & In vitro & Cytotoxicity against Hela S3 cells & Zhou et al. (2005) \\
\hline
\end{tabular}

\section{Melanoma}

12-Hydroxyamoorastatone

12-Hydroxyamoorastatin

12-Acetoxyamoorastatin

\section{SK-MEL-2 cells \\ SK-MEL-2 cells \\ SK-MEL-2 cells}

$\begin{array}{cc}I C_{50}=0.38 \mu \mathrm{g} / \mathrm{ml} & \text { In vitro } \\ I_{50}=0.01 \mu \mathrm{g} / \mathrm{ml} & \text { In vitro } \\ \mathrm{IC}_{50}=0.0007 \mu \mathrm{g} / \mathrm{ml} & \text { In vitro }\end{array}$

Cytotoxicity against SK-MEL-2 cells

Cytotoxicity against SK-MEL-2 cells

Cytotoxicity against SK-MEL-2 cells
Ahn et al. (1994)

Ahn et al. (1994)

Ahn et al. (1994)

Central nervous system tumors

\begin{tabular}{|c|c|c|c|}
\hline 12-Hydroxyamoorastatone & XF498 cells & $\mathrm{IC}_{50}=2 \mu \mathrm{g} / \mathrm{ml}$ & In vitro \\
\hline 12-Hydroxyamoorastatin & XF498 cells & $\mathrm{IC}_{50}=0.02 \mu \mathrm{g} / \mathrm{ml}$ & In vitro \\
\hline 12-Acetoxyamoorastatin & XF498 cells & $\mathrm{IC}_{50}=0.007 \mu \mathrm{g} / \mathrm{ml}$ & In vitro \\
\hline \multicolumn{4}{|c|}{ Antifeeding and insecticide effects } \\
\hline Toosendanin & M. separate & $\mathrm{LC}_{50}=252.23 \mu \mathrm{g} / \mathrm{ml}$ & In vitro \\
\hline Toosendanin & A. aegypti & $\mathrm{LC}_{50}=60.8 \mu \mathrm{g} / \mathrm{ml}$ & In vitro \\
\hline Toosendanin & B. plicatilis & $1.76-2.59 \mathrm{mg} \mathrm{m}^{-3}$ & In vitro \\
\hline Toosendanin & $\begin{array}{l}\text { S. oryzae, C. } \\
\text { ferrugineus }\end{array}$ & $\begin{array}{c}\mathrm{LC}_{50}= \\
\text { respectively }\end{array}$ & In vitro \\
\hline Toosendanin & S. mytilus & $\mathrm{LC}_{50}=6.4 \mu \mathrm{g} / \mathrm{L}$ & In vitro \\
\hline Toosendanin & P. rapae & $100-1,000 \mu \mathrm{g} / \mathrm{ml}$ & In vitro \\
\hline Toosendanin & P. rapae & $3 \mu \mathrm{g} /$ piece & In vitro \\
\hline
\end{tabular}

$\begin{array}{ll}\text { Cytotoxicity against XF498 cells } & \text { Ahn et al. (1994) } \\ \text { Cytotoxicity against XF498 cells } & \text { Ahn et al. (1994) } \\ \text { Cytotoxicity against XF498 cells } & \text { Ahn et al. (1994) }\end{array}$

\section{Antifeeding and insecticide effects}

Causing the destruction of midgut epithelial Li et al. (2020a) cells, leading to the regurgitation, paralysis Disrupting yolk deposition in oocytes, blood Ma et al. (2013) ingestion and digestion, and ovary ecdysteroid production Inhibiting digestive enzymes including Huang et al. (2017) pepsase and tryptase Reducing fecundity and expelling parasite Xie et al. (1995) Reducing the population density and Xu et al. (2019) fecundity Inducing antifeeding 
TABLE 2 | (Continued) Pharmacological effects of limonoids.

Compound

Models

Treatment

In vitro/

Effects

Reference

\begin{tabular}{|c|c|c|c|c|c|}
\hline & & & & acetylase & \\
\hline Toosendanin & P. rapae & 400 ppm & In vitro & Destructing midgut tissue & $\begin{array}{l}\text { Zhang and Zhao } \\
\text { (1991) }\end{array}$ \\
\hline Toosendanin & P. rapae & $2 \mu \mathrm{g} /$ piece & In vitro & $\begin{array}{l}\text { Interfering physiological metabolism and } \\
\text { inhibiting respiratory center }\end{array}$ & $\begin{array}{l}\text { Zhang et al. } \\
\text { (1992b) }\end{array}$ \\
\hline Azedarachin A & S. eridania & $\mathrm{MIC}=200$ ppm & In vitro & Inducing antifeeding & Zhou et al. (1996) \\
\hline Nimbolidin F & S. eridania & $\mathrm{MIC}=500 \mathrm{ppm}$ & In vitro & Inducing antifeeding & Zhou et al. (1997) \\
\hline Ohchinolide C & S. eridania & $\mathrm{MIC}=500$ ppm & In vitro & Inducing antifeeding & Zhou et al. (1997) \\
\hline Salannin & S. eridania & $\mathrm{MIC}=500 \mathrm{ppm}$ & In vitro & Inducing antifeeding & Zhou et al. (1997) \\
\hline Nimbolidin C & S. eridania & $\mathrm{MIC}=500$ ppm & In vitro & Inducing antifeeding & $\begin{array}{l}\text { Nakatani et al. } \\
\text { (1996) }\end{array}$ \\
\hline Nimbolidin D & S. eridania & $\mathrm{MIC}=500$ ppm & In vitro & Inducing antifeeding & $\begin{array}{l}\text { Nakatani et al. } \\
\text { (1996) }\end{array}$ \\
\hline Nimbolidin E & S. eridania & $\mathrm{MIC}=500$ ppm & In vitro & Inducing antifeeding & $\begin{array}{l}\text { Nakatani et al. } \\
\text { (1996) }\end{array}$ \\
\hline Nimbolidin B & S. eridania & $\mathrm{MIC}=500$ ppm & In vitro & Inducing antifeeding & $\begin{array}{l}\text { Nakatani et al. } \\
\text { (1996) }\end{array}$ \\
\hline Toosendanin & S. littoralis & $\mathrm{MIC}=200$ ppm & In vitro & Inducing antifeeding & $\begin{array}{l}\text { Nakatani et al. } \\
(2000)\end{array}$ \\
\hline Nimbolinin A & S. littoralis & $\mathrm{MIC}=1,000 \mathrm{ppm}$ & In vitro & Inducing antifeeding & $\begin{array}{l}\text { Nakatani et al. } \\
\text { (2000) }\end{array}$ \\
\hline Nimbolinin C & S. littoralis & $\mathrm{MIC}=1,000 \mathrm{ppm}$ & In vitro & Inducing antifeeding & $\begin{array}{l}\text { Nakatani et al. } \\
\text { (2000) }\end{array}$ \\
\hline Nimbolinin D & S. littoralis & $\mathrm{MIC}=1,000 \mathrm{ppm}$ & In vitro & Inducing antifeeding & $\begin{array}{l}\text { Nakatani et al. } \\
\text { (2000) }\end{array}$ \\
\hline Nimbolinin B & S. littoralis & $\mathrm{MIC}=1,000 \mathrm{ppm}$ & In vitro & Inducing antifeeding & $\begin{array}{l}\text { Nakatani et al. } \\
\text { (2000) }\end{array}$ \\
\hline Trichilinin D & S. littoralis & $\mathrm{MIC}=1,000 \mathrm{ppm}$ & In vitro & Inducing antifeeding & $\begin{array}{l}\text { Nakatani et al. } \\
\text { (2000) }\end{array}$ \\
\hline Trichilinin E & S. littoralis & $\mathrm{MIC}=1,000 \mathrm{ppm}$ & In vitro & Inducing antifeeding & $\begin{array}{l}\text { Nakatani et al. } \\
\text { (2000) }\end{array}$ \\
\hline 1-O-Cinnamoyltrichilinin & S. littoralis & $\mathrm{MIC}=1,000 \mathrm{ppm}$ & In vitro & Inducing antifeeding & $\begin{array}{l}\text { Nakatani et al. } \\
\text { (2000) }\end{array}$ \\
\hline $\begin{array}{l}\text { 1-Deoxy-3-tigloyl-11- } \\
\text { methoxymeliacarpinin }\end{array}$ & S. exigua & $3 \mu \mathrm{g} / \mathrm{cm}^{2}$ & In vitro & Inducing antifeeding & $\begin{array}{l}\text { Nakatani et al. } \\
\text { (1993) }\end{array}$ \\
\hline Trichilinin B & S. eridania & $\mathrm{MIC}=1,000 \mathrm{ppm}$ & In vitro & Inducing antifeeding & Nakatani (1999) \\
\hline Trichilinin C & S. eridania & $\mathrm{MIC}=1,000 \mathrm{ppm}$ & In vitro & Inducing antifeeding & Nakatani (1999) \\
\hline 12-Hydroxyamoorastatin & S. eridania & $\mathrm{MIC}=150$ ppm & In vitro & Inducing antifeeding & Nakatani (1999) \\
\hline Toosendanin & S. eridania & $\mathrm{MIC}=300$ ppm & In vitro & Inducing antifeeding & Nakatani (1999) \\
\hline 12-O-Acetylazedarachin A & S. eridania & $\mathrm{MIC}=400 \mathrm{ppm}$ & In vitro & Inducing antifeeding & Nakatani (1999) \\
\hline 13-O-Acetylazedarachin A & S. littoralis & $\mathrm{MIC}=400$ ppm & In vitro & Inducing antifeeding & Nakatani (1999) \\
\hline Azedarachin B & S. littoralis & $\mathrm{MIC}=200$ ppm & In vitro & Inducing antifeeding & Nakatani (1999) \\
\hline 12-O-Acetylazedarachin B & S. eridania & $\mathrm{MIC}=400$ ppm & In vitro & Inducing antifeeding & Nakatani (1999) \\
\hline Trichilin B & S. eridania & $\mathrm{MIC}=200$ ppm & In vitro & Inducing antifeeding & Nakatani (1999) \\
\hline Trichilin $\mathrm{H}$ & S. eridania & $\mathrm{MIC}=400 \mathrm{ppm}$ & In vitro & Inducing antifeeding & Nakatani (1999) \\
\hline Trichilin I & S. eridania & $\mathrm{MIC}=400$ ppm & In vitro & Inducing antifeeding & Nakatani (1999) \\
\hline Trichilin J & S. eridania & $\mathrm{MIC}=400 \mathrm{ppm}$ & In vitro & Inducing antifeeding & Nakatani (1999) \\
\hline Trichilin K & S. eridania & $\mathrm{MIC}=400 \mathrm{ppm}$ & In vitro & Inducing antifeeding & Nakatani (1999) \\
\hline Trichilin L & S. eridania & $\mathrm{MIC}=400 \mathrm{ppm}$ & In vitro & Inducing antifeeding & Nakatani (1999) \\
\hline 1-Acetyltrichilin $\mathrm{H}$ & S. littoralis & $\mathrm{MIC}=400$ ppm & In vitro & Inducing antifeeding & Nakatani (1999) \\
\hline 12-Hydroxyamoorastatone & S. eridania & $\mathrm{MIC}=250$ ppm & In vitro & Inducing antifeeding & Nakatani (1999) \\
\hline Isotoosendanin & S. littoralis & $\mathrm{MIC}=300$ ppm & In vitro & Inducing antifeeding & Nakatani (1999) \\
\hline Neoazedarachin A & S. littoralis & $\mathrm{MIC}=400$ ppm & In vitro & Inducing antifeeding & Nakatani (1999) \\
\hline Neoazedarachin B & S. littoralis & $\mathrm{MIC}=400$ ppm & In vitro & Inducing antifeeding & Nakatani (1999) \\
\hline Neoazedarachin D & S. littoralis & $\mathrm{MIC}=400$ ppm & In vitro & Inducing antifeeding & Nakatani (1999) \\
\hline 1-Deacetylnimbolinin A & S. littoralis & $\mathrm{MIC}=1,000 \mathrm{ppm}$ & In vitro & Inducing antifeeding & Nakatani (1999) \\
\hline 2-DeacetyInimbolinin B & S. littoralis & $\mathrm{MIC}=1,000 \mathrm{ppm}$ & In vitro & Inducing antifeeding & Nakatani (1999) \\
\hline Ohchinolide B & S. eridania & $\mathrm{MIC}=1,000 \mathrm{ppm}$ & In vitro & Inducing antifeeding & Nakatani (1999) \\
\hline Ohchinolide C & S. eridania & $\mathrm{MIC}=1,000 \mathrm{ppm}$ & In vitro & Inducing antifeeding & Nakatani (1999) \\
\hline 3-O-Acetylohchinolal & S. eridania & $\mathrm{MIC}=1,000 \mathrm{ppm}$ & In vitro & Inducing antifeeding & Nakatani (1999) \\
\hline Meliacarpinin A & S. eridania & $\mathrm{MIC}=50 \mathrm{ppm}$ & In vitro & Inducing antifeeding & $\begin{array}{l}\text { Nakatani (1999) } \\
\text { on following page) }\end{array}$ \\
\hline
\end{tabular}

Reducing activity of microsomal multifunctional oxidase, protease, intestinal acetylase 
TABLE 2 | (Continued) Pharmacological effects of limonoids.

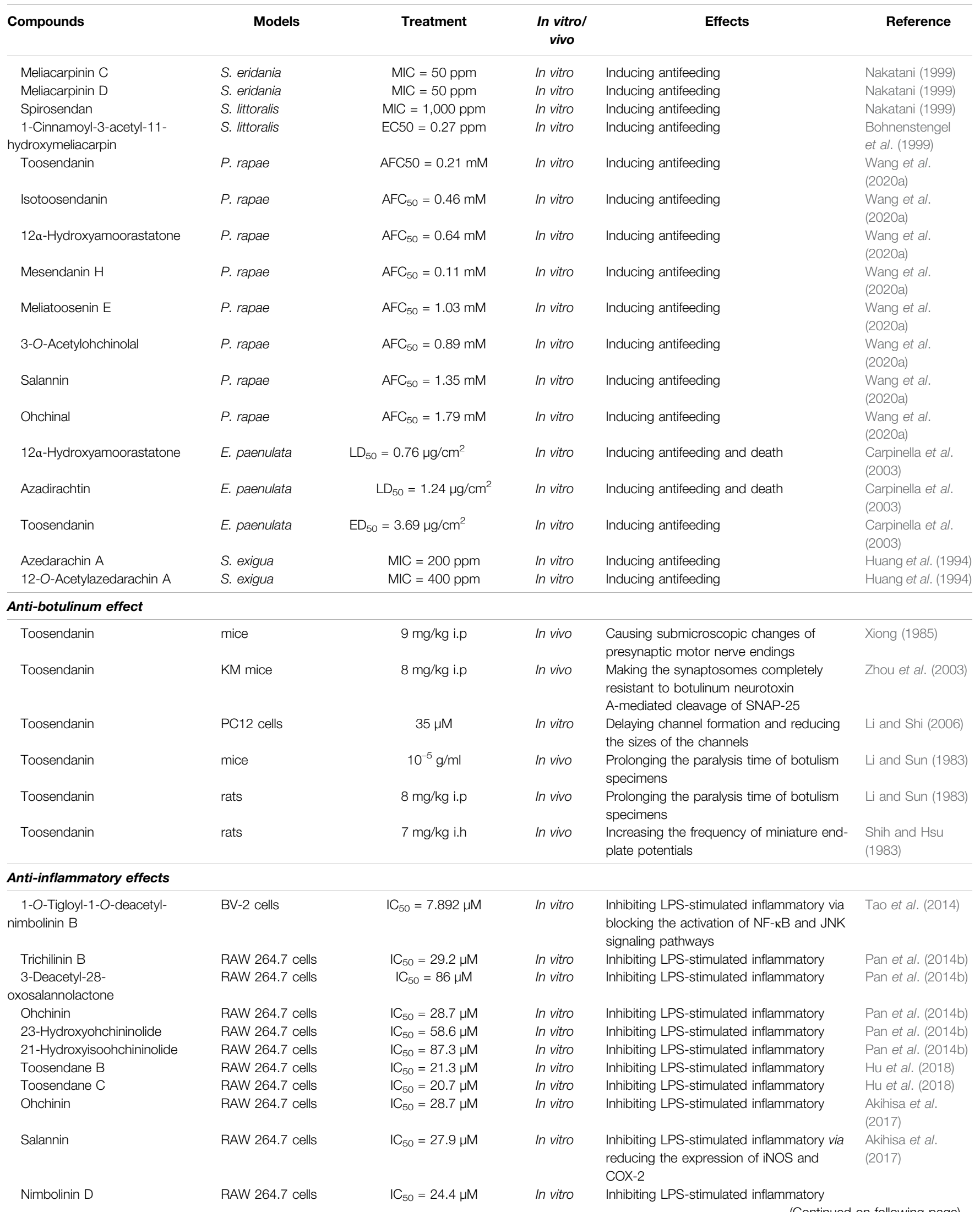


TABLE 2 | (Continued) Pharmacological effects of limonoids.

\begin{tabular}{|c|c|c|c|c|c|}
\hline Compounds & Models & Treatment & $\begin{array}{l}\text { In vitro/ } \\
\text { vivo }\end{array}$ & Effects & Reference \\
\hline & & & & & $\begin{array}{l}\text { Akihisa et al. } \\
\text { (2017) }\end{array}$ \\
\hline Mesendanin E & RAW 264.7 cells & $\mathrm{IC}_{50}=23.8 \mu \mathrm{M}$ & In vitro & Inhibiting LPS-stimulated inflammatory & $\begin{array}{l}\text { Akihisa et al. } \\
\text { (2017) }\end{array}$ \\
\hline 12-Ethoxynimbolinin A & HepG2 cells & $10 \mu \mathrm{M}$ & In vitro & Suppressing NF-kB activation & Zhu et al. (2014) \\
\hline Nimbolinin C & HepG2 cells & $10 \mu \mathrm{M}$ & In vitro & Suppressing NF-kB activation & Zhu et al. (2014) \\
\hline 1-O-Tigloyl-1- & HepG2 cells & $10 \mu \mathrm{M}$ & In vitro & Suppressing NF-кB activation & Zhu et al. (2014) \\
\hline \multicolumn{6}{|l|}{ O-debenzoylohchinal } \\
\hline 1-Acetyltrichilinin & HepG2 cells & $10 \mu \mathrm{M}$ & In vitro & Suppressing NF-kB activation & Zhu et al. (2014) \\
\hline Trichilinin B & HepG2 cells & $10 \mu \mathrm{M}$ & In vitro & Suppressing NF-kB activation & Zhu et al. (2014) \\
\hline 1-O-Cinnamoyltrichilinin & HepG2 cells & $10 \mu \mathrm{M}$ & In vitro & Suppressing NF-кB activation & Zhu et al. (2014) \\
\hline Trichilinin D & HepG2 cells & $10 \mu \mathrm{M}$ & In vitro & Suppressing NF-kB activation & Zhu et al. (2014) \\
\hline Isotoosendanin & Mice & $100 \mathrm{mg} / \mathrm{kg}$ & In vivo & $\begin{array}{l}\text { Inhibiting acetic acid-induced vascular } \\
\text { permeability and } \lambda \text {-carrageenan induced } \\
\text { hind paw edema }\end{array}$ & Xie et al. (2008) \\
\hline $\begin{array}{l}\text { 1-O-Tigloyl-1- } \\
\text { O-debenzoylohchinal }\end{array}$ & Mice & $100 \mathrm{mg} / \mathrm{kg}$ & In vivo & $\begin{array}{l}\text { Inhibiting acetic acid-induced vascular } \\
\text { permeability and } \lambda \text {-carrageenan induced } \\
\text { hind paw edema }\end{array}$ & Xie et al. (2008) \\
\hline Meliazedalides B & RAW 264.7 & $37.41 \mu \mathrm{M}$ & In vitro & Inhibiting LPS-stimulated inflammatory & Qiu et al. (2019) \\
\hline $\begin{array}{l}\text { 1-O-benzoyl-3-O-deactylnim- } \\
\text { bolinin C }\end{array}$ & BV-2 cells & $21.95 \mu \mathrm{M}$ & In vitro & Inhibiting LPS-stimulated inflammatory & Park et al. (2020) \\
\hline $\begin{array}{l}\text { 3-Deacetyl-12- } \\
\text { O-methylvolkensin }\end{array}$ & BV-2 cells & $21.37 \mu \mathrm{M}$ & In vitro & Inhibiting LPS-stimulated inflammatory & Park et al. (2020) \\
\hline $\begin{array}{l}\text { 12-O-Methyl-1-O-deacetyl- } \\
\text { nimbolinin }\end{array}$ & BV-2 cells & $23.16 \mu \mathrm{M}$ & In vitro & Inhibiting LPS-stimulated inflammatory & Park et al. (2020) \\
\hline Trichilinin B & BV-2 cells & $15.28 \mu \mathrm{M}$ & In vitro & Inhibiting LPS-stimulated inflammatory & Park et al. (2020) \\
\hline 1-O-Cinnamoyltrichilinin & BV-2 cells & $7.73 \mu \mathrm{M}$ & In vitro & Inhibiting LPS-stimulated inflammatory & Park et al. (2020) \\
\hline 1-Acetyltrichilinin & BV-2 cells & $20.61 \mu \mathrm{M}$ & In vitro & Inhibiting LPS-stimulated inflammatory & Park et al. (2020) \\
\hline $12 \alpha$-Hydroxyamoorastatone & BV-2 cells & $26.75 \mu \mathrm{M}$ & In vitro & Inhibiting LPS-stimulated inflammatory & Park et al. (2020) \\
\hline Toosendanin & Mice & $0.5,1.0 \mathrm{mg} / \mathrm{kg}$ i.p. for 7 days & In vivo & $\begin{array}{l}\text { Alleviating DSS-induced colitis via inhibiting } \\
\text { M1 macrophage polarization and regulating } \\
\text { NLRP3 inflammasome and Nrf2/HO-1 } \\
\text { signaling }\end{array}$ & Fan et al. (2019) \\
\hline
\end{tabular}

Antibacterial and antifungal effects

\begin{tabular}{|c|c|}
\hline $1 \alpha, 7 \alpha$-Ditigloyloxy-3 $\alpha$-acetoxyl- & P. gingivalis \\
\hline $12 \alpha$-ethoxylnimbolinin & \\
\hline 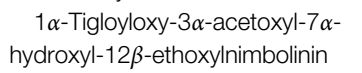 & P. gingivalis \\
\hline 12-Ethoxynimbolinins C & P. gingivalis \\
\hline 1-O-Cinnamoyltrichilinin & P. gingivalis \\
\hline Trichilinin B & P. gingivalis \\
\hline 7-Cinnamoyltoosendanin & M. luteus \\
\hline 7-Cinnamoyltoosendanin & B. subtilis \\
\hline Meliarachin D & S. aureus \\
\hline Meliarachin D & B. subtilis \\
\hline Meliarachin H & B. subtilis \\
\hline
\end{tabular}

\begin{tabular}{|c|c|}
\hline $\mathrm{MIC}=15.2 \mu \mathrm{g} / \mathrm{ml}$ & In vitro \\
\hline $\mathrm{MIC}=31.25 \mu \mathrm{g} / \mathrm{ml}$ & In vitro \\
\hline $\mathrm{MIC}=15.6 \mu \mathrm{g} / \mathrm{ml}$ & In vitro \\
\hline $\mathrm{MIC}=31.3 \mu \mathrm{g} / \mathrm{ml}$ & In vitro \\
\hline $\mathrm{MIC}=31.5 \mu \mathrm{g} / \mathrm{ml}$ & In vitro \\
\hline $\mathrm{MIC}=6.25 \mu \mathrm{g} / \mathrm{ml}$ & In vitro \\
\hline $\mathrm{MIC}=25 \mu \mathrm{g} / \mathrm{ml}$ & In vitro \\
\hline $\mathrm{MIC}=50 \mu \mathrm{g} / \mathrm{ml}$ & In vitro \\
\hline $\mathrm{MIC}=50 \mu \mathrm{g} / \mathrm{ml}$ & In vitro \\
\hline $\mathrm{MIC}=25 \mu \mathrm{g} / \mathrm{ml}$ & In vitro \\
\hline
\end{tabular}

Inhibitory effects against $P$. gingivalis

Zhang et al. (2016)

Inhibitory effects against $P$. gingivalis

Zhang et al. (2016)

Inhibitory effects against $P$. gingivalis Inhibitory effects against $P$. gingivalis Inhibitory effects against $P$. gingivalis

Zhang et al. (2007) Zhang et al. (2007) Zhang et al. (2007) Inhibitory effects against $M$. luteus Inhibitory effects against $B$. subtilis Liu et al. (2011) Liu et al. (2011) Inhibitory effects against $S$. aureus Inhibitory effects against $B$. subtilis Su et al. (2011) Su et al. (2011) Su et al. (2011)

limonoids that have a skeleton structure similar to that of TSN. Previous reports showed that the content of 1-deacetylnimbolinin $\mathrm{B}$ was higher than TSN in fructus toosendan, and the contents of nimbolinin $\mathrm{B}$, nimbolinin $\mathrm{A}$, and 1-O-tigloyl-1-O-deacetylnimbolinin B exhibited no noticeable difference with TSN (Shen et al., 2014). Thus, it is indispensable to carry out extensive toxicity screening of other limonoids for the comprehensive quality control of fructus toosendan and meliae cortex. Moreover, the lack of a clear toxicity mechanism seriously restricts its clinical application. Hence, the toxic molecular target and the metabolism changes in vivo, accompanied with potential detoxification and/or a toxicity enhancement metabolism pathway, need to be further explored. Interestingly, processing can reduce the toxicity of fructus toosendan, which suggests that heating, acidification, and other physical processes may transform toxic limonoids into less toxic compounds. Although the synthesis of toosendanin is challenging yet, a breakthrough has been made in the synthesis of azadirachtin (one limonoid of genus Azadirachta), which points out the direction of future study. The successful total synthesis was achieved by the strategy 
TABLE 3 | Toxicities and side effects of limonoids.

\begin{tabular}{|c|c|c|c|c|c|}
\hline Compounds & Toxic type & Model & $\begin{array}{l}\text { LD }_{50} / \text { toxic dose } \\
\text { range }\end{array}$ & Toxic reactions & Reference \\
\hline Toosendanin & $\begin{array}{l}\text { Pregnancy } \\
\text { toxicity }\end{array}$ & Mice & $\begin{array}{l}0.2-0.8 \mathrm{mg} / \mathrm{kg} \text { (i.p. for } \\
7 \text { days) }\end{array}$ & Increasing the level of IFN- $\gamma, \mathrm{TNF}-\alpha, \mathrm{CD}^{+}$, and $\mathrm{CD} 8^{+}$T lymphocytes & $\begin{array}{l}\text { Zhang et al. } \\
\text { (2010a) }\end{array}$ \\
\hline Toosendanin & Hepatotoxicity & Mice & $\begin{array}{l}10 \mathrm{mg} / \mathrm{kg} \text { (i.p. for } 6 \text {, } \\
12,24 \mathrm{~h})\end{array}$ & $\begin{array}{l}\text { Increasing the level of serum ALT and AST and decreasing the } \\
\text { expression of mir-367-3p }\end{array}$ & $\begin{array}{l}\text { Yang et al. } \\
\text { (2019) }\end{array}$ \\
\hline Toosendanin & Hepatotoxicity & Mice & $\begin{array}{l}80 \mathrm{mg} / \mathrm{kg} \text { (i.p. for } 9 \\
\text { days) }\end{array}$ & $\begin{array}{l}\text { Decreasing the body weight, increasing the level of serum ALT and } \\
\text { AST, and enhancing the expression of Fmo3 }\end{array}$ & Lu et al. (2016) \\
\hline Toosendanin & Hepatotoxicity & Mice & $\begin{array}{l}3.75-15 \mathrm{mg} / \mathrm{kg} \text { (i.p. } \\
\quad \text { for } 24 \mathrm{~h})\end{array}$ & $\begin{array}{l}\text { Decreasing the body weight, increasing the level of serum ALT and } \\
\text { AST, and inducing energy metabolism disorder and hepatic steatosis }\end{array}$ & Yan et al. (2019) \\
\hline Toosendanin & Hepatotoxicity & $\begin{array}{l}\text { Primary } \\
\text { hepatocyte cells }\end{array}$ & $\mathrm{IC}_{50}=30.65 \mu \mathrm{M}$ & $\begin{array}{l}\text { Promoting } \mathrm{Na}^{+} \text {influx and } \mathrm{K}^{+} \text {efflux, decreasing the size of the cell } \\
\text { membrane, and increasing the cell membrane permeability }\end{array}$ & Yan et al. (2019) \\
\hline Toosendanin & Hepatotoxicity & Mice & $\begin{array}{l}10 \mathrm{mg} / \mathrm{kg} \text { (i.p. for } 6 \text {, } \\
12,24 \mathrm{~h})\end{array}$ & $\begin{array}{l}\text { Increasing the level of serum ALT, AST, ALP, TBIL, ROS, and MDA } \\
\text { and decreasing GSH content and Nrf2 expression }\end{array}$ & Jin et al. (2019b) \\
\hline Toosendanin & Hepatotoxicity & L-02 cells & $2-10 \mu \mathrm{M}$ & $\begin{array}{l}\text { Reducing GCL activity, GSH content, and expression of GCLC/ } \\
\text { GCLM and Nrf2; increasing ROS and Keap1 expression }\end{array}$ & Jinet al. (2019b) \\
\hline Toosendanin & Hepatotoxicity & $\begin{array}{l}\text { Primary } \\
\text { hepatocyte cells }\end{array}$ & $\mathrm{IC}_{50}=14.94 \mu \mathrm{M}$ & Inducing mitochondrial dysfunction and caspase activation & $\begin{array}{l}\text { Zhang et al. } \\
(2008)\end{array}$ \\
\hline Toosendanin & Embryotoxicity & Mice & $\begin{array}{l}0.46 \mathrm{mg} / \mathrm{kg} \text { (i.p. for } 3 \\
\text { days) }\end{array}$ & Inducing abortion & $\begin{array}{l}\text { Zhang et al. } \\
(2005 b)\end{array}$ \\
\hline
\end{tabular}

called "relay route" or "relay synthesis", which attempted to degrade azadirachtin to a specific potential synthetic intermediate and then transform this back into the natural product. Therefore, a similar strategy is expected to be applied in the synthesis of toosendanin.

\section{AUTHOR CONTRIBUTIONS}

WF contributed to writing-original draft. LF contributed to resources. ZW contributed to conceptualization and supervision.

\section{REFERENCES}

Ahn, J.-W., Choi, S.-U., and Lee, C.-O. (1994). Cytotoxic Limonoids from Melia Azedarach Var. Japonica. Phytochemistry 36, 1493-1496. doi:10.1016/s00319422(00)89749-6

Akihisa, T., Nishimoto, Y., Ogihara, E., Matsumoto, M., Zhang, J., and Abe, M. (2017). Nitric Oxide Production-Inhibitory Activity of Limonoids from Azadirachta indica and Melia Azedarach. Chem. Biodivers. 14. doi:10.1002/ cbdv.201600468

Akihisa, T., Pan, X., Nakamura, Y., Kikuchi, T., Takahashi, N., Matsumoto, M., et al. (2013). Limonoids from the Fruits of Melia Azedarach and Their Cytotoxic Activities. Phytochemistry 89, 59-70. doi:10.1016/ j.phytochem.2013.01.015

Ashkenazi, A., Pai, R. C., Fong, S., Leung, S., Lawrence, D. A., Marsters, S. A., et al. (1999). Safety and Antitumor Activity of Recombinant Soluble Apo2 Ligand. J. Clin. Invest. 104, 155-162. doi:10.1172/jci6926

Barquero, A. A., Michelini, F. M., and Alché, L. E. (2006). 1-Cinnamoyl-3,11dihydroxymeliacarpin Is a Natural Bioactive Compound with Antiviral and Nuclear Factor-kappaB Modulating Properties. Biochem. Biophys. Res. Commun. 344, 955-962. doi:10.1016/j.bbrc.2006.03.226

Blaustein, R. O., Germann, W. J., Finkelstein, A., and DasGupta, B. R. (1987). The N-Terminal Half of the Heavy Chain of Botulinum Type A Neurotoxin Forms Channels in Planar Phospholipid Bilayers. FEBS Lett. 226, 115-120. doi:10.1016/0014-5793(87)80562-8

Bohnenstengel, F. I., Wray, V., Witte, L., Srivastava, R. P., and Proksch, P. (1999). Insecticidal Meliacarpins (C-Seco Limonoids) from Melia Azedarach. Phytochemistry 50, 977-982. doi:10.1016/s0031-9422(98)00644-x
LY contributed to conceptualization, writing-review and editing, and supervision.

\section{FUNDING}

This work is financially supported by the Program of Shanghai Municipal Commission of Health and Family Planning (ZY (2021-2023)-0215) and Innovation Team and Talents Cultivation Program of National Administration of Traditional Chinese Medicine. (ZYYCXTD-D-202004).

Burris, H. A. (2013). Overcoming Acquired Resistance to Anticancer Therapy: Focus on the PI3K/AKT/mTOR Pathway. Cancer Chemother. Pharmacol. 71, 829-842. doi:10.1007/s00280-012-2043-3

Campbell, K. J., and Tait, S. W. G. (2018). Targeting BCL-2 Regulated Apoptosis in Cancer. Open Biol. 8, 11. doi:10.1098/rsob.180002

Cao, L., Qu, D., Wang, H., Zhang, S., Jia, C., Shi, Z., et al. (2016). Toosendanin Exerts an Anti-cancer Effect in Glioblastoma by Inducing Estrogen Receptor $\beta$ - and P53-Mediated Apoptosis. Int. J. Mol. Sci. 17. doi:10.3390/ijms17111928

Carpinella, M. C., Defago, M. T., Valladares, G., and Palacios, S. M. (2003). Antifeedant and Insecticide Properties of a Limonoid from Melia Azedarach (Meliaceae) with Potential Use for Pest Management. J. Agric. Food Chem. 51, 369-374. doi:10.1021/jf025811w

Chen, L., Zhang, J. X., Wang, B., Mu, S. Z., and Hao, X. J. (2014). Triterpenoids with Anti-tobacco Mosaic Virus Activities from Melia Toosendan. Fitoterapia 97, 204-210. doi:10.1016/j.fitote.2014.06.010

Chen, T. X., Cheng, X. Y., Wang, Y., and Yin, W. (2018). Toosendanin Inhibits Adipogenesis by Activating Wnt/ $\beta$-Catenin Signaling. Sci. Rep. 8, 4626. doi:10.1038/s41598-018-22873-x

Chinese Pharmacopoeia Commission (2020). Pharmacopoeia of the People's republic of China[M]. Beijing, China: China Medical Science and Technology Press, p44-44.

D'Ambrosio, M., and Guerriero, A. (2002). Degraded Limonoids from Melia Azedarach and Biogenetic Implications. Phytochemistry 60, 419-424. doi:10.1016/s0031-9422(02)00107-3

Dong, S. H., Zhang, C. R., He, X. F., Liu, H. B., Wu, Y., and Yue, J. M. (2010). Mesendanins A-J, Limonoids from the Leaves and Twigs of Melia Toosendan. J. Nat. Prod. 73, 1344-1349. doi:10.1021/np100150n 
Druckova, A., Mernaugh, R. L., Ham, A. J., and Marnett, L. J. (2007). Identification of the Protein Targets of the Reactive Metabolite of Teucrin A In Vivo in the Rat. Chem. Res. Toxicol. 20, 1393-1408. doi:10.1021/tx7001405

Estaquier, J., Vallette, F., Vayssiere, J.-L., and Mignotte, B. (2012). "The Mitochondrial Pathways of Apoptosis," in Advances in Mitochondrial Medicine. Editors R. Scatena, P. Bottoni, and B. Giardina (Berlin: SpringerVerlag Berlin), 157-183. doi:10.1007/978-94-007-2869-1_7

Fan, H., Chen, W., Zhu, J., Zhang, J., and Peng, S. (2019). Toosendanin Alleviates Dextran Sulfate Sodium-Induced Colitis by Inhibiting M1 Macrophage Polarization and Regulating NLRP3 Inflammasome and Nrf2/HO-1 Signaling. Int. Immunopharmacol. 76, 105909. doi:10.1016/ j.intimp.2019.105909

Fiandalo, M. V., and Kyprianou, N. (2012). Caspase Control: Protagonists of Cancer Cell Apoptosis. Exp. Oncol. 34, 165-175.

Friesen, C., Fulda, S., and Debatin, K. M. (1997). Deficient Activation of the CD95 (APO-1/Fas) System in Drug-Resistant Cells. Leukemia 11, 1833-1841. doi:10.1038/sj.leu.2400827

Gao, T., Xie, A., Liu, X., Zhan, H., Zeng, J., Dai, M., et al. (2019). Toosendanin Induces the Apoptosis of Human Ewing's Sarcoma Cells via the Mitochondrial Apoptotic Pathway. Mol. Med. Rep. 20, 135-140. doi:10.3892/mmr.2019.10224

Goerlich, B. (1960). Chemical Assay of the Glycosides with Cardiac Effect in Scilla Maritima 1., Var. alba. Arzneimittelforschung 10, 770-774.

He, Y., Wang, J., Liu, X., Zhang, L., Yi, G., Li, C., et al. (2010). Toosendanin Inhibits Hepatocellular Carcinoma Cells by Inducing Mitochondria-dependent Apoptosis. Planta Med. 76, 1447-1453. doi:10.1055/s-0029-1240902

Holt, M. P., and Ju, C. (2006). Mechanisms of Drug-Induced Liver Injury. AAPS J. 8, E48-E54. doi:10.1208/aapsj080106

Hu, J.-F., Fan, H., Wang, L.-J., Wu, S.-B., and Zhao, Y. (2011). Limonoids from the Fruits of Melia Toosendan. Phytochemistry Lett. 4, 292-297. doi:10.1016/ j.phytol.2011.05.003

Hu, Q., Huang, F., and Shi, Y. (1997). Inhibition of Toosendanin on the Delayed Rectifier Potassium Current in Neuroblastoma X Glioma NG108-15 Cells. Brain Res. 751, 47-53. doi:10.1016/s0006-8993(96)01389-3

Hu, Y., Heng, L., Xu, R., Li, J., Wei, S., Xu, D., et al. (2018). Meliacarpinin-Type Limonoids from the Bark of Melia Toosendan. Molecules 23. doi:10.3390/ molecules 23102590

Huang, R. C., Okamura, H., Iwagawa, T., and Nakatani, M. (1994). The Structures of Azedarachins, Limonoid Antifeedants from ChineseMelia azedarachLinn. Bcsj 67, 2468-2472. doi:10.1246/bcsj.67.2468

Huang, R. C., Tadera, K., Yagi, F., Minami, Y., Okamura, H., Iwagawa, T., et al. (1996). Limonoids from Melia Azedarach. Phytochemistry 43, 581-583. doi:10.1016/0031-9422(96)00353-6

Huang, Y., Liu, J., Pang, T., and Li, L. (2017). Growth Inhibitory and Antifeedant Effects of Sublethal Concentrations of Toosendanin on the Rotifer Brachionus plicatilis. Biomass and Bioenergy 99, 31-37. doi:10.1016/j.biombioe.2017.02.013

Humeau, Y., Doussau, F., Grant, N. J., and Poulain, B. (2000). How Botulinum and Tetanus Neurotoxins Block Neurotransmitter Release. Biochimie 82, 427-446. doi:10.1016/s0300-9084(00)00216-9

Jafri, M. A., Al-Qahtani, M. H., and Shay, J. W. (2017). Role of miRNAs in Human Cancer Metastasis: Implications for Therapeutic Intervention. Semin. Cancer Biol. 44, 117-131. doi:10.1016/j.semcancer.2017.02.004

Janda, K. D. (2008). Small Molecule Therapeutic Approaches for the Treatment of Botulinum Neurotoxins A and B Intoxication. Toxicon 51, 13. doi:10.1016/ j.toxicon.2008.04.040

Jaoko, V., Nji Tizi Taning, C., Backx, S., Mulatya, J., Van den Abeele, J., Magomere, T., et al. (2020). The Phytochemical Composition of Melia Volkensii and its Potential for Insect Pest Management. Plants (Basel) 9. doi:10.3390/ plants9020143

Jin, Y., Huang, Z. L., Li, L., Yang, Y., Wang, C. H., Wang, Z. T., et al. (2019b). Quercetin Attenuates Toosendanin-Induced Hepatotoxicity through Inducing the Nrf2/GCL/GSH Antioxidant Signaling Pathway. Acta Pharmacol. Sin. 40, 75-85. doi:10.1038/s41401-018-0024-8

Jin, Y. H., Kwon, S., Choi, J. G., Cho, W. K., Lee, B., and Ma, J. Y. (2019a). Toosendanin from Melia Fructus Suppresses Influenza A Virus Infection by Altering Nuclear Localization of Viral Polymerase PA Protein. Front. Pharmacol. 10, 1025. doi:10.3389/fphar.2019.01025

Ju, J., Qi, Z., Cai, X., Cao, P., Huang, Y., Wang, S., et al. (2012). The Apoptotic Effects of Toosendanin Are Partially Mediated by Activation of
Deoxycytidine Kinase in HL-60 Cells. Plos One 7, e52536. doi:10.1371/ journal.pone. 0052536

Ju, J., Qi, Z., Cai, X., Cao, P., Liu, N., Wang, S., et al. (2013). Toosendanin Induces Apoptosis through Suppression of JNK Signaling Pathway in HL-60 Cells. Toxicol. Vitro 27, 232-238. doi:10.1016/j.tiv.2012.09.013

Kai, W., Yating, S., Lin, M., Kaiyong, Y., Baojin, H., Wu, Y., et al. (2018). Natural Product Toosendanin Reverses the Resistance of Human Breast Cancer Cells to Adriamycin as a Novel PI3K Inhibitor. Biochem. Pharmacol. 152, 153-164. doi:10.1016/j.bcp.2018.03.022

Li, H., Zhang, J., Ma, T., Li, C., Ma, Z., and Zhang, X. (2020a). Acting Target of Toosendanin Locates in the Midgut Epithelium Cells of Mythimna Separate Walker Larvae (Lepidoptera: Noctuidae). Ecotoxicol. Environ. Saf. 201, 110828. doi:10.1016/j.ecoenv.2020.110828

Li, M. F., and Shi, Y. L. (2005). The Long-Term Effect of Toosendanin on Current through Nifedipine-Sensitive Ca2+ Channels in NG108-15 Cells. Toxicon 45, 53-60. doi:10.1016/j.toxicon.2004.09.010

Li, M. F., and Shi, Y. L. (2006). Toosendanin Interferes with Pore Formation of Botulinum Toxin Type A in PC12 Cell Membrane. Acta Pharmacol. Sin. 27, 66-70. doi:10.1111/j.1745-7254.2006.00236.x

Li, M. F., and Shi, Y. L. (2004). Toosendanin, a Triterpenoid Derivative, Acts as a Novel Agonist of L-type Ca2+ Channels in Neonatal Rat Ventricular Cells. Eur. J. Pharmacol. 501, 71-78. doi:10.1016/j.ejphar.2004.08.027

Li, P. Z., and Sun, G. Z. (1983). Antagonistic Effect of Toosendanin to Botulinum Toxin on Neuromuscular Preparations of Mice. Acta Physiol. Sinica. 4, $480-483$.

Li, S., Li, Y., Xu, R., Kong, L. Y., and Luo, J. (2020b). New Meliacarpin-type (C-Seco) and C-Ring Intact Limonoids from the Fruits of Melia Toosendan. Fitoterapia 144, 104605. doi:10.1016/j.fitote.2020.104605

Li, S., Li, Y., Xu, R., Kong, L. Y., Luo, J., Zhu, X. M., et al. (2020). New Meliacarpin-type (C-Seco) and C-Ring Intact Limonoids from the Fruits of Melia Toosendan. Fitoterapia 144, 104605-104622. doi:10.1016/ j.fitote.2020.104605

Li, X., You, M., Liu, Y. J., Ma, L., Jin, P. P., Zhou, R., et al. (2017). Reversal of the Apoptotic Resistance of Non-small-cell Lung Carcinoma towards TRAIL by Natural Product Toosendanin. Sci. Rep. 7, 42748. doi:10.1038/srep42748

Li, Y. Y., Jin, L. T., Lin, J. T., Ding, Y. M., and Yao, S. H. (2018a). Effect of Toosendanin on the Apoptosis of Human Ovarian Cancer Cells through Mitochondrial Pathway. Chin. Pharm. J. 2, 109-113. doi:10.11669/ cpj.2018.02.007

Li, Y. Y., Shao, X. Y., Jin, L. T., Li, Q. F., and Chen, X. M. (2019). Apoptosis of Ovarian Cancer Cells Induced by Toosendanin through Fas/FasL Signaling Pathway. Chin. J. Integr. Trad. West. Med. 9, 1089-1094. doi:10.7661/ j.cjim.20190729.089

Li, Y. Y., Zhang, K. N., Cai, J. W., Lin, J. T., and Shao, X. Y. (2018b). Effect of Toosendanin on Invasion and Migration of Human Ovarian Cancer Cells. Chin. J. Pathophysiol. 1, 70-74. doi:10.3969/j.issn.1000-4718.2018.01.012

Li-Weber, M. (2013). Targeting Apoptosis Pathways in Cancer by Chinese Medicine. Cancer Lett. 332, 304-312. doi:10.1016/j.canlet.2010.07.015

Lian, X., Zhang, X., Wang, F., Wang, X., Xue, Z., and Qi, X. (2020). Characterization of a 2,3-oxidosqualene Cyclase in the Toosendanin Biosynthetic Pathway of Melia Toosendan. Physiol. Plant 170, 528-536. doi:10.1111/ppl.13189

Liu, H., Liu, Y., Bian, Z., Zhang, J., Zhang, R., Chen, X., et al. (2019). Correction to: Circular RNA YAP1 Inhibits the Proliferation and Invasion of Gastric Cancer Cells by Regulating the miR-367-5p/p27 Kip1 axis. Mol. Cancer 18, 117. doi:10.1186/s12943-019-1045-8

Liu, H. B., Zhang, C. R., Dong, S. H., Dong, L., Wu, Y., and Yue, J. M. (2011). Limonoids and Triterpenoids from the Seeds of Melia Azedarach. Chem. Pharm. Bull. (Tokyo) 59, 1003-1007. doi:10.1248/cpb.59.1003

Liu, S. C., Tang, W. Z., Ma, T., and Yao, Q. Q. (2010). Review on Studies of the Chemical Constituents and Pharmcological Activities of Melia L. Qilu Pharm. Aff. 5, 290-293. doi:10.3969/j.issn.1672-7738.2010.05.017

Liu, X. L., Wang, H., Zhang, L., Wang, Y. L., Wang, J., Wang, P., et al. (2016). Anticancer effects of crude extract from Melia toosendan Sieb. et Zucc on hepatocellular carcinoma In Vitro and In Vivo. Chin. J. Integr. Med. 22, 362-369. doi:10.1007/s11655-015-2084-7

Lu, X., Ji, C., Tong, W., Lian, X., Wu, Y., Fan, X., et al. (2016). Integrated Analysis of microRNA and mRNA Expression Profiles Highlights the Complex and 
Dynamic Behavior of Toosendanin-Induced Liver Injury in Mice. Sci. Rep. 6, 34225. doi: $10.1038 /$ srep34225

Luo, W., Liu, X., Sun, W., Lu, J. J., Wang, Y., and Chen, X. (2018). Toosendanin, a Natural Product, Inhibited TGF-B1-Induced Epithelial-Mesenchymal Transition through ERK/Snail Pathway. Phytother. Res. 32, 2009-2020. doi:10.1002/ptr.6132

Ma, Z., Gulia-Nuss, M., Zhang, X., and Brown, M. R. (2013). Effects of the Botanical Insecticide, Toosendanin, on Blood Digestion and Egg Production by Female Aedes aegypti (Diptera: Culicidae): Topical Application and Ingestion. J. Med. Entomol. 50, 112-121. doi:10.1603/me12119

Madyastha, K. M., and Venkatakrishnan, K. (2000). Structural Flexibility in the Biocatalyst-Mediated Functionalization of Ring 'A' in Salannin, a Tetranortriterpene from Azadirachta indica. J. Chem. Soc. Perkin Trans. 1 118, 3055-3062. doi:10.1039/b004260i

Nakai, Y., Pellett, S., Tepp, W. H., Johnson, E. A., and Janda, K. D. (2010). Toosendanin: Synthesis of the AB-Ring and Investigations of its Antibotulinum Properties (Part II). Bioorg. Med. Chem. 18, 1280-1287. doi:10.1016/j.bmc.2009.12.030

Nakai, Y., Tepp, W. H., Dickerson, T. J., Johnson, E. A., and Janda, K. D. (2009). Function-oriented Synthesis Applied to the Anti-botulinum Natural Product Toosendanin. Bioorg. Med. Chem. 17, 1152-1157. doi:10.1016/j.bmc.2008.12.042

Nakatani, M., Chun Huang, R., Okamura, H., Naoki, H., and Iwagawa, T. (1994). Limonoid Antifeedants from Chinese Melia Azedarach. Phytochemistry 36, 39-41. doi:10.1016/s0031-9422(00)97008-0

Nakatani, M., Fukuman, Y., Sakumoto, T., Yamashita, N., Okamura, H., and Iwagawa, T. (2000). Nimbolinins, C-Seco Limonoids from the Fruits of Melia Toosendan. Heterocycles 53, 689. doi:10.3987/com-99-8768

Nakatani, M., Huang, R. C., Okamura, H., and Iwagawa, T. (1993). The Structure of a New Antifeeding Meliacarpinin from ChinesMelia azedarachL. Chem. Lett. 22, 2125-2128. doi:10.1246/cl.1993.2125

Nakatani, M. (1999). Limonoids from Melia Toosendan (Meliaceae) and Their Antifeedant Activity. Heterocycles 50, 595-609. doi:10.3987/rev-98-sr(h)5

Nakatani, M., Shimokoro, M., Zhou, J.-B., Okamura, H., Iwagawa, T., Tadera, K., et al. (1999). Limonoids from Melia Toosendan. Phytochemistry 52, 709-714. doi:10.1016/s0031-9422(99)00332-5

Nakatani, M., Zhou, J.-B., Nakayama, N., Okamura, H., and Iwagawa, T. (1996). Nimbolidins C-E, Limonoid Antifeedants from Melia Toosendan. Phytochemistry 41, 739-743. doi:10.1016/0031-9422(95)00696-6

Ochi, M., Kotsuki, H., Ido, M., Nakai, H., Shiro, M., and Tokoroyama, T. (1979). The Structures of Ohchinolide a and B, Two New Limonoids Frommelia Azedarachlinn.Var. Japonicamakino. Chem. Lett. 8, 1137-1140. doi:10.1246/cl.1979.1137

Ola, M. S., Nawaz, M., and Ahsan, H. (2011). Role of Bcl-2 Family Proteins and Caspases in the Regulation of Apoptosis. Mol. Cell. Biochem. 351, 41-58. doi:10.1007/s11010-010-0709-x

Orrenius, S., Zhivotovsky, B., and Nicotera, P. (2003). Regulation of Cell Death: the Calcium-Apoptosis Link. Nat. Rev. Mol. Cel Biol 4, 552-565. doi:10.1038/ nrm1150

Otto, T., and Sicinski, P. (2017). Cell Cycle Proteins as Promising Targets in Cancer Therapy. Nat. Rev. Cancer 17, 93-115. doi:10.1038/nrc.2016.138

Pan, X., Matsumoto, M., Nakamura, Y., Kikuchi, T., Zhang, J., Ukiya, M., et al. (2014a). Three New and Other Limonoids from the Hexane Extract of Melia Azedarach Fruits and Their Cytotoxic Activities. Chem. Biodivers. 11, 987-1000. doi:10.1002/cbdv.201400052

Pan, X., Matsumoto, M., Nishimoto, Y., Ogihara, E., Zhang, J., Ukiya, M., et al. (2014b). Cytotoxic and Nitric Oxide Production-Inhibitory Activities of Limonoids and Other Compounds from the Leaves and Bark of Melia Azedarach. Chem. Biodivers. 11, 1121-1139. doi:10.1002/cbdv.201400190

Park, S., Nhiem, N. X., Subedi, L., Oh, I., Kim, J. Y., Kim, S. Y., et al. (2020). Isolation of Bioactive Limonoids from the Fruits of Melia Azedarach. J. Asian Nat. Prod. Res. 22, 830-838. doi:10.1080/10286020.2019.1666826

Pei, Z., Fu, W., and Wang, G. (2017). A Natural Product Toosendanin Inhibits Epithelial-Mesenchymal Transition and Tumor Growth in Pancreatic Cancer via Deactivating Akt/mTOR Signaling. Biochem. Biophys. Res. Commun. 493, 455-460. doi:10.1016/j.bbrc.2017.08.170

Qiu, L., Heng, L., Xu, R., Luo, J., and Li, Y. (2019). Two New Nimbolinin- and Trichilin-Class Limonoids Isolated from the Fruits of Melia Azedarach. Chin. J. Nat. Med. 17, 227-230. doi:10.1016/s1875-5364(19)30025-1
Rizzuto, R., Pinton, P., Ferrari, D., Chami, M., Szabadkai, G., Magalhães, P. J., et al. (2003). Calcium and Apoptosis: Facts and Hypotheses. Oncogene 22, 8619-8627. doi:10.1038/sj.onc.1207105

Rogers, L. L., Zeng, L., Kozlowski, J. F., Shimada, H., Alali, F. Q., Johnson, H. A., et al. (1998a). New Bioactive Triterpenoids from Melia Volkensii. J. Nat. Prod. 61, 64-70. doi:10.1021/np9704009

Rogers, L. L., Zeng, L., and McLaughlin, J. L. (1998b). Volkensinin: A New Limonoid from Melia Volkensii. Tetrahedron Lett. 39, 4623-4626. doi:10.1016/s0040-4039(98)00854-5

Rossetto, O., Pirazzini, M., and Montecucco, C. (2014). Botulinum Neurotoxins: Genetic, Structural and Mechanistic Insights. Nat. Rev. Microbiol. 12, 535-549. doi:10.1038/nrmicro3295

Sachdeva, M., and Mo, Y. Y. (2010). MicroRNA-145 Suppresses Cell Invasion and Metastasis by Directly Targeting Mucin 1. Cancer Res. 70, 378-387. doi:10.1158/0008-5472.can-09-2021

Saleem, S., Muhammad, G., Hussain, M. A., and Bukhari, S. N. A. (2018). A Comprehensive Review of Phytochemical Profile, Bioactives for Pharmaceuticals, and Pharmacological Attributes of Azadirachta indica. Phytother. Res. 32, 1241-1272. doi:10.1002/ptr.6076

Shao, S., Li, S., Liu, C., Zhang, W., Zhang, Z., Zhu, S., et al. (2020). Toosendanin Induces Apoptosis of MKN45 Human Gastric Cancer Cells Partly through miR23a3pmediated Downregulation of BCL2. Mol. Med. Rep. 22, 1793-1802. doi:10.3892/mmr.2020.11263

Shen, L. Q., Peng, F., Cai, J. N., Liu, J. Y., Hao, L. L., Feng, Y. L., et al. (2014). Fingerprint Analysis of Limonoids in Fructus Toosendan by HPLC-ELSD. Chin. J. Pharm. Anal. 8, 1431-1434. doi:10.16155/j.0254-1793.2014.08.007

Shi, Y. L., and Li, M. F. (2007). Biological Effects of Toosendanin, a Triterpenoid Extracted from Chinese Traditional Medicine. Prog. Neurobiol. 82, 1-10. doi:10.1016/j.pneurobio.2007.02.002

Shi, Y. L., Wang, W. P., Yan, S. C., and Xu, K. (1982). Effects of Calcium Ions and Nerve Impulses on Changes in Miniature End-Plate Potential Frequency Produced by Toosendanin. Acta Physiol. Sinica. 3, 304-309.

Shih, Y. L., and Hsu, K. (1983). Anti-botulismic Effect of Toosendanin and its Facilitatory Action on Miniature End-Plate Potentials. Jpn. J. Physiol. 33, 677-680. doi:10.2170/jjphysiol.33.677

Siddiqui, W. A., Ahad, A., and Ahsan, H. (2015). The Mystery of BCL2 Family: Bcl2 Proteins and Apoptosis: an Update. Arch. Toxicol. 89, 289-317. doi:10.1007/ s00204-014-1448-7

Singh, N., Hassan, A., and Bose, K. (2016). Molecular Basis of Death Effector Domain Chain Assembly and its Role in Caspase-8 Activation. FASEB J. 30, 186-200. doi:10.1096/fj.15-272997

Su, G. X., and Liang, X. T. (1980). A Correction of the Structure of Chuanliansu. Acta Chim. Sinica. 2, 196-198.

Su, S., Shen, L., Zhang, Y., Liu, J., Cai, J., Hao, L., et al. (2013). Characterization of Tautomeric Limonoids from the Fruits of Melia Toosendan. Phytochemistry Lett. 6, 418-424. doi:10.1016/j.phytol.2013.05.006

Su, Z.-S., Yang, S.-P., Zhang, S., Dong, L., and Yue, J.-M. (2011). Meliarachins A-K: Eleven Limonoids from the Twigs and Leaves of Melia Azedarach. Hca 94, 1515-1526. doi:10.1002/hlca.201000444

Tada, K., Takido, M., and Kitanaka, S. (1999). Limonoids from Fruit of Melia Toosendan and Their Cytotoxic Activity. Phytochemistry 51, 787-791. doi:10.1016/s0031-9422(99)00115-6

Takeya, K., Qiao, Z. S., Hirobe, C., and Itokawa, H. (1996a). Cytotoxic Azadirachtin-type Limonoids from Melia Azedarach. Phytochemistry 42, 709-712. doi:10.1016/0031-9422(96)00044-1

Takeya, K., Quio, Z. S., Hirobe, C., and Itokawa, H. (1996b). Cytotoxic Trichilintype Limonoids from Melia Azedarach. Bioorg. Med. Chem. 4, 1355-1359. doi:10.1016/0968-0896(96)00128-9

Tan, Q. G., and Luo, X. D. (2011). Meliaceous Limonoids: Chemistry and Biological Activities. Chem. Rev. 111, 7437-7522. doi:10.1021/cr9004023

Tang, M. Z., Wang, Z. F., and Shi, Y. L. (2004). Involvement of Cytochrome C Release and Caspase Activation in Toosendanin-Induced PC12 Cell Apoptosis. Toxicology 201, 31-38. doi:10.1016/j.tox.2004.03.023

Tao, L., Zhang, F., Hao, L., Wu, J., Jia, J., Liu, J. Y., et al. (2014). 1-O-tigloyl-1-Odeacetyl-nimbolinin B Inhibits LPS-Stimulated Inflammatory Responses by Suppressing NF-kB and JNK Activation in Microglia Cells. J. Pharmacol. Sci. 125, 364-374. doi:10.1254/jphs.14025FP 
Taylor, D. A. H. (1984). The Chemistry of the Limonoids from Meliaceae. Prog. Chem. Org. Nat. Prod. 45, 1-102. doi:10.1007/978-3-7091-8717-3_1

Tummers, B., and Green, D. R. (2017). Caspase-8: Regulating Life and Death. Immunol. Rev. 277 (1), 76-89. doi:10.1111/imr.12541

Wajant, H. (2002). The Fas Signaling Pathway: More Than a Paradigm. Science 296, 1635-1636. doi:10.1126/science.1071553

Wang, G., Feng, C. C., Chu, S. J., Zhang, R., Lu, Y. M., Zhu, J. S., et al. (2015). Toosendanin Inhibits Growth and Induces Apoptosis in Colorectal Cancer Cells through Suppression of AKT/GSK-3 $/ \beta$-catenin Pathway. Int. J. Oncol. 47, 1767-1774. doi:10.3892/ijo.2015.3157

Wang, G., Huang, Y.-X., Zhang, R., Hou, L.-D., Liu, H., Chen, X.-Y., et al. (2017). Toosendanin Suppresses Oncogenic Phenotypes of Human Gastric Carcinoma SGC-7901 Cells Partly via miR-200a-Mediated Downregulation of $\beta$-catenin Pathway. Int. J. Oncol. 51, 1563-1573. doi:10.3892/ijo.2017.4139

Wang, H., Dong, H. Y., He, Q. M., Liang, J. L., Zhao, T., and Zhou, L. (2020a). Characterization of Limonoids Isolated from the Fruits of Melia Toosendan and Their Antifeedant Activity against Pieris Rapae. Chem. Biodivers. 17, e1900674. doi:10.1002/cbdv.201900674

Wang, H., Wen, C., Chen, S., Wang, F., He, L., Li, W., et al. (2020b). Toosendanininduced Apoptosis in Colorectal Cancer Cells Is Associated with the $\kappa$-opioid Receptor/ $\beta$-Catenin Signaling axis. Biochem. Pharmacol. 177, 114014. doi:10.1016/j.bcp.2020.114014

Wang, Q., Wang, Z., Hou, G., and Huang, P. (2020c). Toosendanin Suppresses Glioma Progression Property and Induces Apoptosis by Regulating miR608/Notch Axis. Cancer Manag. Res. 12, 3419-3431. doi:10.2147/ cmar.s240268

Wang, X., Wang, C., and Wang, Z. (2013). Determination of Toosendanin in Rat Plasma by Ultra-performance Liquid Chromatography-Electrospray Ionization-Mass Spectrometry and its Application in a Pharmacokinetic Study. Biomed. Chromatogr. 27, 222-227. doi:10.1002/bmc.2779

Watanabe, T., Sakamoto, N., Nakagawa, M., Kakinuma, S., Itsui, Y., NishimuraSakurai, Y., et al. (2011). Inhibitory Effect of a Triterpenoid Compound, with or without Alpha Interferon, on Hepatitis C Virus Infection. Antimicrob. Agents Chemother. 55, 2537-2545. doi:10.1128/aac.01780-10

Wender, P. A. (2013). Toward the Ideal Synthesis and Transformative Therapies: the Roles of Step Economy and Function Oriented Synthesis. Tetrahedron 69 (36), 7529-7550. doi:10.1016/j.tet.2013.06.004

Whitfield, M. L., George, L. K., Grant, G. D., and Perou, C. M. (2006). Common Markers of Proliferation. Nat. Rev. Cancer 6, 99-106. doi: $10.1038 / \mathrm{nrc1} 1802$

Wu, J. L., Leung, E. L., Zhou, H., Liu, L., and Li, N. (2013). Metabolite Analysis of Toosendanin by an Ultra-high Performance Liquid ChromatographyQuadrupole-Time of Flight Mass Spectrometry Technique. Molecules 18, 12144-12153. doi:10.3390/molecules 181012144

Xie, F., Zhang, M., Zhang, C. F., Wang, Z. T., Yu, B. Y., and Kou, J. P. (2008). Antiinflammatory and Analgesic Activities of Ethanolic Extract and Two Limonoids from Melia Toosendan Fruit. J. Ethnopharmacol. 117, 463-466. doi:10.1016/ j.jep.2008.02.025

Xie, Y. S., Fields, P. G., Isman, M. B., Chen, W. K., and Zhang, X. (1995). Insecticidal Activity of Melia Toosendan Extracts and Toosendanin against Three Stored-Product Insects. J. Stored Prod. Res. 31, 259-265. doi:10.1016/ 0022-474x (95)00003-p

Xiong, C. S. (1985). The Interaction between Toosendanin and Botulinum Toxin at the Neuromuscular junction, an Ultrastructure Observation. Acta Pharm. Sin. 7, 495-499.

Xu, H., and Zhang, J. L. (2011). Natural Products-Based Insecticidal Agents 9. Design, Semisynthesis and Insecticidal Activity of 28-acyloxy Derivatives of Toosendanin against Mythimna Separata Walker In Vivo. Bioorg. Med. Chem. Lett. 21, 1974-1977. doi:10.1016/j.bmcl.2011.02.031

Xu, R., Zhang, L., and Liu, J. (2019). The Natural Triterpenoid Toosendanin as a Potential Control Agent of the Ciliate Stylonychia mytilus in Microalgal Cultures. J. Appl. Phycol. 31, 41-48. doi:10.1007/s10811-018-1522-2

Yan, X., Zhuo, Y., Bian, X., Li, J., Zhang, Y., Ma, L., et al. (2019). Integrated Proteomics, Biological Functional Assessments, and Metabolomics Reveal Toosendanin-Induced Hepatic Energy Metabolic Disorders. Chem. Res. Toxicol. 32, 668-680. doi:10.1021/acs.chemrestox.8b00350

Yang, F., Li, L., Yang, R., Wei, M., Sheng, Y., and Ji, L. (2019). Identification of Serum microRNAs as Potential Toxicological Biomarkers for Toosendanin-
Induced Liver Injury in Mice. Phytomedicine 58, 152867. doi:10.1016/ j.phymed.2019.152867

Yu, J., Deng, P., Zhong, D., and Chen, X. (2014). Identification of Amino Acid and Glutathione N-Conjugates of Toosendanin: Bioactivation of the Furan Ring Mediated by CYP3A4. Chem. Res. Toxicol. 27, 1598-1609. doi:10.1021/ tx5002145

Yu, J., Zhang, R., Zhang, T., Zhao, J., Zhang, Y., Wang, Q., et al. (2020). Determination of Toosendanin and Trans-anethole in Fructus Meliae Toosendan and Fructus Foeniculi by HPLC-MS/MS and GC-MS/MS in Rat Plasma and Their Potential Herb-Herb Interactions. Biomed. Chromatogr. 34, e4837. doi:10.1002/bmc.4837

Yuan, C. M., Zhang, Y., Tang, G. H., Li, Y., He, H. P., Li, S. F., et al. (2013). Cytotoxic Limonoids from Melia Azedarach. Planta Med. 79, 163-168. doi:10.1055/s-0032-1328069

Zeng, L., Gu, Z.-m., Fang, X.-p., Fanwick, P. E., Chang, C.-j., Smith, D. L., et al. (1995a). Two New Bioactive Triterpenoids from Melia Volkensii (Meliaceae). Tetrahedron 51, 2477-2488. doi:10.1016/0040-4020(95)00018-4

Zeng, L., Gu, Z. M., Fanwick, P. E., Chang, C. J., Smith, D. L., and McLaughlin, J. L. (1995b). Additional Bioactive Triterpenoids from Melia-Volkensii (Meliaceae). Heterocycles 41, 741-752.

Zhang, B., Wang, Z. F., Tang, M. Z., and Shi, Y. L. (2005a). Growth Inhibition and Apoptosis-Induced Effect on Human Cancer Cells of Toosendanin, a Triterpenoid Derivative from Chinese Traditional Medicine. Invest. New Drugs 23, 547-553. doi:10.1007/s10637-005-0909-5

Zhang, J. L., Shi, W. Y., Zhong, W., Ma, A. T., Wang, X. D., Zhao, Y. T., et al. (2010a). Effects of Toosendanin on Pregnancy and Uterine Immunity Alterations in Mice. Am. J. Chin. Med. 38, 319-328. doi:10.1142/s0192415x10007877

Zhang, Q., Li, J. K., Ge, R., Liang, J. Y., Li, Q. S., and Min, Z. D. (2013). Novel NGFPotentiating Limonoids from the Fruits of Melia Toosendan. Fitoterapia 90, 192-198. doi:10.1016/j.fitote.2013.07.019

Zhang, Q., Li, Q. S., Liang, J. Y., and Min, Z. D. (2010d). Limonoids from Fruits of Melia Toosendan. Yao Xиe Xиe Bao 45, 475-478. doi:10.16438/j.05134870.2010.04.006

Zhang, Q., Shi, Y., Liu, X. T., Liang, J. Y., Ip, N. Y., and Min, Z. D. (2007). Minor Limonoids from Melia Toosendan and Their Antibacterial Activity. Planta Med. 73 (12), 1298-1303. doi:10.1055/s-2007-981618

Zhang, Q., Zheng, Q. H., Liang, J. Y., Li, Q. S., and Min, Z. D. (2016). Two New Limonoids Isolated from the Fuits of Melia Toosendan. Chin. J. Nat. Med. 14 692-696. doi:10.1016/s1875-5364(16)30082-6

Zhang, Q., Zheng, Q. H., Sang, Y. S., Sung, H. H., and Min, Z. D. (2018). New Limonoids Isolated from the Bark of Melia Toosendan. Chin. J. Nat. Med. 16, 946-950. doi:10.1016/S1875-5364(18)30136-5

Zhang, Q., Liang, J. Y., Li, Q. S., and Da Min, Z. (2010b). New Limonoids from the Fruits of Melia Toosendan. Chin. Chem. Lett. 21, 838-841. doi:10.1016/ j.cclet.2010.02.018

Zhang, W. M., Liu, J. Q., Peng, X. R., Wan, L. S., Zhang, Z. R., Li, Z. R., et al. (2014). Triterpenoids and Sterols from the Leaves and Twigs of Melia Azedarach. Nat. Prod. Bioprospect. 4, 157-162. doi:10.1007/s13659-014-0019-1

Zhang, X. F., Wang, J. H., Zhang, S. F., Liu, Y., Fan, L. C., and Shi, X. Y. (2005b). Research of Embryotoxicity of Toosendanin in Kunming Mice. Acta Vet. Zootechnica Sinica 3, 301-305. doi:10.3321/j.issn:0366-6964.2005.03.020

Zhang, X., and Zhao, S. H. (1992a). Effect of Toosendanin on Several Enzyme Systems of the Cabbage Worm Pieris Rapae L. Acta Entomol. Sinica. 2, 171-177.

Zhang, X., and Zhao, S. H. (1992b). Effect of Toosendanin on the Respiration and Other Physiological Parameters of the Imported Cabbage Worm (Pieris Rapae L). J. South. China Agr. Univ. 2, 5-11.

Zhang, X., and Zhao, S. H. (1991). Studies on the Histopathology of the Midgut of Cabbageworm Pieris Rapae L. Caused by Toosendanin. Acta Entomol. Sinica. 4, 501-502.

Zhang, Y., Qi, X., Gong, L., Li, Y., Liu, L., Xue, X., et al. (2008). Roles of Reactive Oxygen Species and MAP Kinases in the Primary Rat Hepatocytes Death Induced by Toosendanin. Toxicology 249, 62-68. doi:10.1016/j.tox.2008.04.005

Zhang, Y., Tang, C. P., Ke, C. Q., Li, X. Q., Xie, H., and Ye, Y. (2012). Limonoids from the Fruits of Melia Toosendan. Phytochemistry 73, 106-113. doi:10.1016/ j.phytochem.2011.10.001

Zhang, Y., Tang, C. P., Ke, C. Q., Yao, S., and Ye, Y. (2010c). Limonoids and Triterpenoids from the Stem Bark of Melia Toosendan. J. Nat. Prod. 73, 664-668. doi:10.1021/np900835k 
Zhao, L., Huo, C. H., Shen, L. R., Yang, Y., Zhang, Q., and Shi, Q. W. (2010). Chemical Constituents of Plants from the Genus Melia. Chem. Biodivers. 7, 839-859. doi:10.1002/cbdv.200900043

Zhao, Q., Song, Y., Feng, C., and Chen, H. (2012). Cytotoxic Tirucallane Triterpenoids from the Stem Bark of Melia Toosendan. Arch. Pharm. Res. 35, 1903-1907. doi:10.1007/s12272-012-1106-7

Zheng, M. D., Wang, N. D., Li, X. L., Yan, J., Tang, J. H., Zhao, X. H., et al. (2018). Toosendanin Mediates Cisplatin Sensitization through Targeting Annexin A4/ ATP7A in Non-small Cell Lung Cancer Cells. J. Nat. Med. 72, 724-733. doi:10.1007/s11418-018-1211-0

Zhong, C. C., Xie, J. X., Chen, S. F., and Liang, X. T. (1975). The Structure of Chuanliansu. Acta Chim. Sinica. 1, 35-47.

Zhou, C.-Y., Tang, H.-Y., Li, X., and Sang, Y.-S. (2009). Three New Limonoids fromMelia Toosendan. Hca 92, 1191-1197. doi:10.1002/hlca.200800428

Zhou, F., Ma, X. H., Li, Z. J., Li, W., Zheng, W. M., Wang, Z. B., et al. (2016). Four New Tirucallane Triterpenoids from the Fruits of Melia Azedarach and Their Cytotoxic Activities. Chem. Biodivers. 13, 1738-1746. doi:10.1002/cbdv.201600149

Zhou, H., Hamazaki, A., Fontana, J. D., Takahashi, H., Esumi, T., Wandscheer, C. B., et al. (2004). New Ring C-Seco Limonoids from Brazilian Melia Azedarach and Their Cytotoxic Activity. J. Nat. Prod. 67, 1544-1547. doi:10.1021/np040077r

Zhou, H., Hamazaki, A., Fontana, J. D., Takahashi, H., Wandscheer, C. B., and Fukuyama, Y. (2005). Cytotoxic Limonoids from Brazilian Melia Azedarach. Chem. Pharm. Bull. (Tokyo) 53, 1362-1365. doi:10.1248/cpb.53.1362

Zhou, J.-B., Minami, Y., Yagi, F., Tadera, K., and Nakatani, M. (1997). Ring C-Seco Limonoids from Melia Toosendan. Phytochemistry 46, 911-914. doi:10.1016/ s0031-9422(97)00378-6

Zhou, J.-B., Okamura, H., Iwagawa, T., and Nakatani, M. (1996). Limonoid Antifeedants from Melia Toosendan. Phytochemistry 41, 117-120. doi:10.1016/0031-9422(95)00558-7

Zhou, J. B., Tadera, K., Minami, Y., Yagi, F., Kurawaki, J., Takezaki, K., et al. (1998). New Limonoids from Melia Toosendan. Biosci. Biotechnol. Biochem. 62, 496-500. doi:10.1271/bbb.62.496
Zhou, J. Y., Wang, Z. F., Ren, X. M., Tang, M. Z., and Shi, Y. L. (2003). Antagonism of Botulinum Toxin Type A-Induced Cleavage of SNAP-25 in Rat Cerebral Synaptosome by Toosendanin. FEBS Lett. 555, 375-379. doi:10.1016/s00145793(03)01291-2

Zhou, Q., Wu, X., Wen, C., Wang, H., Wang, H., Liu, H., et al. (2018). Toosendanin Induces Caspase-dependent Apoptosis through the P38 MAPK Pathway in Human Gastric Cancer Cells. Biochem. Biophysical Res. Commun. 505, 261-266. doi:10.1016/j.bbrc.2018.09.093

Zhu, G. Y., Bai, L. P., Liu, L., and Jiang, Z. H. (2014). Limonoids from the Fruits of Melia Toosendan and Their NF-кB Modulating Activities. Phytochemistry 107, 175-181. doi:10.1016/j.phytochem.2014.08.009

Zou, J., Ye, H. J., He, X. Y., Yu, Y. X., XiaZhang, H. Q. L. S., Zhang, A. P., et al. (1985). The Therapeutic Effect of Orally Administrated Toosendanin on Human Botulism. Mil. Med. Sci. 37, 307-310.

Conflict of Interest: The authors declare that the research was conducted in the absence of any commercial or financial relationships that could be construed as a potential conflict of interest.

Publisher's Note: All claims expressed in this article are solely those of the authors and do not necessarily represent those of their affiliated organizations or those of the publisher, the editors, and the reviewers. Any product that may be evaluated in this article or claim that may be made by its manufacturer is not guaranteed or endorsed by the publisher.

Copyright (c) 2022 Fan, Fan, Wang and Yang. This is an open-access article distributed under the terms of the Creative Commons Attribution License (CC $B Y$ ). The use, distribution or reproduction in other forums is permitted, provided the original author(s) and the copyright owner(s) are credited and that the original publication in this journal is cited, in accordance with accepted academic practice. No use, distribution or reproduction is permitted which does not comply with these terms. 


\section{GLOSSARY}

Cyt C Cytochrome c

AIF Apoptosis-inducing factor

Caspase Cysteinyl aspartate-specific proteinase

Apaf-1 Apoptotic protease-activating factor-1

Bcl-2 B-cell lymphoma-2

PARP Poly-ADP-ribose polymerase

TNFR Tumor necrosis factor receptor

DR Death receptor

FADD Fas-associated death domain protein

DD Death domain

DED Death effector domain

DISC Death-inducing signaling complex

TRAIL Tumor necrosis factor (TNF)-related apoptosis-inducing ligand DR5 Death receptor 5

CHOP CCAAT/enhancer-binding protein homologous protein

ROS Reactive oxygen species

JNK c-Jun N-terminal kinase

miRNAs MicroRNAs

EMT Epithelial-mesenchymal transition

ECM Extracellular matrix

TGF- $\beta 1$ Transforming growth factor- $\beta 1$
NSCLC Non-small cell lung cancer

ADM Adriamycin

SAR Structure-activity relationships

DDS Dextran sulfate sodium

NLRP3 NLR family pyrin domain containing 3

NO Nitric oxide

TNF Tumor necrosis factor

iNOS Inducible nitric oxide synthase

COX-2 Cyclooxygenase

IL Interleukin

LPS Lipopolysaccharide

C/EBP- $\boldsymbol{\alpha}$ CCAAT/enhancer-binding proteins $\boldsymbol{\alpha}$

PPAR- $\gamma$ Peroxisome proliferator-activated receptor $\gamma$

HFD High-fat diet

$\boldsymbol{\alpha}$-IFN Alpha interferon

GSH Glutathione

ALT Alanine aminotransferase

AST Aspartate aminotransferase

TPI1 Triosephosphate isomerase 1

ENOA $\alpha$-Enolase

Keap1 Kelch-like ECH-associated protein-1 